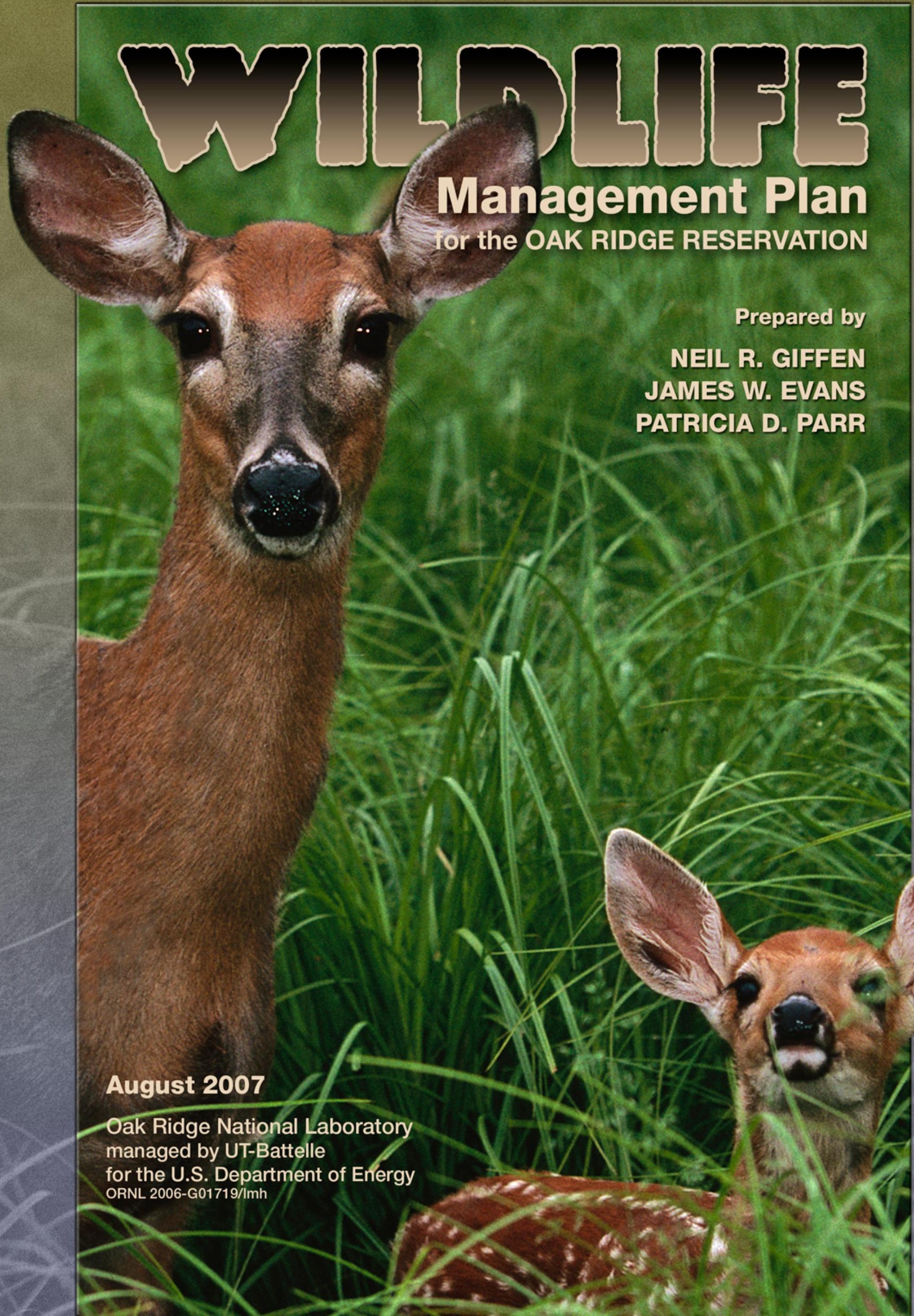




\section{DOCUMENT AVAILABILITY}

Reports produced after January 1, 1996, are generally available free via the U.S. Department of Energy (DOE) Information Bridge.

Web site http://www.osti.gov/bridge

Reports produced before January 1, 1996, may be purchased by members of the public from the following source.

National Technical Information Service

5285 Port Royal Road

Springfield, VA 22161

Telephone 703-605-6000 (1-800-553-6847)

TDD 703-487-4639

Fax 703-605-6900

E-mail info@ntis.gov

Web site http://www.ntis.gov/support/ordernowabout.htm

Reports are available to DOE employees, DOE contractors, Energy Technology Data Exchange (ETDE) representatives, and International Nuclear Information System (INIS) representatives from the following source.

Office of Scientific and Technical Information

P.O. Box 62

Oak Ridge, TN 37831

Telephone 865-576-8401

Fax 865-576-5728

E-mail reports@osti.gov

Web site http://www.osti.gov/contact.html

This report was prepared as an account of work sponsored by an agency of the United States Government. Neither the United States Government nor any agency thereof, nor any of their employees, makes any warranty, express or implied, or assumes any legal liability or responsibility for the accuracy, completeness, or usefulness of any information, apparatus, product, or process disclosed, or represents that its use would not infringe privately owned rights. Reference herein to any specific commercial product, process, or service by trade name, trademark, manufacturer, or otherwise, does not necessarily constitute or imply its endorsement, recommendation, or favoring by the United States Government or any agency thereof. The views and opinions of authors expressed herein do not necessarily state or reflect those of the United States Government or any agency thereof. 
ORNL/TM-2006/155

\title{
WILDLIFE MANAGEMENT PLAN FOR THE OAK RIDGE RESERVATION
}

\author{
Neil R. Giffen \\ Environmental Sciences Division, Oak Ridge National Laboratory \\ James W. Evans \\ Tennessee Wildlife Resources Agency \\ Patricia D. Parr \\ Facilities and Operations Directorate, Oak Ridge National Laboratory
}

August 2007

Prepared by

OAK RIDGE NATIONAL LABORATORY

P.O. Box 2008

Oak Ridge, Tennessee 37831-6283

managed by

UT-BATTELLE, LLC

for the

U.S. DEPARTMENT OF ENERGY

under contract DE-AC05-00OR2272 



\section{CONTENTS}

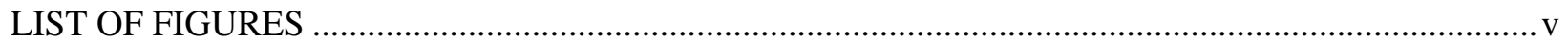

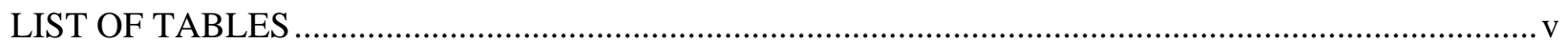

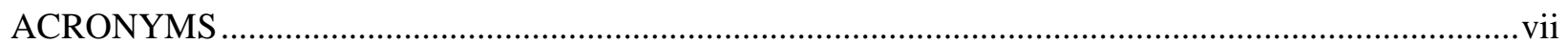

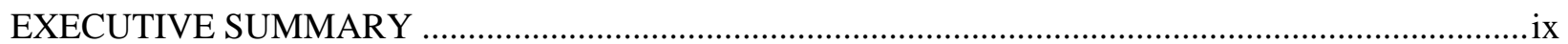

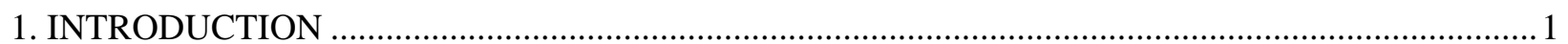

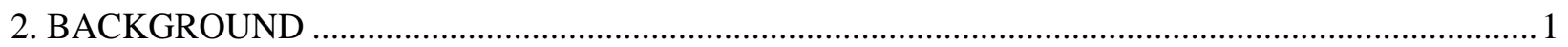

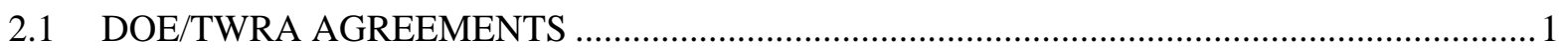

2.2 LEGISLATIVE AND REGULATORY REQUIREMENTS FOR WILDLIFE

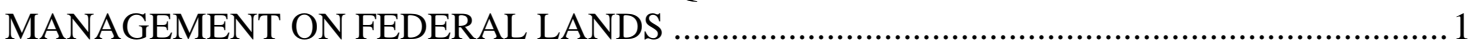

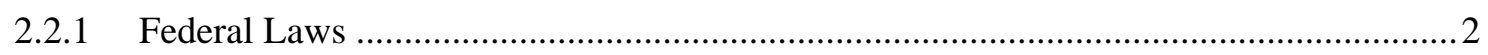

2.2.2 Executive Orders and Presidential Memoranda ......................................................5

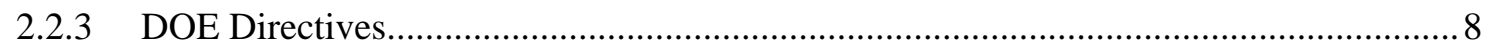

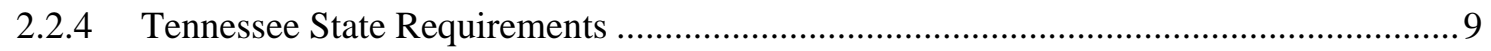

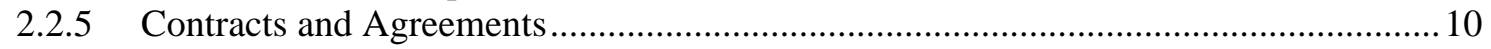

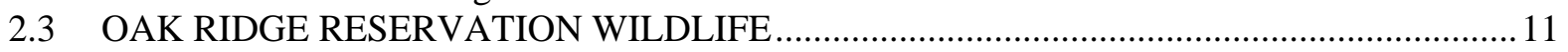

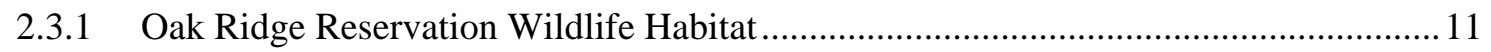

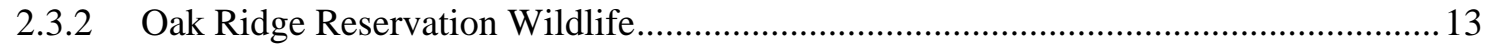

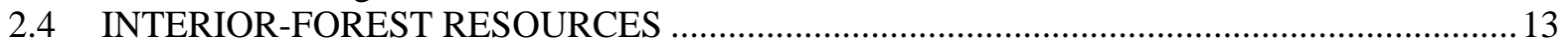

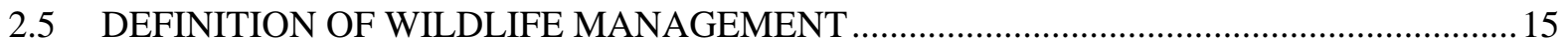

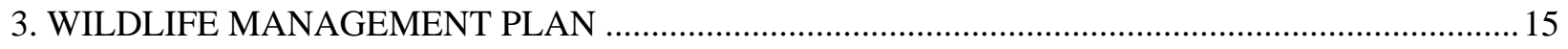

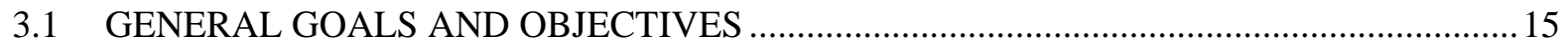

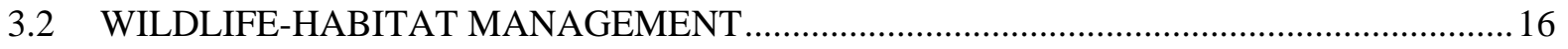

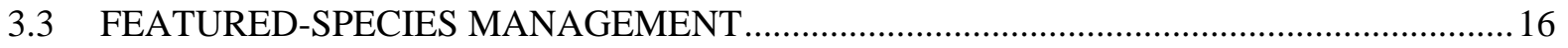

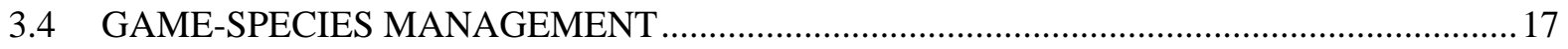

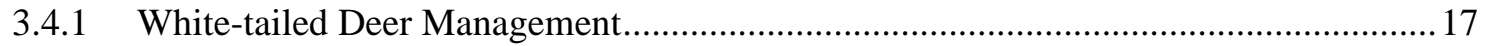

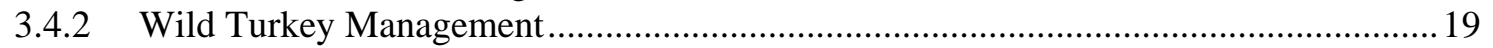

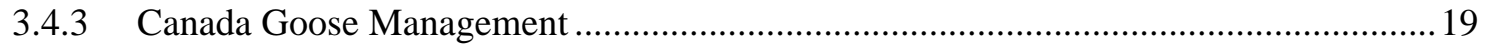

3.5 MANAGEMENT OF THE THREE BEND SCENIC AND WILDLIFE

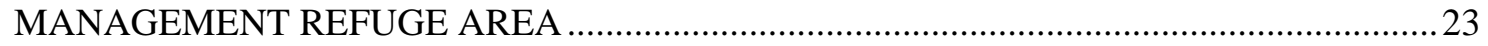

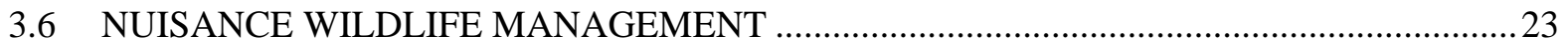

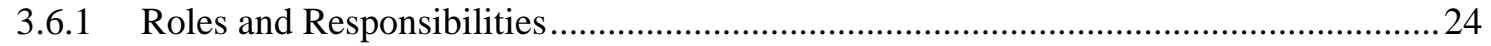

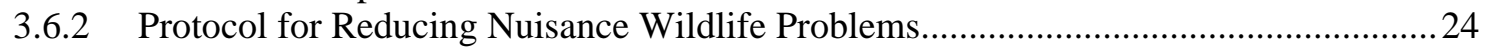

3.6.3 Nuisance Wildlife Management Issues around Facilities ............................................25

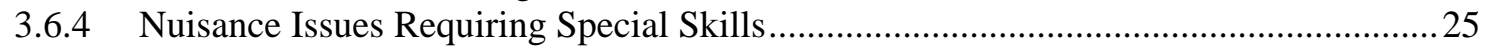

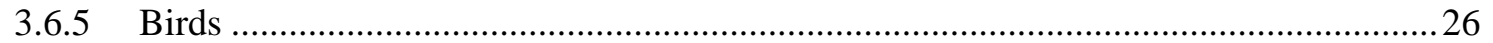

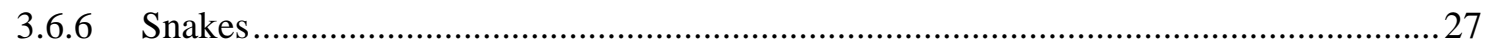

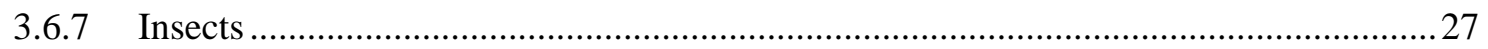

3.7 SENSITIVE SPECIES INVENTORY, PROTECTION, AND MANAGEMENT ...................27

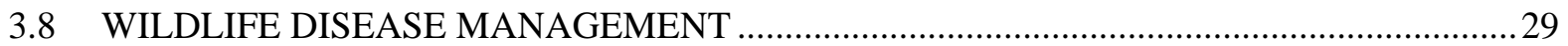

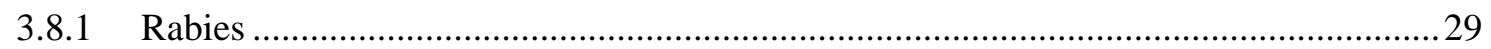

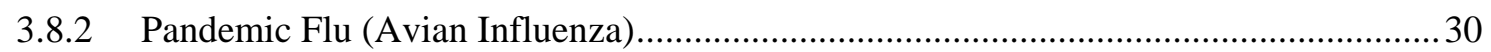

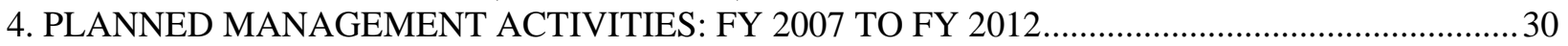

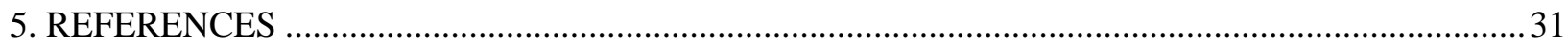

APPENDIX A MEMORANDUM OF UNDERSTANDING BETWEEN THE UNITED STATES FISH AND WILDLIFE SERVICE, DEPARTMENT OF THE INTERIOR, AND THE DEPARTMENT OF ENERGY REGARDING IMPLEMENTATION OF EXECUTIVE ORDER 13186, “RESPONSIBILITIES OF FEDERAL AGENCIES TO PROTECT MIGRATORY BIRDS” AND SELECTED PORTIONS OF EXECUTIVE ORDER 13186.. 
APPENDIX B SELECTED PORTIONS OF DOE ORDER 450.1, ENVIRONMENTAL

PROTECTION PROGRAM, CHANGE 2 (DECEMBER 7, 2005).

APPENDIX C OUTLINE OF SELECTED PARTS OF THE TENNESSEE LAWS

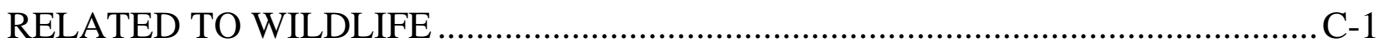

APPENDIX D WILDLIFE HABITATS ON THE OAK RIDGE RESERVATION .............................D-1

APPENDIX E VERTEBRATE WILDLIFE SPECIES OF THE OAK RIDGE

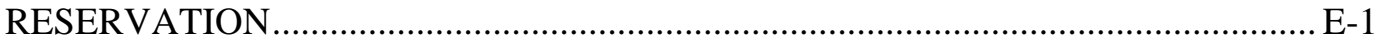

APPENDIX F DEFINITION OF WILDLIFE MANAGEMENT …................................................. F-1

APPENDIX G WILDLIFE MANAGEMENT ACTIVITIES FISCAL YEAR 1983

THROUGH FISCAL YEAR 2006 .......................................................................... 


\section{LIST OF FIGURES}

Figure

Page

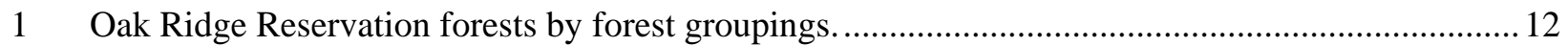

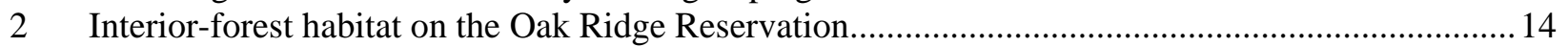

3 Deer/vehicle collisions on the Oak Ridge Reservation and vicinity. ............................................. 18

$4 \quad$ Historical white-tailed deer harvest numbers for the Oak Ridge Reservation. .................................. 20

$5 \quad$ Historical deer-hunting-acreage total for the Oak Ridge Reservation. .........................................2 21

$6 \quad$ Historical wild turkey harvest numbers for the Oak Ridge Reservation........................................... 22

\section{LIST OF TABLES}

Table

Page

1 Wildlife species of concern reported for the Oak Ridge Reservation 



\section{ACRONYMS}

$\begin{array}{ll}\text { AEC } & \text { Atomic Energy Commission } \\ \text { APHIS } & \text { Animal and Plant Health Inspection Service } \\ \text { CERCLA } & \text { Comprehensive Environmental Response, Compensation, and Liability Act } \\ \text { CFR } & \text { Code of Federal Regulations } \\ \text { CRD } & \text { Contractor Requirements Document } \\ \text { DOE } & \text { Department of Energy } \\ \text { EMS } & \text { environmental management system } \\ \text { ES\&H } & \text { environment, safety, and health } \\ \text { ESA } & \text { Endangered Species Act } \\ \text { FR } & \text { Federal Register } \\ \text { FWCA } & \text { Fish and Wildlife Coordination Act } \\ \text { FY } & \text { fiscal year } \\ \text { ISMS } & \text { Integrated Safety Management System } \\ \text { MBTA } & \text { Migratory Bird Treaty Act } \\ \text { MOU } & \text { Memorandum of Understanding } \\ \text { NEPA } & \text { National Environmental Policy Act } \\ \text { NMFS } & \text { National Marine Fisheries Service } \\ \text { ORNL } & \text { Oak Ridge National Laboratory } \\ \text { ORO } & \text { Oak Ridge Operations } \\ \text { ORR } & \text { Oak Ridge Reservation } \\ \text { PIF } & \text { Partners in Flight } \\ \text { QDM } & \text { quality deer management } \\ \text { ROD } & \text { Record of Decision } \\ \text { T\&E } & \text { threatened and endangered } \\ \text { TCA } & \text { Tennessee Code Annotated } \\ \text { TDEC } & \text { Tennessee Department of Environment and Conservation } \\ \text { TWRA } & \text { Tennessee Wildlife Resources Agency } \\ \text { USC } & \text { United States Code } \\ \text { USDA } & \text { United States Department of Agriculture } \\ \text { USFWS } & \text { U.S. Fish and Wildlife Service } \\ \text { UT } & \text { University of Tennessee } \\ \text { WMA } & \text { Wildlife Management Area } \\ & \end{array}$





\section{EXECUTIVE SUMMARY}

This document outlines a plan for management of the wildlife resources on the Department of Energy's (DOE's) Oak Ridge Reservation. Management includes wildlife population control through hunting, trapping, removal, and habitat manipulation; wildlife damage control; restoration of wildlife species; preservation, management, and enhancement of wildlife habitats; coordination of wildlife studies and characterization of areas; and law enforcement. Wildlife resources are divided into several categories, each with a specific set of objectives and procedures for attaining them. These objectives are management of (1) wildlife habitats to ensure that all resident wildlife species exist on the Reservation in viable numbers; (2) featured species to produce selected species in desired numbers on designated land units; (3) game species for research, education, recreation, and public safety; (4) the Three Bend Scenic and Wildlife Management Refuge Area; (5) nuisance wildlife, including nonnative species, to achieve adequate population control for the maintenance of health and safety on the Reservation; (6) sensitive species (i.e., state or federally listed as endangered, threatened, of special concern, or in need of management) through preservation and protection of both the species and habitats critical to the survival of those species; and (7) wildlife disease. Achievement of the objectives is a joint effort between the Tennessee Wildlife Resources Agency (TWRA) and the Oak Ridge National Laboratory through agreements between TWRA and DOE and between DOE and UT-Battelle, LLC. 



\section{INTRODUCTION}

The 33,114-acre (13,400-ha) Oak Ridge Reservation (ORR) was designated a Wildlife Management Area (WMA) on November 30, 1984, through a cooperative agreement between the Tennessee Wildlife Resources Agency (TWRA) and the Oak Ridge Operations (ORO) of the Department of Energy (DOE).

This management plan will (1) describe wildlife management on the ORR/WMA and (2) establish long-term wildlife goals, with specific objectives for the period fiscal year (FY) 2007 through FY 2011. This document updates and replaces Volume 27 of the Resource Management Plan for the ORR (Parr and Evans 1992).

Management of wildlife on an area as large as the ORR is necessary to ensure public safety (e.g., reduce deer/vehicle collisions, reduce Canada goose/human interactions) and maximize wildlife health and diversity. Maintaining important habitats is essential to the preservation of species in need of management. Characterizing habitats and understanding wildlife requirements is necessary for making decisions that could affect species or habitats and for evaluating potential impacts of proposed activities. Information on the species and habitat types present, wildlife diversity, and protected habitat locations is also essential in land-use planning and decision making. Additionally, information collected through the wildlife program will be used in regional forest and wildlife management throughout the state.

This document provides the framework for compliance with state and federal laws currently in place for the protection and management of wildlife populations on federal lands. In following the guidelines of a formal wildlife management plan document, DOE shows that it recognizes the importance of protecting, managing, and enhancing wildlife populations. Furthermore, the establishment of a formal plan provides the basis for DOE to comply with guidelines and regulations pertaining to wildlife populations. Active management and regular surveys of wildlife populations on the ORR attest to DOE's commitment to the protection of these populations, as is required under the applicable statutes.

\section{BACKGROUND}

\subsection{DOE/TWRA AGREEMENTS}

The cooperative agreement of November 30, 1984, between DOE and TWRA was renewed for an additional 5 years on December 1, 1989. The agreement was renewed as a license agreement for an additional 2 years on December 1, 1994; for 5 years in November, 1996; for 5 years in November 2001; and for another 5 years in November 2006.

TWRA has the responsibility to provide wildlife officers for enforcing Tennessee game and fish laws, rules, and regulations. TWRA also agrees, consistent with the government's programmatic use of lands, to develop the area for wildlife species by the application of scientific management techniques that are compatible with good land use and to carry out other wildlife-oriented projects as specified by DOE. The ORR Wildlife Management Coordinator coordinates with TWRA on planned activities and facilitates a variety of wildlife management programs in coordination with the DOE Reservation Management Coordinator, the DOE Wildlife Management Technical Contact, and the ORNL Natural Resources Manager.

\subsection{LEGISLATIVE AND REGULATORY REQUIREMENTS FOR WILDLIFE MANAGEMENT ON FEDERAL LANDS}

DOE is committed to wildlife management and conservation and works not only with TWRA, but also with the U.S. Fish and Wildlife Service (USFWS) and other agencies to be a good steward of its land and the natural resources on it.

A number of regulatory requirements direct DOE's wildlife management on the ORR, including

- $\quad$ federal laws, executive orders, and presidential memoranda;

- $\quad$ DOE directives (e.g., orders, guidance); 
- $\quad$ Tennessee state laws and regulations; and

- $\quad$ contracts and agreements for managing DOE sites.

Some of these items directly require protection and management of wildlife, while others indirectly protect them through requirements to protect the ecosystems or habitats they use or to manage invasive species that might compete with them.

\subsubsection{Federal Laws}

A number of federal laws require or encourage federal agencies to actively manage natural resources, including wildlife, on their lands. Regulations that have the force of law implement many of these federal laws, and DOE must also comply with them. (Summaries of some of these laws and their implementing regulations are available on the DOE Headquarters Web site at: http://www.eh.doe.gov/oepa/laws/.)

The following laws are listed in chronological order of their initial passage by Congress. Each law has been amended at least once; the discussions below reflect the most recent versions of each law, including all amendments.

\section{Migratory Bird Treaty Act}

The Migratory Bird Treaty Act (MBTA) (Title 16, United States Code [USC], Sects. 703-712) of 1918 implements treaties - signed by the United States and Canada, Japan, Mexico, and the former Soviet Union-for the protection of shared migratory bird resources. The act protects migratory birds by governing the taking, killing, possession, transportation, and importation of such birds; their eggs, parts, and nests; and any product, manufactured or not, from such items.

The USFWS has developed a list of migratory birds that are protected under the act. The list can be found at Title 50, Code of Federal Regulations (CFR), Part 10.13 or at the following Web page: http://www.USFWS.gov/migratorybirds/intrnltr/mbta/mbtandx.html. (The latter list provides updated scientific and common names that conform to the most recent taxonomy with cross references to the names in the CFR list.)

The USFWS has also published a list of 125 bird species (Title 70, Federal Register [FR], Part 12710; March 15, 2005, available at http://migratorybirds.USFWS.gov) that are not native to the United States and, therefore, are not protected under the MBTA.

\section{Fish and Wildlife Coordination Act}

The Fish and Wildlife Coordination Act (FWCA) (16 USC 661-667e) of 1934 recognizes the vital contribution of wildlife resources, both animals and plants, to the nation. The act requires federal agencies to consult with the USFWS and appropriate state wildlife agencies when they plan to conduct any activity involving the impoundment, diversion, deepening, control, or modification of a body of water. It requires equal consideration and coordination be given to conservation of fish and wildlife as to other waterresource values during project planning involving water bodies larger than 10 acres (4 ha). Federal agencies must assess the impacts of their planned activity on wildlife resources and modify project plans by justifiable means and measures to prevent loss or damage to those resources. Reports and recommendations prepared by these agencies are to document project effects on wildlife and identify measures that can be adopted to prevent loss or damage to wildlife resources.

The FWCA authorizes the Secretaries of Agriculture and Commerce to provide assistance to and cooperate with federal and state agencies to protect, rear, stock, and increase the supply of game and furbearing animals. The FWCA also directs the Secretaries to study the effects of polluting substances (e.g., domestic sewage; mine, petroleum, and industrial wastes; silt from erosion) on wildlife. In addition, this act authorizes the preparation of plans to protect wildlife resources, completion of wildlife surveys on any public lands, and use of surplus federal property for wildlife conservation purposes. 


\section{Bald Eagle Protection Act}

The Bald Eagle Protection Act (16 USC 668-668d) of 1940 protects bald and golden eagles by prohibiting, except under certain specified conditions, the taking or possession of and commerce in such birds. (Although the short title of the act mentions only bald eagles, its provisions also apply to golden eagles.) The act imposes criminal and civil penalties on anyone who, unless exempted, takes; possesses; sells; purchases; barters; offers to sell, purchase, or barter; transports; exports; or imports at any time or in any manner a bald or golden eagle, alive or dead, or any part, nest, or egg of those eagles. "Take" means to pursue, shoot, shoot at, poison, wound, kill, capture, trap, collect, molest, or disturb. "Transport” means to convey or carry by any means or to deliver or receive for conveyance.

\section{Sikes Act}

The Sikes Act (16 USC 670a-670o) of 1960 calls for cooperation with state fish and game agencies in planning and managing wildlife habitat on federal lands. This act is particularly relevant to wildlife management on the ORR, as it specifically mentions what are now lands controlled by DOE. It states that the "Secretary of the Interior shall develop, with the prior written approval of the Atomic Energy Commission (AEC) [now a part of DOE], a comprehensive plan for conservation and rehabilitation programs to be implemented on public land under the jurisdiction of the Chairman" of the AEC (now the Secretary of DOE). "Each such plan shall be developed after the Secretary of the Interior makes, with the prior written approval of the Chairman ... and in consultation with the state agencies, necessary studies and surveys of the land concerned to determine where conservation and rehabilitation programs are most needed.” The act further states that "each comprehensive plan developed . . . shall be consistent with any overall land-use and management plans for the lands involved." Programs shall include, but not be limited to, specific habitat-improvement projects and related activities that provide adequate protection for species of fish, wildlife, and plants considered threatened or endangered.

The phrase "public land" includes all lands under the jurisdiction of DOE. The phrase "conservation and rehabilitation programs" means to ". . . utilize those methods and procedures which are necessary to protect, conserve, and enhance wildlife, fish, and game resources to the maximum extent practicable ... consistent with any overall land-use and management plans for the lands involved.”

\section{National Environmental Policy Act}

The National Environmental Policy Act (NEPA) (42 USC 4321-4347) of 1969 declares that it is a national policy to encourage productive and enjoyable harmony between people and the environment and to promote efforts to better understand and prevent damage to ecological systems and natural resources that are important to the nation. In the act, Congress stated that it is the continuing responsibility of the federal government to use all practicable means to create and maintain conditions under which people and nature can exist in productive harmony and to fulfill the social, economic, and other requirements of present and future generations.

NEPA requires all federal agencies to consider the effects of their actions on the environment; employ an interdisciplinary approach in decision making; and develop means to ensure that unquantified environmental values are given appropriate consideration, along with economic and technical aspects of the actions. Thus, when DOE proposes an action, it must develop a NEPA document (e.g., categorical exclusion, environmental assessment, environmental impact statement) to consider the potential impacts. Compliance with several other wildlife conservation acts (e.g., Endangered Species Act [ESA], FWCA) is often integrated with NEPA implementation.

\section{Endangered Species Act}

The purpose of the ESA (16 USC 1531-1544) of 1973 is to preserve plants and animals facing extinction. It mandates the conservation of proposed and listed threatened and endangered (T\&E) species 
and the designated critical habitats supporting them. The act prohibits the harm, harassment, trade, or capture of endangered species and provides for the protection of threatened species. The USFWS ${ }^{1}$ maintains lists of designated T\&E species in 50 CFR 17 and updates them as needed.

Section 7 requires all federal agencies, including DOE, to ensure that any action they authorize, fund, or carry out does not jeopardize the continued existence of T\&E species or result in the destruction or adverse modification of designated critical habitats that are important in conserving those species. The USFWS and National Marine Fisheries Service (NMFS) have established informal and formal consultation procedures in 50 CFR 402, “Consultation by Federal Agencies,” that implement this section of the act.

If DOE proposes an action on the ORR and if no previous NEPA documentation exists for the area involved in any alternative under consideration, a biological survey and evaluation might be required to determine if any T\&E species are or could be present. Initial consultation with the USFWS can take from 30 to $45 \mathrm{~d}$. However, field surveys, if required, could extend in excess of 1 year to identify seasonal issues. If a listed T\&E species might be affected by the action, a detailed biological assessment of potential impacts can be prepared independently or concurrently with the NEPA document and included as an appendix to that document. A biological opinion issued by USFWS at the conclusion of consultation can include a statement authorizing taking of a T\&E species that might occur incidental to an otherwise legal activity.

Section 7(a) of the act requires federal agencies to use their authorities to further the purposes of the act by carrying out programs to conserve listed T\&E species. Section 9 lists actions that are prohibited under the act, including damaging or destroying endangered plants on federal lands or taking a listed species unless such taking is incidental to an otherwise legal activity and has been specifically allowed.

\section{Federal Noxious Weed Act}

The Federal Noxious Weed Act (7 USC 2814²) of 1974 requires each federal land-managing agency to establish integrated management systems to control or contain undesirable plant species targeted under cooperative agreements with state agencies. Such systems are to be developed using an interdisciplinary approach that can include general land management practices such as manipulating wildlife grazing strategies or improving wildlife habitat. The interdisciplinary approach should include participation by personnel with experience in wildlife biology and should consider the ecological consequences of implementing the program. The Invasive Plant Management Plan for the Oak Ridge Reservation (Parr et al. 2004) implements this protection for wildlife on the ORR.

\section{Fish and Wildlife Conservation Act}

The Fish and Wildlife Conservation Act (16 USC 2901-2912) of 1980 is commonly known as the "Nongame Act." The purpose of the act is to provide financial and technical assistance to states for the development, revision, and implementation of conservation plans and programs for nongame fish and wildlife. It encourages federal agencies, such as DOE, to use their statutory and administrative authority to protect and promote the conservation of nongame fish and wildlife and their habitats.

\section{Comprehensive Environmental Response, Compensation, and Liability Act}

The purpose of the Comprehensive Environmental Response, Compensation, and Liability Act (CERCLA) of 1980 (also referred to as “Superfund") (42 USC 9601 et seq.) is to clean up sites contaminated by hazardous-substance releases and to ensure that the public is compensated for natural-

\footnotetext{
${ }^{1}$ The USFWS shares responsibility for administering the ESA with the NMFS in the Department of Commerce. NMFS is responsible for only marine species; therefore, that agency would not be involved in any T\&E species consultations on the ORR.

${ }^{2}$ Sections 2801-2813 were repealed by Pub. L. 106-224, June 20, 2000.
} 
resource injuries caused by such releases. The act designates the President of the United States as the trustee on behalf of the public for federally protected or managed natural resources. This responsibility has been delegated to federal agencies, including DOE. (See discussion of Executive Order 12580 below.) The act defines natural resources as "land, fish, wildlife, biota, air, water, groundwater, drinking supplies, and other such resources.”

As a natural-resource trustee for land that it manages, DOE has a broad responsibility for such natural resources under its jurisdiction. ${ }^{3}$ After notification or discovery of a natural-resource injury, loss, or threat, DOE will take appropriate actions. These actions can include conducting a preliminary survey of areas affected by a discharge or release to determine if natural resources are or might be impacted; cooperating with the on-scene coordinator/regional project manager in coordinating assessments, investigations, and planning; and carrying out a plan for restoration, rehabilitation, replacement, or acquisition of equivalent natural resources.

DOE, as a natural-resource trustee, can assess damages “. . . for injury to, destruction of, or loss of natural resources ...” following a release of hazardous substances. Assessments are made on the basis of "residual” injury that was not or could not be addressed by the selected remedy.

\section{North American Wetlands Conservation Act}

Section 4408 of the North American Wetlands Conservation Act (16 USC 4401-4414) of 1989 requires the head of each federal agency responsible for federal lands and waters to cooperate with the Director of the USFWS to restore, protect, and enhance the wetland ecosystems and other habitats for migratory birds, fish, and wildlife within the lands and waters of the agency.

\section{Other Laws}

DOE and its operating contractors are also subject to laws and regulations pertaining to radiation (e.g., Atomic Energy Act) and contaminants regulated under other laws (e.g., Resource Conservation and Recovery Act, Toxic Substances Control Act) that are present on its lands as a result of past and continuing activities. Although this plan is not intended to deal with such issues, where relevant, reference will be made to such contaminants in wildlife and their impacts.

\subsubsection{Executive Orders and Presidential Memoranda}

Executive orders and presidential memoranda also provide direction to DOE in managing its lands. The following summaries cover those that pertain, directly or indirectly, to wildlife management.

\section{Executive Order 11990: Protection of Wetlands}

Executive Order 11990, signed May 24, 1977, (published May 25, 1977, at 42 FR 269614) establishes wetland protection as the official policy of all federal agencies. The order directs each agency to provide leadership and "to minimize the destruction, loss or degradation of wetlands, and to preserve and enhance the natural and beneficial values of wetlands.” The executive order applies to federally undertaken, financed, or assisted construction and improvements in or with significant impacts on wetlands.

\footnotetext{
${ }^{3}$ A guidance document has been prepared to assist DOE Program and Field Organizations in understanding and meeting their natural-resource-trustee responsibilities, Integrating Natural Resource Damage Assessment and Environmental Restoration Activities at DOE Facilities (DOE 1993). Other guidance on natural resources damage assessment can be found under the "Policy and Guidance" button on the DOE Environmental Policy and Guidance Web site (http://homer.ornl.gov/oepa/).

${ }^{4}$ Executive order 12608 (September 9, 1987), Elimination of Unnecessary Executive Orders and Technical Amendments to Others, amended Section 6 of this executive order.
} 
Agencies are to avoid adverse impacts on wetlands wherever there is a practicable alternative. Work conducted or funded by a federal agency should not call for new construction in wetlands unless the head of the agency finds that there is no practicable alternative to such construction and the proposed action includes all practicable measures to minimize damage to wetlands. In making this finding, the head of the agency can take into account economic, environmental, and other pertinent factors. Agencies are also required to provide for early public review of any plans or proposals for new construction in wetlands.

Under this executive order, DOE must preserve and enhance the natural and beneficial values of wetlands when (1) acquiring, managing, and disposing of its lands and facilities; (2) undertaking, financing, or assisting construction and improvements; and (3) conducting any activities and programs affecting land use, including, but not limited to, water and related land-resources planning, regulating, and licensing activities.

In carrying out the activities described above, DOE must consider a proposal's effect on the survival and quality of the wetlands. Among the values of wetlands to be considered are maintenance of natural systems, including conservation and long-term productivity of existing flora and fauna; species and habitat diversity and stability; hydrologic utility; fish, wildlife, timber, food, and fiber resources; and scientific uses.

DOE's regulations implementing this executive order are found in 10 CFR 1022, "Compliance with Floodplain and Wetland Environmental Review Requirements.” They can be accessed on line at http://www.eh.doe.gov/nepa/tools/guidance/volume2/1-3-10CFR1022-68fr51429.pdf.

\section{Executive Order 12580: Superfund Implementation}

This executive order, signed January 23, 1987, (published January 29, 1987, at 52 FR 29235) addresses various federal agency activities in implementing the statutory provisions and regulations of CERCLA, as described above. It delegates various presidential responsibilities imposed under CERCLA to officials in federal department agencies, including naming DOE as a federal trustee. Accordingly, DOE acts as a natural-resource trustee for those resources it manages.

\section{Executive Order 13112: Invasive Species}

This executive order, signed February 3, 1999, (published February 8, 1999, at 64 FR 6183) directs all federal agencies to address invasive-species concerns and refrain from actions likely to increase invasive-species problems. The purpose of this executive order is to prevent the introduction of invasive species; to provide for their control; and to minimize the economic, ecological, and human health impacts that such species cause.

The Invasive Plant Management Plan for the Oak Ridge Reservation (Parr et al. 2004) implements this executive order and interacts with this wildlife management plan to protect ORR wildlife from the impacts of invasive species.

\section{Executive Order 13186: Responsibilities of Federal Agencies to Protect Migratory Birds}

This executive order, signed January 10, 2001, (published January 17, 2001, at 66 FR 3853) requires federal agencies — within existing budgets, missions, and responsibilities - to avoid or minimize the negative impact of their actions on migratory birds. (See MBTA summary in Sect. 2.2.1 above.) Agencies must actively protect birds and their surroundings by, for example, restoring and enhancing habitat,

${ }^{5}$ Executive order 12777 (October 18, 1991), Implementation of Section 311 of the Federal Water Pollution Control Act of October 18, 1972, as Amended, and the Oil Pollution Act of 1990, replaced section 1 of this executive order Executive order 13016 (August 28, 1996), Amendment to Executive Order No. 12580, added new subsections (c)(3) and (d)(3) to section 4. Executive order 13286 (February 28, 2003), Amendment of Executive Orders, and Other Actions, in Connection with the Transfer of Certain Functions to the Secretary of Homeland Security, amended this executive order by removing reference to the Federal Emergency Management Agency and inserting the Department of Homeland Security. 
preventing or abating pollution affecting birds, and incorporating migratory-bird conservation into agency planning processes.

The executive order requires each agency to develop a Memorandum of Understanding (MOU) with the USFWS to promote the conservation of migratory bird populations. DOE's MOU with the USFWS was approved on August 3, 2006, and was published on November 13, 2006 (71 FR 66170). It is effective until August 3, 2011.

The MOU commits DOE to cooperate with the USFWS to "substantially contribute to the conservation and management of migratory birds and their habitats.” It affirms DOE's commitment to "[take] its environmental stewardship role seriously and [advocate] a proactive management stance toward the natural environment.” The MOU details the individual and collective obligations of DOE and the USFWS, some of which are listed below.

- $\quad$ Both DOE and the USFWS shall

- protect, restore, enhance, and manage habitats of migratory birds and

- promote collaborative inventorying, monitoring, management studies, research, and information exchange related to the conservation of migratory birds and management of their habitats.

- $\quad$ DOE shall

— integrate migratory-bird-conservation principles, measures, and practices into agency activities;

- protect, restore, enhance, and manage habitats of migratory birds;

- incorporate migratory-bird-habitat and population-management objectives and recommendations into planning processes, including DOE site planning documents; and

- recognize and promote the ecological, economic, and recreational values of migratory birds into outreach and educational materials and activities.

See Appendix A for the complete DOE/USFWS MOU and selected portions of this executive order that detail DOE’s responsibilities.

\section{Executive Order 13148: Greening the Government through Leadership in Environmental Management}

Executive Order 13148, signed on April 21, 2000, (published April 26, 2000, at 65 FR 24595) requires federal agencies to incorporate environmental management systems (EMSs) into the agency's day-to-day decision-making and long-term-planning processes.

This executive order revoked the presidential memorandum for the heads of executive departments and agencies on environmentally and economically beneficial practices on federal landscaped grounds dated August 22, 1994. That memorandum required federal agencies' landscaping programs to consider use of environmentally sensitive landscaping practices and native plants. It promoted the sustainable management of federal facility lands through implementation of cost-effective, environmentally sound landscaping practices and programs to reduce adverse impacts to the natural environment. Although this presidential memorandum has been revoked, this executive order requires agencies to incorporate the guidance generated by it into their landscaping practices and calls for the guidance to be updated, if necessary. Use of native plants is important in providing suitable habitat for native wildlife. 


\subsubsection{DOE Directives}

DOE directives include orders, policies, guidance, and regulations that provide for management of DOE lands. The ones most applicable to wildlife protection and management are described below. DOE directives are available on-line at: http://www.directives.doe.gov/directives/current.html.

\section{DOE O 450.1, Change 2: Environmental Management Program (December 7, 2005)}

This order is DOE's major environmental directive and establishes a general framework for DOE's environmental protection programs. It promotes implementation of sound stewardship practices that are protective of the air, water, land, and ecological resources impacted by DOE operations, allowing DOE to meet or exceed compliance with applicable environmental and resource-protection laws, regulations, and DOE requirements in a cost-effective way. Appendix B provides excerpts of this order that are specific to wildlife management on the ORR.

This DOE order applies to all DOE elements that are responsible for managing and operating DOE facilities. It requires them to ensure that the site Integrated Safety Management System (ISMS) includes an EMS. (This integration of an EMS into ISMS is referred to as ISMS/EMS). An EMS is a continuing cycle of planning, implementing, evaluating, and improving processes and actions undertaken to achieve environmental goals. To implement this order, DOE elements must prepare EMSs that protect natural resources, including biota; protect site resources from wildland and operational fires (see the specific guidance on wildland fires in the last paragraph of this section); and promote the long-term stewardship of a site's natural resources.

DOE operations, field, and site office managers are responsible for integrating, where appropriate, beneficial landscape practices at their facilities into all new landscaping programs. They must also ensure that the site's annual budgetary processes include the funding and resources needed to implement this order. They must conduct environmental monitoring to, among other things, evaluate the potential impacts to the biota in the vicinity of a release from a DOE activity. The analytical work supporting environmental monitoring must be implemented using a consistent system for collecting, assessing, and documenting environmental data of known and documented quality.

The order includes additional requirements that contractors must follow to comply with it. Section 2.2.5 below includes further discussion of these requirements.

DOE has developed a series of guides that describes suggested nonmandatory approaches for meeting the requirements of this order. DOE G 450-1.4, Wildland Fire Management Program, (published February 11, 2004) suggests ways that DOE sites can implement the requirement of the order to protect resources from wildland and operational fires, including prescribed burns instituted to improve wildlife habitat, restore natural ecological processes, and achieve the management objectives adopted in the approved land-use planning and management process for the site.

\section{DOE P 450.7: Environment, Safety and Health (ES\&H) Goals (August 2, 2004)}

The purpose of this policy is to establish ES\&H goals for DOE personnel and its contractors. It states DOE's policy that it expects its employees and contractors to "respect . . . the environment."

\section{DOE P 454.1: Use of Institutional Controls (April 9, 2003)}

This policy delineates how DOE will use institutional controls to manage resources, facilities, and properties under its control and implement its programmatic responsibilities. The policy guides sitespecific and programmatic decisions on DOE's planning, maintenance, and implementation of institutional controls; addresses responsibilities related to DOE's role as a steward of federal lands and properties; and identifies activities that DOE needs to accomplish. The policy helps ensure that institutional controls to protect the public and the environment will be established in accordance with the 
requirements of DOE O 450.1, described above, by integrating them into the EMS implementation framework.

DOE uses a wide range of institutional controls as part of its efforts to, among other things, protect and manage the environment, including natural resources. DOE's line management (e.g., operations office managers, field office managers) has primary responsibility for implementing this policy for properties under its control.

\section{DOE G 454.1-1: Implementation Guide for Use with DOE P 454.1, Use of Institutional Controls (October 14, 2005)}

This guide suggests nonmandatory approaches for meeting the requirements of DOE P 454.1. It provides information to assist DOE program and field offices in understanding what is necessary and acceptable for implementing the provisions of the policy. It also identifies issues that need to be addressed when considering the use of institutional controls to support DOE's diverse missions. Appendix A of the guide lists statutory, regulatory, and other directives that are drivers for uses of institutional controls at DOE sites, some of which are specific to protection and management of wildlife.

\subsubsection{Tennessee State Requirements}

Laws, rules, and regulations of the state of Tennessee are also applicable to DOE's management of wildlife on the ORR. Tennessee laws relating to wildlife resources are found in Title 70 of the Tennessee Code Annotated (TCA), an outline of the most applicable parts of which is provided in Appendix C of this report.

The primary state agencies dealing with wildlife protection are the Tennessee Department of Environment and Conservation (TDEC) (http://www.state.tn.us/environment/) and TWRA (http://www. state.tn.us/twra/).

TDEC was created to protect and improve the quality of the state's land, air, water, and recreation resources. The department administers a variety of programs to safeguard human health and the environment, including protecting endangered species of plants.

Rules and regulations that apply to TDEC are available at http://www.tennessee.gov/sos/rules/ 0400/0400.htm.

TWRA is responsible for the management of wildlife, including game animals, nongame species, fish, and T\&E species. The director of TWRA may enter into agreements with federal agencies for administration and management of an area, such as the ORR, established or used for wildlife management. TWRA also studies nongame wildlife to develop population, distribution, habitat, needs, limiting factors, and biological and ecological data. This information is used to determine management measures needed to sustain nongame wildlife and to develop programs designed to ensure the continued ability of nongame endangered or threatened wildlife to perpetuate themselves.

TWRA includes both hunting (http://www.state.tn.us/twra/huntmain.html) and nongame programs (http://www.state.tn.us/twra/nongmain.html). TWRA manages the ORR hunts for species such as deer, turkey, Canada goose, and ducks.

Rules and regulations that apply to TWRA can be found at http://www.state.tn.us/sos/rules/1660/ 1660.htm.

\section{Endangered or Threatened Species Lists}

The Tennessee Nongame and Endangered or Threatened Wildlife Species Conservation Act of 1974 (TCA 70-8-105) requires the Tennessee Wildlife Resources Commission to propose a list of those native species or subspecies of wildlife that are determined to be endangered and threatened within the state. The Rare Plant Protection and Conservation Act of 1985 (TCA 70-8-301) directs TDEC to develop a state list of endangered, threatened, and special-concern plants; conduct investigations on their status and conservation needs; and conduct education programs concerning rare plant conservation. 
A list of Tennessee T\&E species, both animal and plant, by county is available at http://tennessee. gov/environment/na/pdf/county.pdf.

\section{Habitat Protection}

Tennessee law protects aquatic habitats from pollution (TCA 70-4-206). Specifically, it states that "no pollution, including, but not limited to, dye waste, petroleum products, brine waste, or refuse from a mine, sawmill or construction activity, or industrial or domestic sewage, or any deleterious or poisonous substance or activity shall be thrown or allowed to run into, wash into or take place in public or private waters in quantities injurious to fish life or other aquatic organisms, or which could be injurious to the propagation of fish, or which results in the destruction of habitat for fish and aquatic life."

\subsubsection{Contracts and Agreements}

\section{Management Contract}

The contractor shall support DOE/ORO in its responsibilities for land-use planning and landmanagement activities as well as natural-resource management for the DOE ORR, which consists of 33,114 acres (13,400 ha) of federally owned land. The contractor's responsibilities are land and facility planning for the Oak Ridge National Laboratory (ORNL) site, coordinating and conducting research, and conducting operational and maintenance activities within the National Environmental Research Park. Information on contaminant- and environmental-monitoring activities on the ORR is available in the Annual Site Environmental Report (DOE 2006). These reports are available on-line at http://www.ornl.gov/aser.

Attachment 2 to DOE O 450.1 (discussed above), “Contractor Requirements Document” (CRD), delineates the responsibilities that contractors must meet to comply with that order. The CRD requires contractors to use an EMS incorporated into an ISMS to integrate the numerous environmental requirements placed on them by existing statutes, regulations, and policies. Contractors must provide for the systematic planning, integrated execution, and evaluation of programs for compliance with all applicable environmental-protection requirements. They must include policies, procedures, and training to identify activities with significant environmental impacts; manage, control, and mitigate the impacts of those activities; and assess performance and implement corrective actions where needed. They must promote the long-term stewardship of the ORR's natural resources. They must also ensure the early identification of, and appropriate response to, potential adverse environmental impacts associated with DOE operations, including, as appropriate, preoperational characterization and assessment and effluent and surveillance monitoring. They must assist DOE in meeting the requirements of Executive Order 13148 (see above). This assistance includes incorporating, where appropriate, environmentally and economically beneficial landscape practices into all new landscaping programs, policies, and practices for the ORR.

As part of integrating EMSs into their ISMSs, contractors must include protection of natural resources, including biota, and protection of site resources from wildland and operational fires. Some requirements from the CRD are listed in Appendix B.

\section{DOE Agreements with TDEC and TWRA}

DOE has entered into several agreements with state agencies. TWRA is responsible for general wildlife management on the ORR through an agreement with DOE/ORO. TWRA also actively manages the Three Bend Scenic and Wildlife Management Refuge Area (Three Bend Area) through an additional agreement with DOE.

TWRA will also manage the Black Oak Ridge Conservation Easement Area in accordance with a management plan to be jointly developed by TWRA and TDEC with input from the public. The Black Oak Ridge Conservation Easement was designated April 2005 through an agreement between DOE and 
the state of Tennessee to be set aside under CERCLA for damage done to Watts Bar Lake by DOE actions. It protects approximately 2965.95 acres (1200 ha) in the northwest corner of the ORR. This area includes valuable forest-interior habitat for important wildlife species, especially neotropical migrant birds.

DOE and the state have entered into a voluntary agreement, the Tennessee Oversight Agreement (available at http://tennessee.gov/environment/doeo/pdf/toa.pdf). In a spirit of partnership and cooperation, DOE and the state have agreed to find ways to achieve clean air, water, and land on the ORR. The agreement is designed to assure the citizens of Tennessee that their health, safety, and environment are being protected through existing programs and substantial new commitments by DOE. Through a program of independent monitoring and review by TDEC's DOE Oversight Division, the state will advise and assist DOE to ensure that its activities on the ORR do not adversely impact the public health, safety, and the environment.

\subsection{OAK RIDGE RESERVATION WILDLIFE}

\subsubsection{Oak Ridge Reservation Wildlife Habitat}

The ORR is mostly contiguous native eastern deciduous forest. Prior to government acquisition as a security buffer for military activities, the approximately 1000 individual farmsteads on the area now included in the ORR consisted of forest, woodlots, open grazed woodlands, and fields. Results of remotesensing analyses show that in 1994 about $70 \%$ of the ORR was in forest cover and about $20 \%$ was transitional, consisting of old fields, agricultural areas, cutover forestlands, roadsides, and utility corridors (Washington-Allen et al. 1995). Forested areas (hardwood and pine, with many areas in blocks greater than 100 acres [40 ha]) are found throughout the Reservation (Parr and Hughes 2006). Cutover forestland includes about 1100 acres ( $445 \mathrm{ha}$ ) of pine plantations killed in 1994 by southern pine beetles. These areas are now regenerating or have been replanted. Additional areas affected by the 1999-2000 pine beetle outbreak are being cut to salvage timber. Less than $2 \%$ of the Reservation remains as open agricultural fields (Mann et al. 1996). The forests are mostly oak-hickory, pine-hardwood, or pine. Minor areas of other hardwood-forest cover types are found throughout the ORR, including northern hardwoods, a few small natural stands of hemlock or white pine, and floodplain forests. Figure 1 shows ORR forests by forest groupings based on forestry compartment maps from the 1980s.

Outstanding features of the ORR for wildlife include its large areas of unfragmented, mature eastern deciduous hardwood forest and its overall habitat diversity, particularly in comparison to surrounding land uses. Such areas are increasingly uncommon in the region and the nation. Overall, the ORR provides a diversity of wildlife habitats both imbedded within this forest matrix and as a result of other activities that have occurred since the area was created in the 1940s. Thus, in addition to a variety of forested habitats and pine plantations, the ORR contains seminatural, managed grasslands and forest edge, which together provide considerable habitat diversity capable of supporting a variety of wildlife species. The resulting features of the ORR that provide habitat for wildlife are discussed further in Appendix D. Such habitat features include, among others, the following:

- $\quad$ large areas of mature hardwood forest;

- $\quad$ significant blocks of interior forest;

- $\quad$ sizeable areas of grassland;

- $\quad$ old fields at different stages of succession;

- $\quad$ unique or important vegetation communities;

- $\quad$ seminatural corridors;

- $\quad$ planted hardwoods and pines;

- $\quad$ bottomlands and wetlands, including an increasing number of beaver ponds;

- $\quad$ caves; and

- $\quad$ developed and semideveloped areas and roads. 


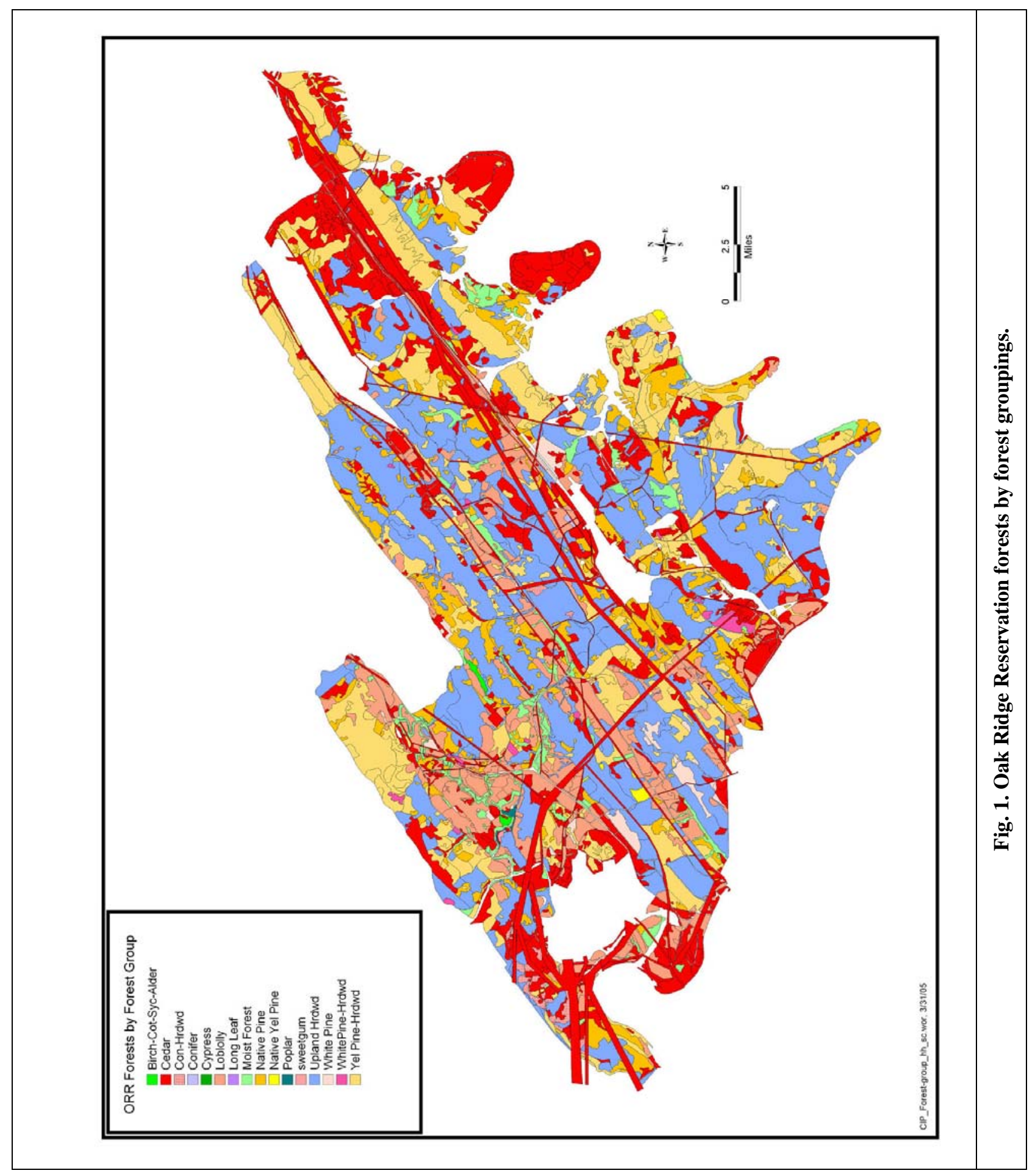




\subsubsection{Oak Ridge Reservation Wildlife}

The resulting diversity of wildlife species ranges from common species found in urban and suburban areas of eastern Tennessee to species with more restrictive requirements, such as interior-forest bird species. The ORR hosts about 63 species of fish; 59 species of reptiles and amphibians; up to 205 species of migratory, transient, and resident birds; and 38 species of mammals, as well as innumerable invertebrate species. Among these, 17 species of federal- or state-listed (endangered, threatened, or in need of management) vertebrate species have been confirmed in recent surveys (Mitchell et al. 1996). Furthermore, appropriate habitat for approximately 20 additional species has been identified. In addition, 13 of the recorded bird species are listed by Partners in Flight (PIF) as species of concern. PIF was launched in 1990 in response to growing concerns about declines in the populations of many land-bird species and to emphasize the conservation of birds not covered by existing conservation initiatives. The central premise of PIF has been that the resources of public and private organizations in North and South America must be combined, coordinated, and increased to achieve success in conserving bird populations in this hemisphere. PIF is a cooperative effort involving partnerships among federal, state, and local government agencies; foundations; professional organizations; conservation groups; industry, the academic community; and private individuals. Monitoring by PIF has also determined that 11 of the 16 species that are top conservation priorities in the region are present on the Reservation during the breeding season. Lists of vertebrate wildlife found on the ORR are presented in Appendix E.

Most of the ORR is relatively pristine when compared with the surrounding region, especially in the Valley and Ridge Physiographic Province (Mann et al. 1996). Viewed from the air, the ORR is clearly a large and nearly continuous island of forest within a landscape fragmented by urban development and agriculture. Many ecological communities (e.g., cedar barrens, river bluffs, and wetlands) with unique biota, often including rare species, are known to exist within the larger framework of mixed hardwood and pine forest on the ORR (Pounds, Parr, and Ryon 1993).

\subsection{INTERIOR-FOREST RESOURCES}

The ORR's extensive forest area, amounting to approximately 24,000 acres (9712 ha), is valuable not just for its size, but also because of its contiguous configuration (Fig. 2). Contiguous forest provides habitat for several plant and animal species not associated with smaller patches of forest close to edges. This is especially true for certain increasingly rare bird species. Deep-forest habitat is located away from large openings and typically has more than $70 \%$ canopy cover. A minimum of 50 contiguous acres (20 ha) of forest habitat can be used as a benchmark as the required acreage for the presence of many deep-forest wildlife species.

As human populations continue to increase and expand, large tracts of contiguous forest are becoming smaller and are broken into a greater number of pieces. Forest area is lost to clearing of land for industry, agriculture, and residential development and the remaining forest is further fragmented by associated roads and utility corridors. Fragmentation creates an "edge effect" that alters habitat conditions such as moisture regime, microclimate, and light penetration and can result in the introduction and spread of predators harmful to forest-dependent species. Nesting forest birds increasingly fall prey to predators associated with edge habitat such as feral cats, raccoons, and certain snake species. The creation of cleared areas throughout forests also opens the area to the brown-headed cowbird, a common nest parasite that uses edge habitat and parasitizes nests of forest birds. Cowbirds fly in from the edges to lay their eggs in the nests of forest birds, where the larger, more aggressive cowbird young outcompete the fledglings of the forest-bird species. As more edges are created through the forest, cowbird penetration and associated nest predation on forest species such as wood thrush increase. 


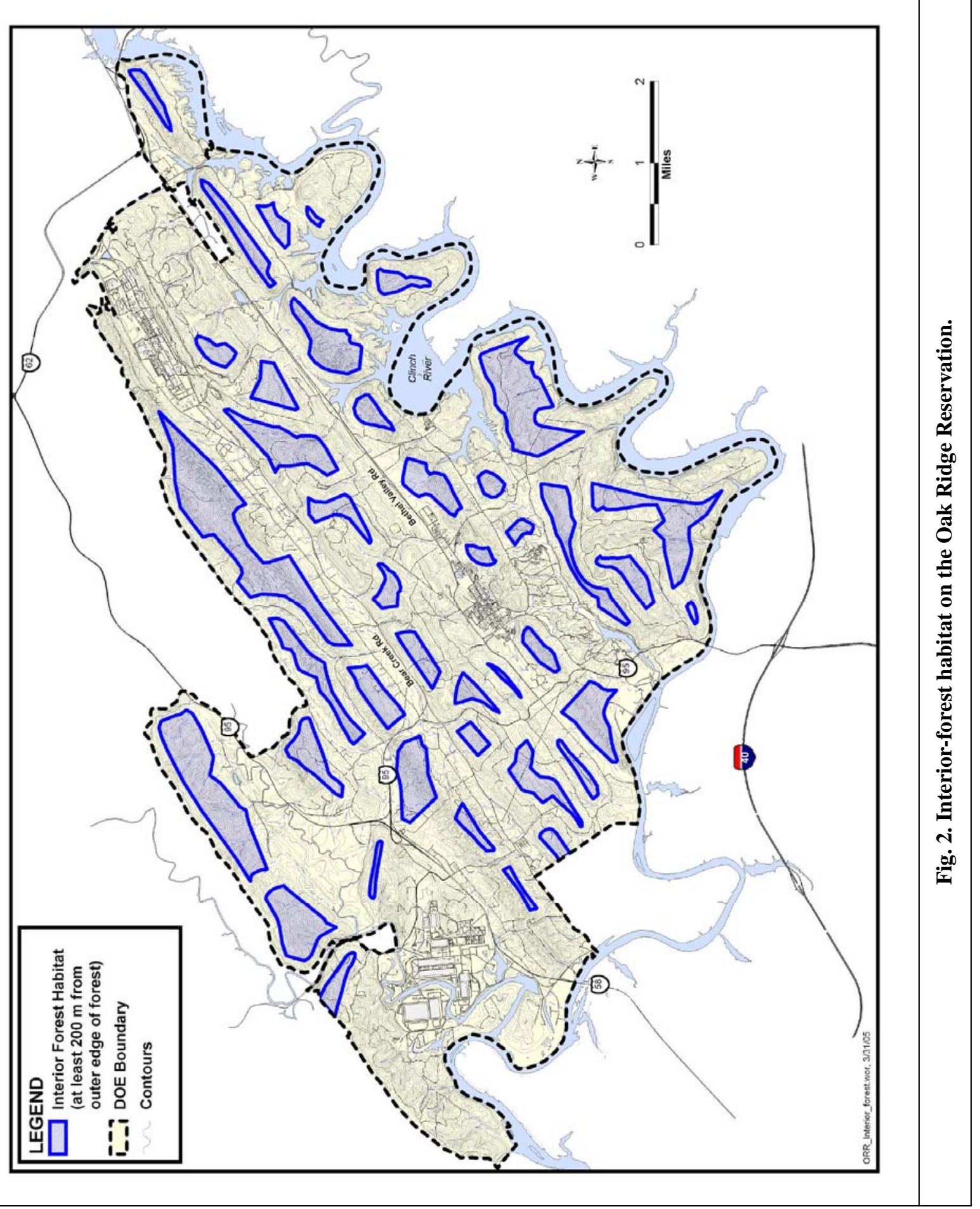


Studies conducted by wildlife biologist Stanley Temple indicate that the edge effect extends into a forest as much as $183 \mathrm{yd}(200 \mathrm{~m})$ (Temple and Cary 1988). Thus, researchers have used this distance as a criterion for identifying "interior" forest areas that would remain unaffected by forest fragmentation. When the 183-yd (200-m) buffer area is taken into consideration, the true nonimpacted interior forest can be eliminated or reduced to very small and/or narrow areas when encroached upon by surrounding roads, powerline corridors, and other openings. The ORR currently supports about 4100 acres (1659 ha) of interior forest. This acreage will decrease in certain areas of the Reservation with additional clearing for new buildings and roads and with further road-widening projects.

An important barometer in the determination of forest-habitat quality is the presence of certain neotropical migrant bird species. These species are impacted by decreases in acreage and by the fragmentation of forest habitats. Fortunately, the ORR continues to support many such species, including the Acadian flycatcher, the ovenbird, the hooded warbler, the northern parula, the Kentucky warbler, and the Louisiana waterthrush.

The continued fragmentation of forest habitat on the ORR would result in the loss of such species as those noted above. Forest fragmentation can be mitigated by careful road placement, minimizing road widenings, and allowing the forest canopy to close over existing roads where possible.

\subsection{DEFINITION OF WILDLIFE MANAGEMENT}

Wildlife management is the practice of integrating habitat requirements, wildlife population needs, and human interaction to maintain and enhance biodiversity, provide opportunities for human recreation, and protect public health and safety. Wildlife management is an interdisciplinary science. The diversity of wildlife species and their abundance results from the types and amount of habitat available and how they are influenced by human activity. Habitat can be managed to achieve a specific goal, or management can

result from manipulations through other land uses (e.g., waste management sites, clearing, utility right-ofway areas). The meaning of wildlife management is discussed further in Appendix F.

\section{WILDLIFE MANAGEMENT PLAN}

\subsection{GENERAL GOALS AND OBJECTIVES}

The overall goals of wildlife management on the ORR are as follows:

- $\quad$ to preserve healthy natural wildlife populations and habitat compatible with the DOE mission;

- $\quad$ to maintain and enhance wildlife biodiversity on the ORR;

- $\quad$ to integrate research, recreation, forest stewardship and other land-use practices with wildlife management objectives under multiple-use objectives; and

- $\quad$ to minimize wildlife damage to property and threats to public safety.

To accomplish these goals, management in the following areas is recommended (as permitted by resources and as mandated by the agreement between DOE and TWRA pursuant to the Sikes Act of 1974):

- $\quad$ wildlife habitat/species richness;

- $\quad$ featured habitats and species (including selected sensitive species);

- $\quad$ sensitive wildlife species inventory, protection, and restoration;

- $\quad$ game species, including hunting;

- $\quad$ wildlife problems (e.g., deer/vehicle collisions, Canada goose populations, other nuisance wildlife concerns); and

- $\quad$ nongame opportunities (e.g., bird walks, greenbelt enhancements). 
A summary of historical wildlife management activities on the ORR is contained in Appendix G.

\subsection{WILDLIFE-HABITAT MANAGEMENT}

The ORR is a premier site in the southeastern United States of relatively undisturbed, unfragmented, primarily natural habitat (TNC 1996). The major objective of this wildlife management plan is to maintain and preserve this regionally and nationally important refuge for wildlife diversity. There are, in addition, opportunities to improve general wildlife diversity on the ORR as follows:

- $\quad$ manage large fields for native grasses;

- $\quad$ promote forestry management techniques that benefit wildlife;

- $\quad$ maintain large, unbroken tracts of mature forest; and

- $\quad$ enhance featured habitats.

The above-mentioned goals would further define the objectives and methods for implementing the recommended practices. These habitat management measures contribute to species-richness management. Managing for species richness ensures that all wildlife species currently found on the ORR are maintained as residents in viable numbers. Each species, even those about which little or nothing is known (e.g., most invertebrates), is important. Preservation, development, and maintenance of a broad spectrum of habitats are long-term goals.

\subsection{FEATURED-SPECIES MANAGEMENT}

Featured habitats and species are those particularly important ecologically for introduction, restoration, or research. Management of such species can involve manipulating wildlife habitat, creating “artificial niches" (e.g., platforms, nesting boxes) within an appropriate habitat, or maintaining suitable habitat already present. Features of the habitat that might limit the species' use of that habitat can be restructured or enhanced so that conditions favor the species. This method is applicable to game, nongame, and sensitive wildlife species. The long-term goals of featured species management are to restore, reintroduce, or study species.

Four steps are involved in establishing the featured species/habitats program: (1) selecting species and habitats, (2) establishing habitat requirements of selected species, (3) determining management needs to create the desired habitat, and (4) conducting follow-up studies on the survival and establishment of the selected species and habitats. The following wildlife and associated habitat types are focal points for featured species management on the ORR through the identified mechanisms:

- $\quad$ wood duck through installation, maintenance, and monitoring of nest boxes;

- four-toed salamander through inventory and habitat protection;

- $\quad$ grasshopper sparrow through habitat restoration and maintenance;

- $\quad$ bald eagle through habitat protection;

- $\quad$ northern bobwhite through habitat maintenance and enhancement, with a potential future goal of translocation of the birds to other areas in the state;

- $\quad$ woodland bat species through inventory and habitat enhancement (forestry management practices);

- $\quad$ cave bat species through inventory and habitat protection;

- $\quad$ a yet-to-be-selected terrestrial invertebrate (e.g., lepidoptera or odonata) through inventory, habitat restoration, maintenance, and protection; and

- $\quad$ forest-area-sensitive neotropical birds through the implementation of clearing restrictions on projects that could cause habitat fragmentation. 


\subsection{GAME-SPECIES MANAGEMENT}

The goal of game-species management is to effectively combine public recreation with population control of game species (e.g., white-tailed deer, wild turkey, and Canada geese) for both ecological and public-health-and-safety reasons.

Active hunting programs for white-tailed deer and wild turkey act as the primary method of population control for these species on the ORR. Hunting is only one aspect of a multifaceted approach to Canada goose management on the ORR.

The success of the hunting program on the ORR is bolstered by the existence of hunting on adjacent parcels through agreements between TWRA and other entities. These adjacent parcels are also included under the Oak Ridge WMA, as defined by TWRA. The adjacent parcels include the following:

- $\quad$ Old Clinch River Breeder Reactor Site (managed by TWRA/Tennessee Valley Authority), which encompasses about 1500 acres (607 ha) (conducts deer and turkey hunts);

- University of Tennessee (UT) Forest Research and Education Center (managed by TWRA/UT), which encompasses about 2270 acres (919 ha) (conducts deer and turkey hunts); and

- $\quad$ Haw Ridge Park (managed by TWRA/City of Oak Ridge), which encompasses 770 acres (312 ha) (conducts deer hunts).

\subsubsection{White-tailed Deer Management}

The management and control of the white-tailed deer population on the ORR is critical in maintaining quality wildlife habitat and ensuring public safety. The impacts of deer overpopulation on habitat are well known. Heavy browsing by deer in overpopulated areas can result in significant impacts to understory growth, totally altering forest structure (Hough 1965; Ross, Bray, and Marshall 1970; Anderson and Loucks 1979; and Whitney 1984). Visible browse lines are evident in many areas of the ORR.

Deer/vehicle collisions have risen significantly in the United States in the past 30 or more years. Since the 1970s, the yearly deer/vehicle collisions in the United States have increased from approximately 200,000 to an estimated 500,000 in 1995. The National Safety Council Report estimated that in 1995 such collisions cost more than $\$ 125$ million in medical expenses, \$940 million in vehicle repairs, and \$350 million in wildlife loss. Besides being economically costly, deer/vehicle collisions are also a threat to people traveling the roads (Huges et. al. 1996). More recent figures released by the Insurance Institute for Highway Safety estimated that 1.5 million deer/vehicle collisions occur each year in the United States. These collisions result in at least $\$ 1.1$ billion in vehicle damage (Insurance Institute for Highway Safety News Release, November 18, 2004, available at http://www.iihs.org/news/2004/iihs_news_111804.pdf).

The rise in collisions on the ORR elevated concerns for public health and safety, which led to the decision to implement a public hunting program. Public deer hunts were initiated in the fall/winter of 1985 in an attempt to gain control of the burgeoning deer population and decrease the probability of deer/vehicle collisions. Since public hunting began, the number of deer/vehicle collisions has decreased (Fig. 3).

TWRA implemented a quality deer management (QDM) approach to the deer harvest on the ORR from 2003 through 2006. QDM is a strategy and philosophy that involves managing deer herds in a biologically and socially sound manner within existing habitat conditions. QDM encourages active participation in an antlerless deer harvest where appropriate and advocates protection of young bucks. The program is designed to protect yearling (1 1/2-year-old) bucks and many 21 /2-year-old bucks. This program is administered by restricting harvest to bucks with either four or more 1-in. $(2.54-\mathrm{cm})$ antler points on one side or an outside antler spread of $15 \mathrm{in} .(38 \mathrm{~cm})$ or larger. This program also allows the harvesting of does. A major objective of a sound deer management program is to establish and maintain a 1:1 adult sex ratio, which is achieved through a doe harvest. Where there are well-established deer populations, a general rule is to harvest one doe per 50 to 100 acres (20 to 40 ha) each year. The goal is to 


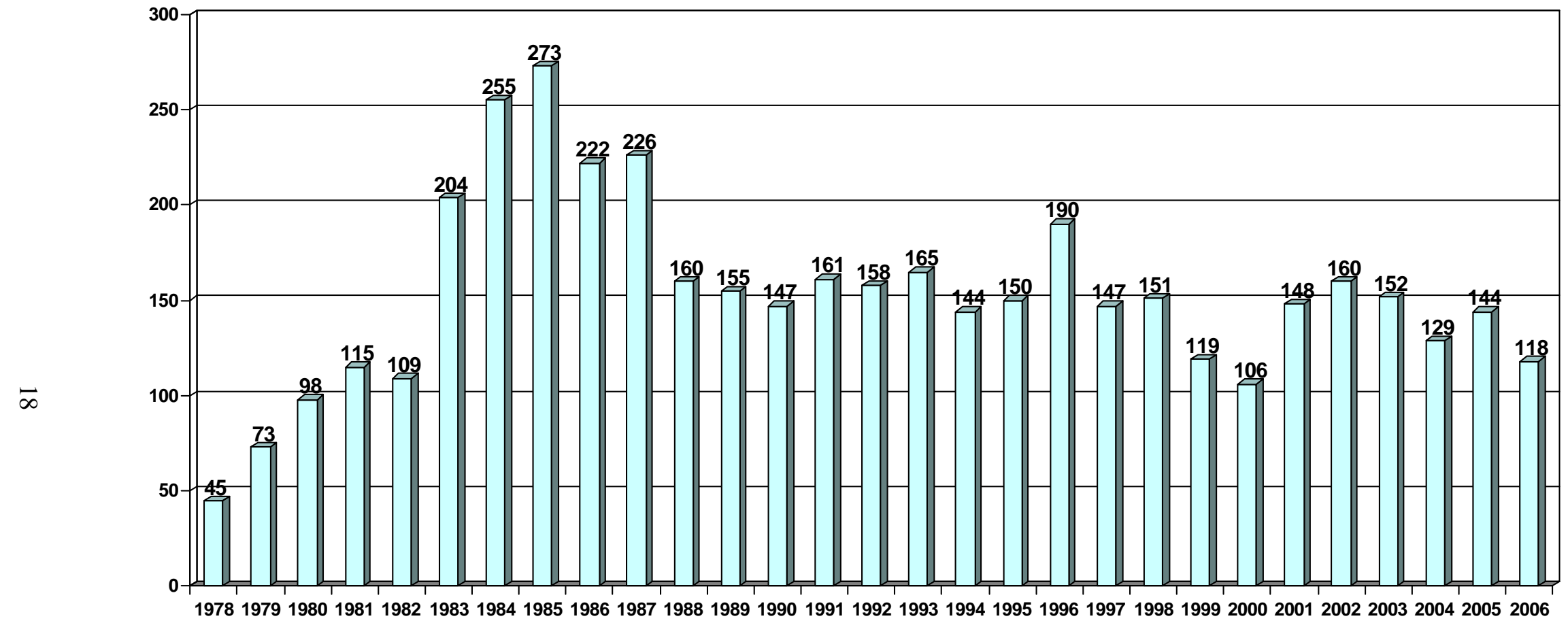

$\square$ Vehicle Killed Deer

Fig. 3. Deer/vehicle collisions on the Oak Ridge Reservation and vicinity. 
maintain a deer herd below carrying capacity and keep recruitment high. ORR restrictions under the QDM strategy allowed a hunter to harvest either one antlered and one antlerless or two antlerless deer per hunt for shotgun/muzzleloader hunters. Archery hunters were allowed to harvest three deer per hunt, with only one being antlered. The ORR will return to an either sex/no antler restriction strategy in 2007 to determine if harvest numbers can be increased to further decrease deer/vehicle collisions. The QDM approach will periodically be evaluated and management objectives adjusted as needed. Historical ORR harvest numbers are presented in Fig. 4.

Since 1994 the amount of huntable acreage on the ORR has been reduced by approximately 525 acres (212 ha). During this same time period, acreage open to gun (shotgun/muzzleloader) hunting has been reduced by approximately 5450 acres (2206 ha), 4700 acres (1902 ha) of which have been transferred to archery hunting. The main reason for these changes has been increased security requirements. The reduction in overall acreage for deer hunting coupled with increased acreage dedicated to archery hunting has presented greater challenges with regard to the management of the white-tailed deer population on the ORR. Large areas left unhunted, particularly at the Y-12 National Security Complex, and extensive interior areas at ORNL open to only archery hunting have resulted in localized population increases on certain parcels of land on the ORR. Large interior areas at ORNL open to only archery hunting results in less efficient harvesting in those areas. Historic hunt acreage totals are provided in Fig. 5. Management options under consideration to increase the deer harvest in currently inaccessible areas include the following:

- $\quad$ culling or trapping of deer within fenced locations and areas with high densities of buildings and/or people and

- $\quad$ hunting of specific parcels by badged employees only.

\subsubsection{Wild Turkey Management}

Public hunting of wild turkey was implemented in 1997 in conjunction with a plan to monitor this species for contaminant levels. Hunting was implemented because turkey numbers had dramatically increased on the ORR since the species' reintroduction in the mid- to late 1980s. From the approximately 40 turkeys originally restocked in 1985 and 1986, the population had grown to an estimated 600 to 1000 birds by 1996. Two spring (April) weekend hunts are conducted every year on the ORR for bearded turkeys only. Historical harvest numbers are contained in Fig. 6. Wild turkeys are relocated each year from the ORR to other areas in Tennessee that require restocking. This relocation is accomplished by trapping (i.e., using funnel-type cage traps and rocket netting).

\subsubsection{Canada Goose Management}

The USFWS published a final Record of Decision (ROD) and final rule regarding resident Canada goose management in August 2006. This ROD and final rule allow state wildlife agencies, landowners, and airports more flexibility in controlling resident Canada goose populations. This ruling strictly deals with resident populations and does not impact the protection afforded migratory geese under the MBTA and Executive Order 13186, Responsibilities of Federal Agencies to Protect Migratory Birds.

The ORR supports a large resident Canada goose population. These large nonmigratory flocks started to prosper in the area in the mid-1980s. Large areas of mowed turf associated with ponds and other water bodies have created prime habitat for this species. Canada goose management on the ORR involves a multifaceted approach that is mainly aimed at resolving nuisance concerns. A major obstacle is the inability to hunt this species in the areas of the Reservation where they tend to congregate. The majority of the goose population is found in the developed portion of the ORR around ponds and large areas of mowed grass. In these areas they cause health and safety concerns with their excessive droppings and 


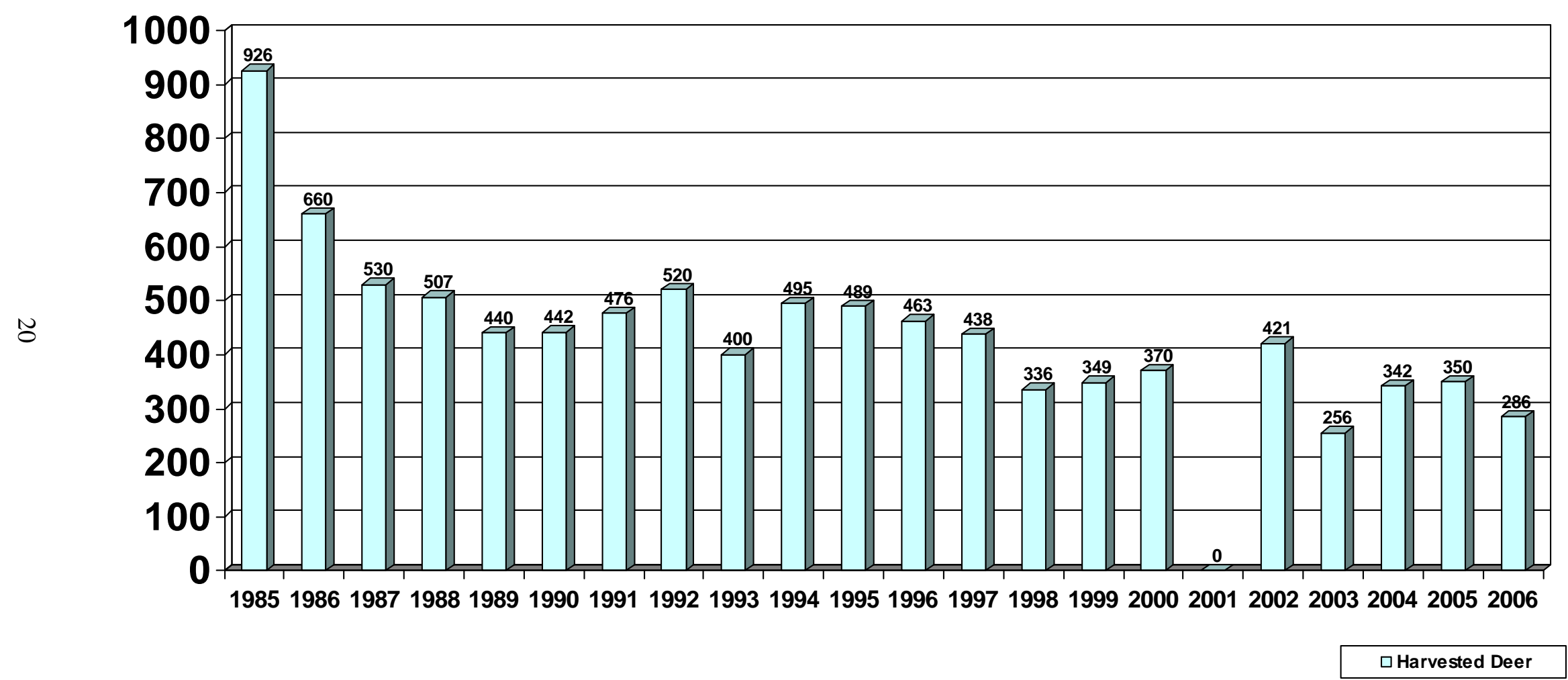

Fig. 4. Historical white-tailed deer harvest numbers for the Oak Ridge Reservation. 


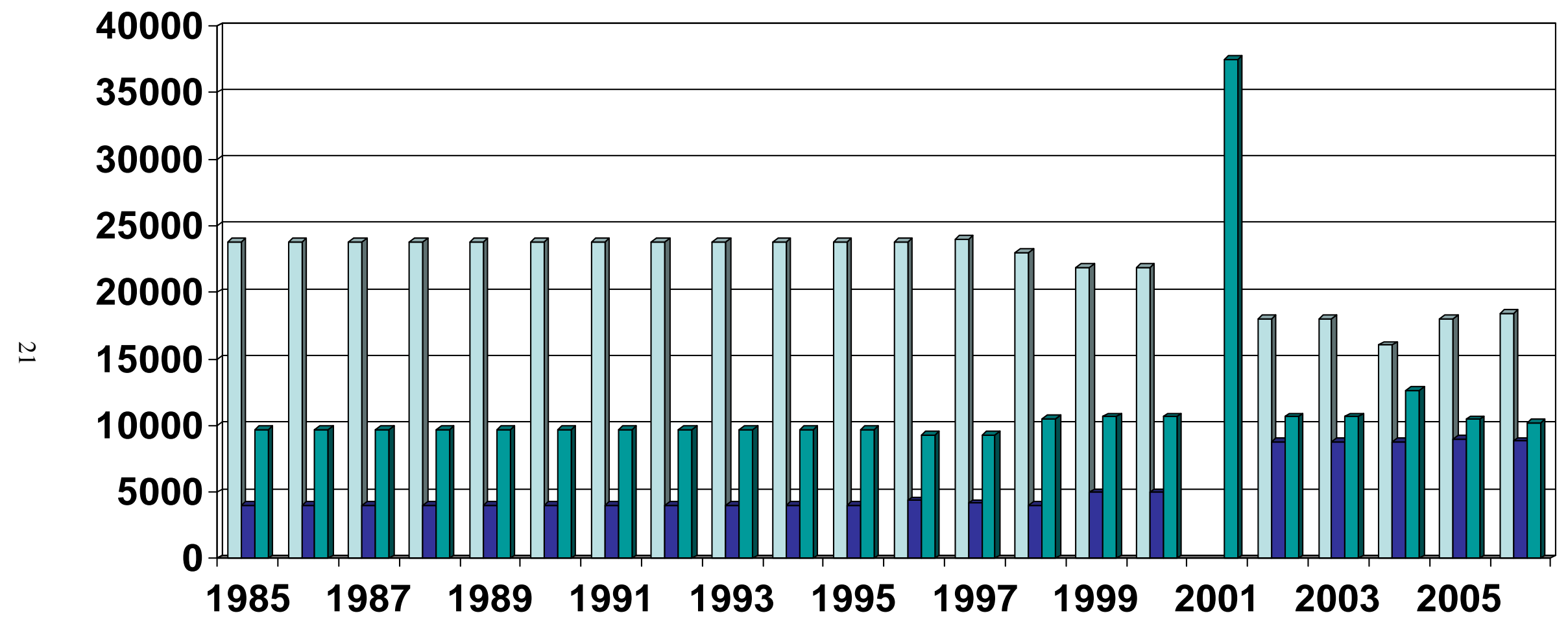

Fig. 5. Historical deer-hunting-acreage total for the Oak Ridge Reservation. 


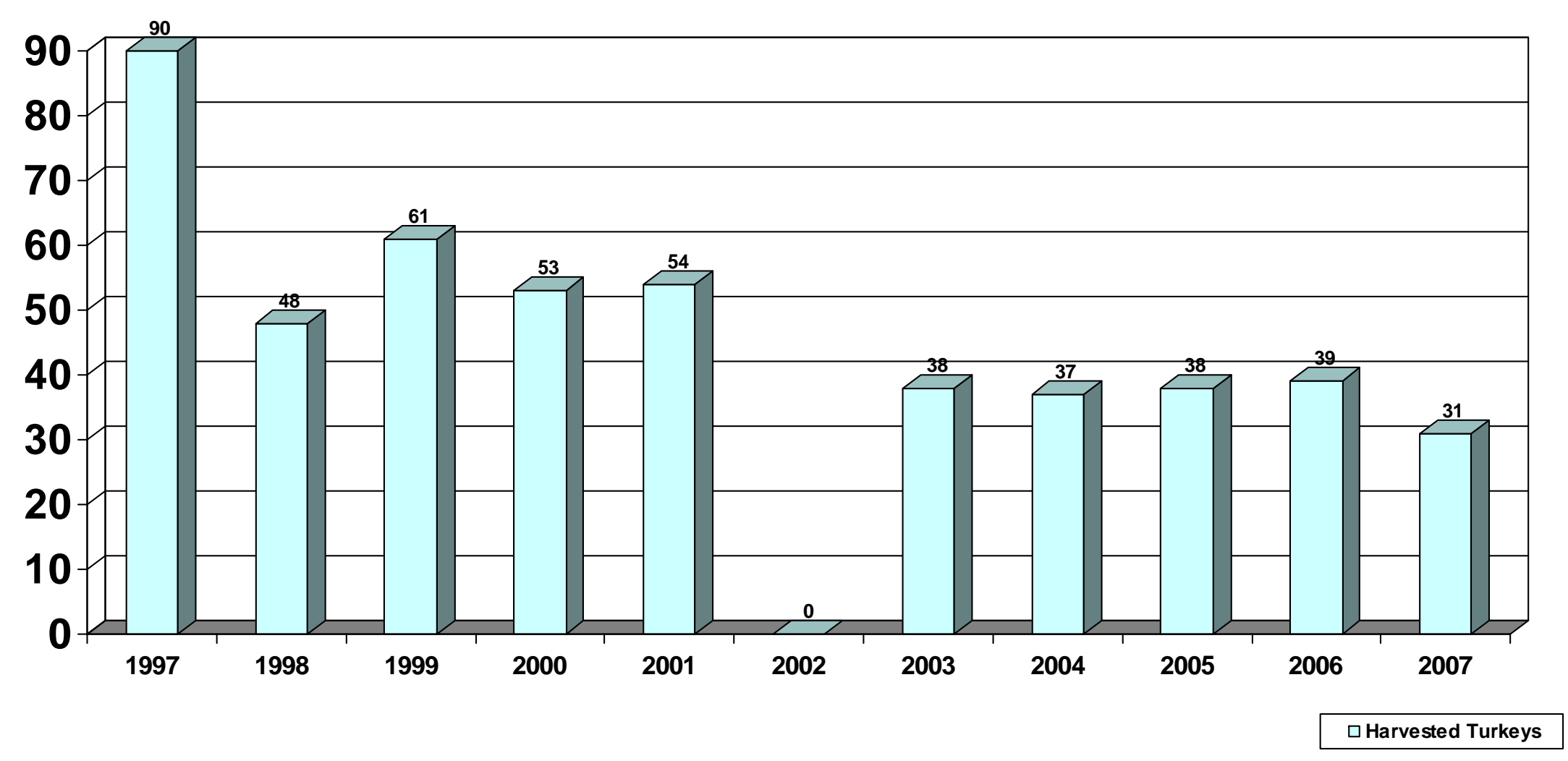

Fig. 6. Historical wild turkey harvest numbers for the Oak Ridge Reservation. 
sometimes aggressive behavior. The main methods currently being used to control Canada geese on the ORR are listed below.

- $\quad$ Egg addling/oiling and nest removal under a USFWS depredation permit. Trapping using funneltype cage traps.

- $\quad$ Relocation of geese to other areas in east Tennessee in concert with the annual summer ORR goose roundup. Relocations are done by the United States Department of Agriculture (USDA), Animal and Plant Health Inspection Service (APHIS)-Wildlife Services as permitted by the USFWS.

- Development of goose habitat in natural areas of the Reservation away from the main employee population. The main focus of habitat development is in the Three Bend Area.

- $\quad$ Hunting in the Three Bend Area.

The harassment of geese using border collies is a technique that will continue to be evaluated. This technique has been successful at golf courses, parks, and recreation areas and at corporate industrial parks. Other more advanced techniques (e.g., goose sterilization) will be fully evaluated for potential future use. Rocket netting of Canada geese will also be considered.

\subsection{MANAGEMENT OF THE THREE BEND SCENIC AND WILDLIFE MANAGEMENT REFUGE AREA}

TWRA manages the Three Bend Area through an agreement with DOE. Under that agreement, TWRA actively manages this approximately 3000-acre (1214-ha) area for the development of wildlife habitat. This area also acts as an important outdoor laboratory and educational facility. The following management activities are practiced on this site:

- $\quad$ management of native grasslands for both nongame and game species through seeding, mowing, and prescribed burns;

- $\quad$ establishment and management of habitat for Canada geese as part of the ORR overall goose management program;

- $\quad$ Canada goose and duck hunts in the area of established habitat;

- $\quad$ training of wildlife management students in trapping, wildlife damage control, bird identification, and other areas;

- $\quad$ summer outdoor education programs;

- $\quad$ community nature walks for public awareness of the natural resources of the area and management activities being undertaken;

- $\quad$ research on plants in an outdoor laboratory setting; and

- $\quad$ training of TWRA tracking dogs.

\subsection{NUISANCE WILDLIFE MANAGEMENT}

This document provides only an overview of nuisance wildlife management on the ORR. Please consult the Nuisance Wildlife Education and Prevention Plan for the Oak Ridge National Laboratory (Giffen 2006) for greater detail on nuisance wildlife issues and remedies. 


\subsubsection{Roles and Responsibilities}

\section{ORR Wildlife Management Coordinator}

The ORR Wildlife Management Coordinator provides advice and facilitates the resolution of nuisance wildlife management concerns on the Reservation.

\section{TWRA Wildlife Manager}

The TWRA wildlife manager responds to nuisance wildlife problems on an as-needed basis by providing advice, supplying traps, and picking up trapped animals for removal. TWRA's general duties do not include intensive nuisance wildlife trapping and responses.

\section{USDA, APHIS-Wildlife Services}

USDA, APHIS-Wildlife Services is typically called to respond to large-scale nuisance wildlife problems, along with those issues that require specialized methods and expertise.

\section{Facility}

Day-to-day nuisance wildlife control is the responsibility of the particular facility experiencing the problem, with guidance from the ORR Wildlife Management Coordinator and the TWRA wildlife manager as well as supplemental assistance from USDA, APHIS-Wildlife Services as needed.

\subsubsection{Protocol for Reducing Nuisance Wildlife Problems}

The following guidelines will reduce nuisance wildlife problems on the ORR:

- $\quad$ Do not transport wild and domestic animals from off-site on to the Reservation.

- $\quad$ Do not release nuisance wildlife trapped on the ORR to other areas. These animals should be euthanized. (Transport of animals off-site will only be done in certain special cases and under TWRA direction.) Any trapped feral cats should be taken to the animal shelter.

- $\quad$ Do not feed resident wildlife and feral cats on the ORR.

- $\quad$ Secure all dumpsters and other garbage receptacles to avoid providing a steady food supply to potential nuisance animals.

- Keep building maintenance up to date to prevent entry of animals through holes, broken windows, and other openings.

The justifications for adhering to the above guidelines are the following:

- $\quad$ Release of animals from other areas to the ORR will only increase the current problem.

- $\quad$ The feeding of resident wildlife and feral cats will provide a steady food supply, resulting in sustained and increased nuisance wildlife populations. It will also increase the chances of wildlife/human interactions that can cause health and safety concerns for the employees.

- $\quad$ The release of ORR nuisance wildlife to other areas can result in the increase of nuisance problems in that area (i.e., by transferring the problem to someone else), result in the spread of disease, and introduce "foreign" animals into a situation in which they might be unable to compete with resident animals for existing resources.

- $\quad$ USDA, APHIS-Wildlife Services requires euthanization rather than relocation of all raccoons and skunks trapped in east Tennessee counties because of concerns regarding the potential spread of rabies. 


\subsubsection{Nuisance Wildlife Management Issues around Facilities}

Nuisance wildlife issues around the facilities on the ORR are caused by a variety of species and typically fall into the following categories:

- $\quad$ nesting, denning or roosting inside buildings and

- $\quad$ entering dumpsters and other garbage receptacles in search of food.

The main mammals causing nuisance problems on the ORR are raccoons, skunks, opossums, and woodchucks (groundhogs). These nuisance animals can be handled with the use of baited live traps. The following baits are effective:

- $\quad$ raccoons: canned fish-flavored cat food, sardines, fish, and chicken;

- $\quad$ skunks*: canned fish-flavored cat food, peanut butter, sardines, and chicken entrails;

- $\quad$ opossums: cheese, slightly spoiled meat, fish, or fruit; and

- $\quad$ woodchucks: apple slices, vegetables such as carrots and lettuce, and pelletized rodent food.

*Note: When trapping for skunks, traps should be covered with canvas or other covering, which will have a calming effect on the skunk and reduce the chances of spraying. Traps are also commercially available that provide similar cover, eliminating the need to drape the trap with an outside covering.

Live traps can be obtained from the TWRA wildlife manager. The wildlife manager can also provide advice on baiting and the size of the trap to use. Once the animal has been trapped, TWRA will handle its removal. The employee should not handle the animal in any way because of the possibility of disease. TWRA wildlife managers are trained to handle these animals and are properly vaccinated against disease. USDA, APHIS-Wildlife Services will handle larger trapping efforts in which significant population reduction of nuisance animals is the goal.

\subsubsection{Nuisance Issues Requiring Special Skills}

\section{Beaver Control}

Beaver control and trapping are specialized skills; therefore, the TWRA wildlife manager will handle beaver-control measures in the ORR ponds and along the watercourses, as necessary. In general, control measures will be taken in situations in which dams are creating flooding concerns or associated nuisance problems. Only the TWRA wildlife manager and/or USDA, APHIS-Wildlife Services will perform beaver trapping and removal. The removal of dams and other debris resulting from beaver activity will be the responsibility of the appropriate ORR facilities and operations personnel.

\section{White-tailed Deer Nuisance Issues}

White-tailed deer can become a nuisance where they browse on ornamental shrubs and trees in campus areas. Deer can also become entrapped between buildings and behind fences. On rare occasions deer can become disoriented and run through windows and open doors. Nuisance problems with whitetailed deer must be addressed by personnel with specialized skills and the proper equipment and permits to handle any given situation. TWRA is the agency with purview over white-tailed deer management in the state. All ORR nuisance problems involving deer will be handled by TWRA, with assistance from the ORR Wildlife Management Coordinator. TWRA will also aid in the removal of deer from roadways where deer/vehicle collisions have occurred. 


\section{Prevention/Minimizing Exposure}

Efforts will be made to discourage use of ORNL facilities and areas by nuisance wildlife. Further details on the management and prevention of nuisance wildlife problems on the ORR are contained in the Nuisance Wildlife Education and Prevention Plan (Giffen 2006). The plan outlines certain preventative measures that can be taken to minimize the potential for nuisance wildlife problems on a species-specific basis.

Additional DOE funding was approved to expand nuisance wildlife control efforts on the ORR in FY 2007. A portion of this funding will be used to contract with USDA, APHIS-Wildlife Services. USDA, APHIS-Wildlife Services has significant experience in this area and holds the federal permits necessary to significantly expand upon the control methods that can be used on the ORR.

\subsubsection{Birds}

\section{Canada Geese}

Nuisance Canada goose concerns will be handled by the ORR Wildlife Management Coordinator in cooperation with the TWRA wildlife manager and USDA, APHIS-Wildlife Services. A multifaceted management approach has been established to address Canada goose nuisance wildlife concerns. The methods include those listed below.

- Implementation of a "no feeding” policy.

- Habitat modification to reduce preferred goose habitat.

- Landscaping to reduce palatable species and creation of physical barriers (in progress).

- Repellents.

- Dead goose decoys.

- Testing the feasibility of using trained dog(s) to flush geese away from unsuitable areas.

- Removal.

_ Egg destruction: Addling of goose eggs was initiated in the spring of 2005 under a USFWS permit. Sixty eggs were treated in 2005, 67 eggs in 2006, and 73 eggs in 2007.

- Roundup and relocation: Working through USDA, APHIS-Wildlife Services under a USFWS permit and with TWRA, 117 Canada geese were relocated to the Hiwassee Wildlife Refuge and the Chota Refuge in 2005, and 200 were relocated to the same areas in 2006. In 2007, 203 relocated ORR Canada geese were split between Kyles Ford Wildlife Management Area, Hiwassee Refuge, Chota Refuge, and a private landowner in Hancock County.

- Goose hunt: DOE approved the initiation of a goose hunt (pilot program) in the Three Bend Area in FY 2006. Hunts will be continued based on effectiveness, which will be evaluated on a yearly basis.

- $\quad$ Creation of goose habitat away from facilities: TWRA is establishing Canada goose habitat in the Three Bend Area using wheat, barley, and oats; some geese have already been relocated there, and the area is increasingly being used.

\section{Other Birds}

Birds such as swallows, house sparrows, starlings, and pigeons can become a nuisance with their propensity to nest and roost in and around buildings. Most bird nuisance concerns can be handled with modifications in building design and/or additional building maintenance. The ORR Wildlife Management Coordinator and the TWRA wildlife manager will provide advice on potential solutions to these bird nuisance problems. USDA, APHIS-Wildlife Services can be called in if significant problems require euthanasia of unprotected birds (i.e., house sparrows, starlings, and pigeons). 


\subsubsection{Snakes}

The copperhead is the only poisonous snake known to frequent the ORR. The copperhead is a pit viper and can be easily distinguished from nonpoisonous snakes by its elliptical pupils and face pits (located behind and below each nostril). The main nuisance complaints with snakes involve presence around and in buildings. Snakes are capable of accessing buildings through any gap/hole that is generally $1 / 4$ in. $(0.64 \mathrm{~cm})$ or larger. So, first and foremost, all gaps of that width or larger to the outside should be closed. In general, snakes will seek out cool, damp, dark areas where they can find food. They might be attracted to the outsides of buildings where there are low bushes and shrubs, rocks, boards, firewood piles, and debris lying on the ground. Anything that provides cover close to the ground can attract snakes. Therefore, if there is a snake problem, these types of situations should be evaluated where they occur in close proximity to buildings. Additionally, if there are any situations inside the building that might provide similar habitat (i.e., cool, damp, dark areas), that situation should be remedied wherever possible.

There are no registered toxicants or fumigants for snakes. Several repellents have been promoted, but none are consistently effective.

The ORR Wildlife Management Coordinator will respond to emergency snake nuisance concerns.

\subsubsection{Insects}

\section{Fire Ants}

The main nuisance insect on the ORR is the fire ant. Imported fire ants are reddish-brown to black and are $1 / 8$ to $1 / 4$ in. $(0.3$ to $0.6 \mathrm{~cm})$ long. They construct nests that are often most visible as dome-shaped mounds of soil, sometimes as large as $3 \mathrm{ft}(0.9 \mathrm{~m})$ across and $11 / 2 \mathrm{ft}(0.5 \mathrm{~m})$ in height. In general, mounds are 12 in. $(30.5 \mathrm{~cm})$ or more in diameter and height. In sandy soils, mounds are flatter and less visible. Fire ants usually build mounds in sunny, open areas such as lawns, pastures, cultivated fields and meadows, but they are not restricted to these areas. Mounds or nests can also be located in rotting logs, around trees and stumps, under pavement and buildings, and occasionally indoors. Fire ants are most notable at facilities in sparse grassy areas and along sidewalks and curbs. Ernest Ryan, the ORNL Field Environmental Compliance Representative, is responsible for recording the Global Positioning System locations and mapping of fire ant mounds on the ORR. Fire ant mounds are typically treated with chemical pesticides, and each facility is responsible for treatment on its area.

\section{Other Insects}

The majority of insect pest problems on the ORR are handled by either facilities personnel or contracted pest-control companies.

\subsection{SENSITIVE SPECIES INVENTORY, PROTECTION, AND MANAGEMENT}

Sensitive species are those specifically designated by federal, state, or other government agencies for protection or consideration. Sensitive species in Tennessee include federally listed endangered and threatened species, and species listed by the state of Tennessee as endangered, threatened, or in need of management. ORR wildlife managers also include those bird species recognized by PIF as being in decline in the southern ridge and valley. A list of sensitive species found on the ORR is presented in Table 1. The objective of sensitive-species management is to identify, protect, and preserve individual species and their habitats. The status of the sensitive plant species and the process by which they are identified and their habitats protected have been addressed in various ORR reports (Parr 1984; Parr and Pounds 1987; Cunningham et al. 1993). Sensitive animals are discussed by Roger Kroodsma in his article "Edge effect on breeding birds along power-line corridors in east Tennessee” (1987).

The results of surveys for sensitive species on the ORR are contained in recent reports (Mitchell et al. 1996). Continued monitoring of birds (e.g., bald eagle) and mammals (e.g., gray bat) and additional 
focus on reptiles and amphibians (e.g., four-toed salamander) are particularly important. Short-term objectives for management of sensitive species are to continue to maintain and update lists of all wildlife species on the ORR; to identify, through continued surveys, the rare wildlife that occur on the ORR; to determine habitat needs of listed or rare species; to provide protection of habitat through special protected area designation (e.g., Research Park Natural Area, State Natural Area); and to evaluate the need for initiating (if deemed necessary) active habitat management.

Current activities being undertaken to monitor sensitive species include the following:

- $\quad$ TWRA midwinter bald eagles counts,

- $\quad$ PIF surveys,

- Anabat acoustical surveys for bats,

- $\quad$ mist-net/harp-trap surveys for bats, and

- $\quad$ reptile and amphibian surveys.

Table 1 identifies sensitive wildlife species recently found on the ORR. Some of these (e.g., anhinga) have been seen only once or a few times; others (e.g., sharp-shinned hawk, southeastern shrew) are comparatively common and widespread on the Reservation.

Table 1. Wildlife species of concern reported for the Oak Ridge Reservation ${ }^{a}$

\begin{tabular}{|c|c|c|c|c|}
\hline \multirow{2}{*}{ Scientific name } & \multirow{2}{*}{ Common name } & \multicolumn{3}{|c|}{ Status $^{b}$} \\
\hline & & Federal & State & PIF $^{c}$ \\
\hline \multicolumn{5}{|c|}{ Fish } \\
\hline Phoxinus tennesseensis & Tennessee dace & & NM & \\
\hline & Amphibians and reptiles & & & \\
\hline \multirow[t]{2}{*}{ Hemidactylium scutatum } & Four-toed salamander & & NM & \\
\hline & Birds & & & \\
\hline Accipiter striatus & Sharp-shinned hawk & & NM & \\
\hline Anhinga anhinga & Anhinga & & NM & \\
\hline Caprimulgus carolinensis & Chuck-will's-widow & & & $\mathrm{C}$ \\
\hline Ardea alba & Great egret & & NM & \\
\hline Circus cyaneus & Northern harrier & & NM & \\
\hline Contopus cooperi & Olive-sided flycatcher & & NM & \\
\hline Dendroica caerulescens & Black-throated blue warbler & & & $\mathrm{C}$ \\
\hline Dendroica cerulea & Cerulean warbler & & NM & $\mathrm{C}$ \\
\hline Dendroica discolor & Prairie warbler & & & $\mathrm{C}$ \\
\hline Egretta caerulea & Little blue heron & & NM & \\
\hline Egretta thula & Snowy egret & & NM & \\
\hline Falco peregrinus & Peregrine falcon & $c$ & E & \\
\hline Haliaeetus leucocephalus & Bald eagle & & NM & \\
\hline
\end{tabular}


Table 1. (continued)

\begin{tabular}{|c|c|c|c|c|}
\hline \multirow{2}{*}{ Scientific name } & \multirow{2}{*}{ Common name } & \multicolumn{3}{|c|}{ Status $^{b}$} \\
\hline & & Federal & State & PIF \\
\hline Helmitheros vermivorus & Worm-eating warbler & & & $\mathrm{C}$ \\
\hline Hylocichla mustelina & Wood thrush & & & $\mathrm{C}$ \\
\hline Lanius ludovicianus & Loggerhead shrike & & NM & \\
\hline Oporornis formosus & Kentucky warbler & & & $\mathrm{C}$ \\
\hline Pooecetes gramineus & Vesper sparrow & & NM & \\
\hline Protonotaria citrea & Prothonotary warbler & & & $\mathrm{C}$ \\
\hline Seiurus motacilla & Louisiana waterthrush & & & $\mathrm{C}$ \\
\hline Sitta pusilla & Brown-headed nuthatch & & & $\mathrm{C}$ \\
\hline Sphyrapicus varius & Yellow-bellied sapsucker & & NM & \\
\hline Spizella pusilla & Field sparrow & & & $\mathrm{C}$ \\
\hline Tyto alba & Barn owl & & NM & \\
\hline Vermivora chrysoptera & Golden-winged warbler & & NM & $\mathrm{C}$ \\
\hline \multirow[t]{2}{*}{ Vermivora pinus } & Blue-winged warbler & & & $\mathrm{C}$ \\
\hline & Mammals & & & \\
\hline Myotis grisescens & Gray bat & $\mathrm{E}$ & $\mathrm{E}$ & \\
\hline Sorex longirostris & Southeastern shrew & & NM & \\
\hline
\end{tabular}

\subsection{WILDLIFE DISEASE MANAGEMENT}

\subsubsection{Rabies}

Potential rabies carriers on the ORR include raccoons, skunks, coyotes, and bats. There are no current records of rabies cases on the ORR; however, reports of sick animals are closely monitored, and animals are euthanized for testing when necessary. USDA, APHIS-Wildlife Services is the agency responsible for testing the animals, and it has established a mobile laboratory at the deer-check station on Bethel Valley Road. Any sick animals should be reported to either the TWRA wildlife manager or the ORR Wildlife Management Coordinator. 


\subsubsection{Pandemic Flu (Avian Influenza)}

\section{Monitoring}

Several state and federal agencies are monitoring birds for avian influenza in the United States. Monitoring of the local situation in the bird population will be done locally (on the ORR and surrounding area) by USDA, APHIS-Wildlife Services and TWRA. The ORR Wildlife Management Coordinator will maintain daily communication with these agencies. Sampling a variety of birds began in the summer of 2006. Samples include throat cultures and cloacal swabs. This enhanced surveillance includes collection along the Mississippi Flyway in western Tennessee (mallard, American wigeon, and other species) and resident bird collection (mourning dove, black vulture, Canada goose, rock pigeon, European starling, common grackle, wood duck, house sparrow, American crow, American robin, and various raptors).

\section{Preventing/Minimizing Exposure}

The active Canada goose population control program will aid in the reduction of geese on the ORR, thus minimizing exposure to the maximum extent possible. In addition, active trapping of rock pigeons and other nuisance birds on the ORR is to be undertaken in cooperation with TWRA and USDA, APHISWildlife Services. The contracting of USDA, APHIS-Wildlife Services allows for the broadening of nuisance-bird population control methods because of the wide scope allowed them through federal permitting. General control of nesting and roosting nuisance birds through building maintenance and the ORR no-feeding policy will also aid in reducing contact between people and birds around interior campus areas.

\section{Education}

TWRA will provide hunter information about avian flu in birds (e.g., precautions, awareness) for the ORR turkey hunts (April) and Canada goose hunts (September).

The ORR Wildlife Management Coordinator will continue to educate staff through presentations and information updates to ORNL Today (http://home.ornl.gov/general/ORNL_Today/).

\section{Handling Sick or Dead Birds}

If sick or dead birds are found on the ORR (particularly if found in groups), the TWRA wildlife manager or ORR Wildlife Management Coordinator should be contacted.

No reporting is necessary for birds that have died for obvious reasons (e.g., roadkills, collisions with windows). Of particular interest are groups of sick or dead birds. USDA, APHIS-Wildlife Services and TWRA will be issuing guidance to their staffs regarding handling of birds (even apparently healthy ones). Birds (dead or alive) should not be handled by untrained persons. TWRA and USDA, APHIS-Wildlife Services are trained to handle these birds, so those agencies will dispose of infected birds.

\section{PLANNED MANAGEMENT ACTIVITIES: FY 2007 TO FY 2012}

Projected activities for the wildlife management program FY 2007 through FY 2012 are as follows:

- $\quad$ annual public deer hunts;

- Canada goose roundup and relocation;

- $\quad$ Canada goose egg addling/oiling and nest destruction;

- $\quad$ Canada goose harassment activities;

- $\quad$ annual Canada goose hunts;

- $\quad$ annual mast surveys; 
- $\quad$ continuation of osprey monitoring program and powerline damage control;

- $\quad$ trapping and removal of wild turkey to stock other areas in the state;

- $\quad$ annual wild turkey hunts;

- $\quad$ wood duck census and hunts;

- implementation of recommendations from selective forest management study and forest fragmentation study to increase species diversity;

- $\quad$ evaluation and implementation of grassland management approaches;

- $\quad$ quail habitat enhancement;

- $\quad$ reptile and amphibian monitoring;

- $\quad$ bat surveys using mist nets, harp traps, and Anabat acoustical bat identification system;

- $\quad$ PIF surveys;

- $\quad$ bald eagle surveys;

- $\quad$ bald eagle habitat protection; and,

- $\quad$ public bird walks and other educational/recreational undertakings.

\section{REFERENCES}

Anderson, R. C., and O. L. Loucks. 1979. "White-tail deer (Odocoileus virginianus) influence on structure and composition of Tsuga canadensis forests.” Journal of Applied Ecology 16: 855-861.

Cunningham, M., L. Pounds, S. Oberholsler, P. Parr, L. Edwards, B. Rosensteel, and L. Mann. 1993. Resource Management Plan for the Oak Ridge Reservation, Volume 29: Rare Plants on the Oak Ridge Reservation. ORNL/NERP-7, Oak Ridge National Laboratory, Oak Ridge, TN.

DOE (Department of Energy). 1993. Integrating Natural Resource Damage Assessment and Environmental Restoration Activities at DOE Facilities. Office of Environmental Guidance, U.S. Department of Energy.

DOE (Department of Energy). 2006. Oak Ridge Reservation Annual Site Environmental Report for 2005. DOE/ORO/2218, U.S. Department of Energy.

Giffen, Neil. 2006. Nuisance Wildlife Education and Prevention Plan for the Oak Ridge National Laboratory. ORNL/TM-2006/154, Oak Ridge National Laboratory, Oak Ridge, TN.

Hough, A. F. 1965. "A twenty-year record of understory vegetational change in a virgin Pennsylvania forest.” Ecology 46: 370-373.

Huges, W. E., A. R. Saremi, and J. F. Paniati. 1996. "Vehicle-Animal Crashes: An Increasing Safety Problem.” ITE Journal 66(8): 24-28.

Kroodsma, R. L. 1987. "Edge effect on breeding birds along power-line corridors in east Tennessee.” American Midland Naturalist 118: 275-283.

Mann, L. K., P. D. Parr, L. R. Pounds, and R. L. Graham. 1996. "Protection of Biota on Nonpark Public Lands: Examples from the U.S. Department of Energy Oak Ridge Reservation.” Environmental Management 20: 207-218.

Mitchell, J. M., E. R. Vail, J. W. Webb, and J. W. Evans. 1996. Survey of Terrestrial Vertebrates on the Oak Ridge Reservation. ES/ES/TM-188/R1, Oak Ridge National Laboratory, Oak Ridge, TN. 
Parr, P. D. 1984. Resource Management Plan for the Oak Ridge Reservation, Volume 4: Endangered and Threatened Plant Species. ORNL-6026/V4, Oak Ridge National Laboratory, Oak Ridge, TN.

Parr, P. D., and J. F. Hughes. 2006. Oak Ridge Reservation Physical Characteristics and Natural Resources. ORNL/TM-2006/110, Oak Ridge National Laboratory, Oak Ridge, TN.

Parr, P. D., and J. W. Evans. 1992. Resource Management Plan for the Oak Ridge Reservation, Volume 27: Wildlife Management Plan. ORNL/NERP-6, Oak Ridge National Laboratory, Oak Ridge, TN.

Parr, P. D., and L. R. Pounds. 1987. Resource Management Plan for the Oak Ridge Reservation, Volume 23: Oak Ridge National Environmental Research Park, Research Sites, and State Natural Areas. ORNUESH-1/V23, Oak Ridge National Laboratory, Oak Ridge, TN.

Parr, P. D., M. G. Ryon, H. D. Quarles, N. R. Giffen, M. S. Salk, and J. W. Webb. 2004. Invasive Plant Management Plan for the Oak Ridge Reservation. ORNL/TM-2004/98, Oak Ridge National Laboratory, Oak Ridge, TN.

Pounds, L. R., P. D. Parr, and M. G. Ryon. 1993. Resource Management Plan for the Oak Ridge Reservation, Volume 30: Oak Ridge National Environmental Research Park Natural Areas and Reference Areas-Oak Ridge Reservation Environmentally Sensitive Sites Containing Special Plants, Animals, and Communities. ORNL/NERP-8, Oak Ridge National Laboratory, Oak Ridge, TN.

Ross, B. A., J. R. Bray, and W. H. Marshall. 1970. "Effects of long-term deer exclusion on a Pinus resinosa forest in north-central Minnesota.” Ecology 51: 1088-1093.

Temple, S. A., and J. R. Cary. 1988. "Modeling dynamics of habitat-interior bird populations in fragmented landscapes.” Conservation Biology 2: 340-347.

TNC (The Nature Conservancy). 1995. The Oak Ridge Reservation, Biodiversity and the Common Ground Process. Final report. Available at http://www.esd.ornl.gov/facilities/nerp/orr_tnc.pdf.

Washington-Allen, R. A., T. L. Ashwood, S. W. Christensen, H. Offerman, and P. ScarbroughLuther. 1995. Terrestrial Habitat Mapping of the Oak Ridge Reservation: Phase 1. ES/ER/TM-152, Oak Ridge National Laboratory, Oak Ridge, TN.

Whitney, G. G. 1984. "Fifty years of change in the arboreal vegetation of Heart's Content, an old growth hemlock-white pine-northern hardwood stand.” Ecology 65: 403-408. 


\section{APPENDIX A}

MEMORANDUM OF UNDERSTANDING BETWEEN THE UNITED STATES FISH AND WILDLIFE SERVICE, DEPARTMENT OF THE INTERIOR, AND THE DEPARTMENT OF ENERGY REGARDING IMPLEMENTATION OF EXECUTIVE ORDER 13186, “RESPONSIBILITIES OF FEDERAL AGENCIES TO PROTECT MIGRATORY BIRDS”

AND

SELECTED PORTIONS OF EXECUTIVE ORDER 13186 

6450-01-P

DEPARTMENT OF ENERGY

Memorandum of Understanding Between the United States Fish and Wildlife Service, Department of the Interior, and the Department of Energy Regarding Implementation of Executive Order 13186, "Responsibilities of Federal Agencies to Protect Migratory Birds."

AGENCIES: Department of Energy and United States Fish and Wildlife Service, Department of the Interior.

ACTION: Notice of availability of Memorandum of Understanding.

SUMMARY: The Department of Energy (DOE) and the Department of the Interior (DOI), United States Fish and Wildlife Service (FWS) have entered into a Memorandum of Understanding (MOU), effective August 3, 2006. The purpose of the MOU is to address how both Parties may cooperatively handle migratory bird protection and conservation in accordance with the requirements of the Migratory Bird Treaty Act (MBTA) and Executive Order (EO) 13186.

FOR FURTHER INFORMATION CONTACT: John Stirling, U.S. Department of Energy, 1000 Independence Avenue, S.W. (Room 3G-092), Washington, D.C. 20585, 202-586-2417 
SUPPLEMENTARY INFORMATION: The MOU addresses how DOE and DOI may cooperatively handle migratory bird protection and conservation and ensure that DOE operations are consistent with the requirements of the Migratory Bird Treaty Act (MBTA) and Executive Order (EO) 13186, "Responsibilities of Federal Agencies to Protect Migratory Birds." EO 13186 specifically directs Federal agencies whose actions have, or are likely to have, a measurable negative impact on migratory bird populations, to incorporate migratory bird conservation measures into their activities. The MOU serves to strengthen migratory bird protection and conservation through enhanced collaboration between DOE and FWS, and fulfills DOE's obligation under EO 13186. The MOU identifies specific areas in which cooperation between DOE and FWS will substantially contribute to the conservation and management of migratory birds and their habitats. The MOU establishes protocols to provide the necessary guidance for DOE to incorporate migratory bird protection and conservation more fully into its programs in accordance with EO requirements.

The complete text of this MOU is available for view on the following Department of Energy web site: www.eh.doe.gov/oepa/data

Issued at Washington, D.C. October 30, 2006

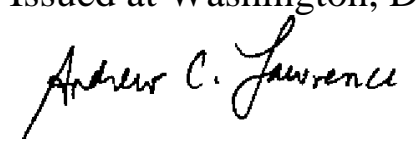

Andrew C. Lawrence

Director

Office of Nuclear Safety and Environment Office of Health, Safety and Security U.S.

Department of Energy 
Memorandum of Understanding

Between the United States Department of Energy

And the United States Fish and Wildlife Service

Regarding Implementation of Executive Order 13186,

"Responsibilities of Federal Agencies to Protect Migratory Birds"

Prepared by:

United States Department of Energy

and

United States Fish and Wildlife Service 



\section{Table of Contents}

Purpose

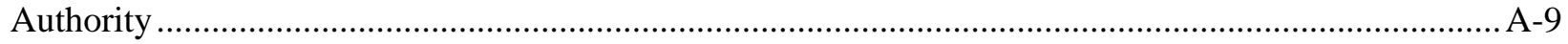

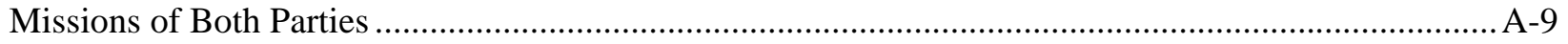

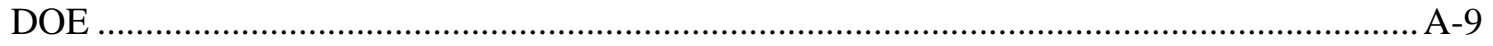

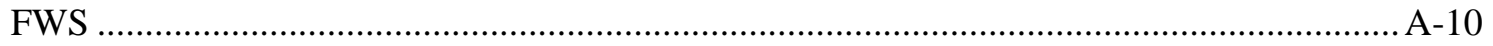

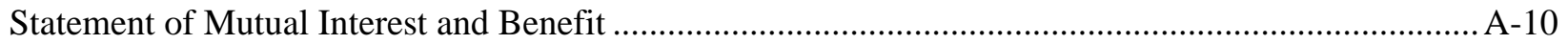

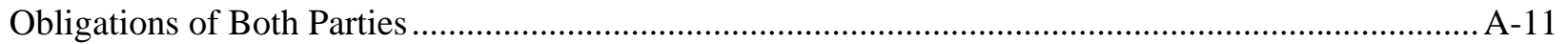

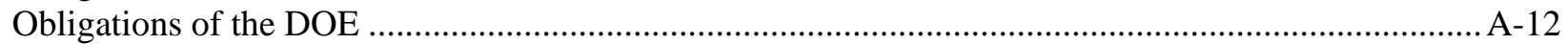

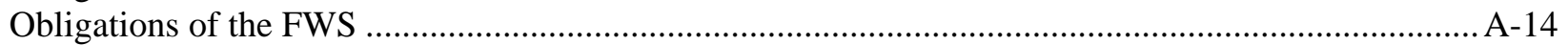

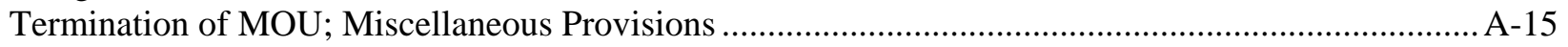

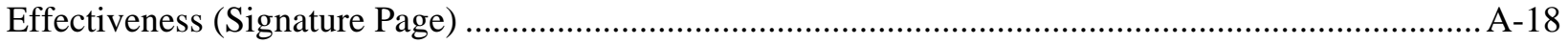

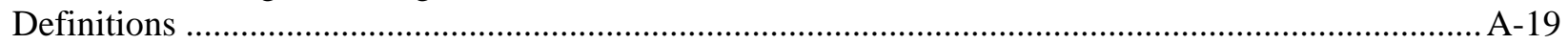





\section{Memorandum of Understanding Between the United States Department of Energy and the United States Fish and Wildlife Service Regarding Implementation of Executive Order 13186, "Responsibilities of Federal Agencies to Protect Migratory Birds"}

This Memorandum of Understanding (MOU) is entered into by and between the United States Department of Energy (DOE) and the United States Department of the Interior, Fish and Wildlife Service (FWS), herein collectively referred to as the Parties.

\section{A. Purpose}

This MOU meets the requirements under Section 3 of Executive Order 13186 (66 FR 3853, January 17, 2001), concerning the responsibilities of Federal agencies to protect migratory birds. The Executive Order directs executive departments and agencies to take certain actions to protect and conserve migratory birds. The purpose of this MOU is to strengthen migratory bird conservation through enhanced collaboration between DOE and the FWS, in coordination with state, tribal, and local governments. This MOU does not remove the Parties' legal requirements under the Migratory Bird Treaty Act and does not authorize the take of migratory birds. This MOU identifies specific areas in which cooperation between the Parties will substantially contribute to the conservation and management of migratory birds and their habitats.

\section{B. Authority}

This MOU is entered under the provisions of the following laws and other authorities available to the Parties:

Migratory Bird Treaty Act (16 U.S.C. §§ 703-711)

Bald and Golden Eagle Protection Acts (16 U.S.C. §§ 668-668d)

Fish and Wildlife Coordination Act (16 U.S.C. §§ 661-666c)

The National Environmental Policy Act of 1969 (42 U.S.C. §§ 4321-4347)

The Endangered Species Act of 1973 (16 U.S.C. §§ 1531-1544) Executive

Order 13186 (66 FR 3853)

\section{Missions of Both Parties}

\section{$\underline{\text { DOE }}$}

The mission of DOE is to enhance national security through fostering domestic energy production, energy efficiency, and the development of alternative energy sources; ensuring the safety and integrity of the Nation's nuclear weapons; advancing nuclear non-proliferation; cleaning up the environmental legacy of the Cold War and permanently disposing of radioactive waste; and leading in the physical sciences and advancing the biological, environmental, and computational sciences. 
The National Nuclear Security Administration (NNSA) is a semi-autonomous agency within DOE reporting directly to the Deputy Secretary of Energy. NNSA has oversight responsibility for several Department of Energy field sites that would be impacted by this MOU. All responsibilities described in this MOU that pertain to DOE also apply to NNSA.

\section{FWS}

The mission of the FWS is to work with others to conserve, protect, manage, and enhance fish, wildlife, plants, and their habitats for the continuing benefit of the American people. The FWS Migratory Bird Program serves as a focal point in the United States for policy development and strategic planning, program implementation, and evaluation of actions designed to conserve migratory birds and their habitats.

The FWS is legally mandated to implement the conservation provisions of the Migratory Bird Treaty Act (16 U.S.C. § 703 et seq.), which includes responsibilities for migratory bird population management (e.g., monitoring), habitat protection (e.g., acquisition, enhancement, and modification), international coordination, and regulations development and enforcement.

\section{Statement of Mutual Interest and Benefit}

DOE manages approximately 2.28 million acres of land, of which a substantial amount is undeveloped and includes wetlands, deserts, and forested mountain areas that provide habitat for a variety of wildlife, including many species of migratory birds. DOE takes its environmental stewardship role seriously and advocates a proactive management stance toward the natural environment. Migratory birds are a part of the natural and man-made environment at many DOE sites, and proper management of migratory birds on DOE lands fosters healthy and diverse species. DOE recognizes that some of its activities have the potential to affect migratory birds (e.g., operation of transmission lines, power poles, and waste-water retention and evaporation ponds; management of invasive weeds; and various construction activities). To lessen the impacts on migratory birds, whenever appropriate and feasible, DOE sites utilize avian-friendly transmission lines and power poles that are designed to minimize bird collisions and electrocutions; sponsor avian workshops with federal and private entities on minimizing electrocutions and collisions on electric utility structures; monitor waste water retention and evaporation ponds and when necessary utilize netting or noise devices to discourage migratory bird use; utilize invasive weed eradication practices that pose minimal risks to migratory birds; reseed areas with desirable plant species to encourage migratory bird use; monitor construction projects and when feasible schedule construction activities after nesting seasons; and develop habitat management plans for various bird species including bald eagle, Mexican spotted owl, wood stork, and southwestern flycatcher. In addition, DOE routinely utilizes the National Environmental Policy Act (NEPA) process to evaluate the potentially significant environmental impact of proposed actions, including impacts to migratory birds, and to examine alternatives to those actions. 
Both Parties have interests and responsibilities in the conservation and management of America's natural heritage and natural resources. The Parties agree that migratory birds are important components of biological diversity, that their conservation and management will help to sustain ecological integrity, and they serve the growing public demand for outdoor recreation, conservation education, wildlife viewing, and hunting opportunities.

This MOU is necessarily general due to the diversity of programs throughout the DOE site complex.

In consideration of these premises, the Parties agree as follows:

\section{E. Obligations of Both Parties}

To the extent allowed by law, subject to the availability of appropriations and within Administration budgetary limits, and in harmony with DOE and FWS missions and capabilities, both Parties shall:

1. Protect, restore, enhance and manage habitats of migratory birds, to the fullest extent practicable. This includes:

a. Implementing management practices that minimize or avoid adverse impact on migratory bird populations, and their nesting, migration, or over-wintering habitats.

b. Working collaboratively with Federal and State agencies to identify, protect, restore, enhance, monitor, and manage important migratory bird areas.

c. Preventing or abating the pollution or detrimental alteration of the environment of migratory birds.

2. Promote collaborative inventorying, monitoring, management studies, research, and information exchange related to the conservation of migratory birds and management of their habitats. This includes:

a. Sharing inventory, monitoring, research, and study data for breeding, migrating, and wintering populations and habitats in a timely fashion with national repositories (such as BBIRD and MAPS); other Federal and State agencies, as appropriate; and among DOE offices, as practicable.

b. Collaborating, as practicable, in management studies and research to identify the habitat conditions needed by migratory bird species, sustain populations of coexisting species, and understand the effects of management activities on them,

c. Developing partnerships with other agencies and non-Federal entities to further bird conservation, as practicable. 
3. Identify and pursue training opportunities for appropriate employees in methods of monitoring bird populations for the purposes of inventorying, measuring demographic parameters, and evaluating the effects of land management activities; and implementing land use practices that promote bird conservation.

4. Provide representation on the Council for the Conservation of Migratory Birds.

5. Periodically evaluate the measures taken under this MOU to protect, restore, and enhance migratory bird resources, including avoiding or minimizing take of migratory birds and, if necessary, suggesting revisions to the FWS to ensure that the most effective conservation measures are employed. These efforts will he coordinated through the FWS's Division of Migratory Birds.

\section{F. Obligations of the DOE}

To the extent allowed by law, subject to the availability of appropriations and within Administration budgetary limits, and in harmony with the Department's missions and capabilities, the DOE shall:

1. Integrate migratory bird conservation principles, measures, and practices into agency activities. Avoid or minimize, to the extent practicable, adverse impacts on migratory bird resources when conducting agency actions, in compliance with, and supporting the purposes of, the Migratory Bird Treaty Act, the Bald and Golden Eagle Protection Act, the Endangered Species Act, NEPA, and other applicable statutes.

2. Protect, restore, enhance, and manage habitats of migratory birds, to the fullest extent practicable. This includes:

a. Reviewing FWS migratory bird lists and/or conducting field surveys to determine which species occur or are likely to occur on DOE properties;

b. Developing habitat management plans to benefit migratory birds and other species consistent with individual DOE site programs;

c. Restoring and enhancing migratory bird and other species' habitat consistent with individual DOE site programs. This may include restoring wetland habitat, controlling invasive species (both plant and animal), reseeding with desirable plant species, etc.;

d. Preventing and abating the pollution or detrimental alteration of migratory bird habitat by: 
i. Properly managing hazardous wastes associated with site activities by containerizing, storing, transporting, or burying wastes in accordance with applicable regulations and guidelines;

ii. Timely remediation of areas that have been contaminated with hazardous materials/wastes;

iii. Using controlled burning to manage invasive weeds; and

iv. Using physical, mechanical, and/or herbicidal treatments that pose minimal risks to migratory birds to control invasive weeds; and

e. Ensuring that migratory bird protection and conservation is considered in NEPA project reviews by:

i. Identifying and evaluating the effects of proposed projects (actions) on migratory birds;

ii. Minimizing adverse impacts on migratory birds by evaluating all reasonable alternatives of a proposed action; and

iii. Providing reasonable measures within a proposed action to eliminate or minimize adverse effects on migratory bird species. If DOE determines that significant adverse effects to migratory birds cannot be avoided or minimized, the DOE site will notify the FWS prior to the start of the proposed action.

3. Incorporate migratory bird habitat and population management objectives and recommendations into planning processes, including DOE site planning documents, as appropriate, in cooperation with federal, state, and tribal agencies.

4. Promote appropriate programs and recommendations of comprehensive migratory bird planning efforts such as Partners in Flight, United States Shorebird Conservation Plan, North American Waterfowl Management Plan, North American Colonial Waterbird Conservation Plan, and other planning efforts, within established authorities and in conjunction with the adoption, amendment, or revision of agency management plans and guidance.

5. Obtain permits from the applicable FWS Regional Migratory Bird Permit Offices for the take of migratory birds pursuant to requirements of 50 CFR $\S \S 10,13,21$, and 22. Doing so shall serve as advance notice to the FWS that DOE is conducting an action that is likely to result in the take of migratory birds.

6. Identify where take reasonably attributable to DOE actions, other than permitted activities referenced in paragraph 5 above, could affect migratory bird populations or habitats, focusing first on species of concern, their habitats, and key risk factors associated with DOE activities (e.g., installation of power poles and transmission 
lines, construction projects, invasive weed species eradication, and waste treatment that utilizes retention and evaporation ponds).

a. With respect to those actions so identified, and where appropriate and feasible, DOE shall develop and use principles, standards, and practices that lessen the amount of takings. This includes:

i. Utilizing avian-friendly transmission lines and power poles;

ii. Scheduling construction activities around migratory bird nesting seasons;

iii. Utilizing netting covers on waste-water retention and evaporation ponds;

iv. Sponsoring avian workshops on minimizing electrocutions and collisions on electric utility structures; and

v. Following the recommendations and suggested practices in wind turbine and powerline guidelines published by FWS and the Avian Power Line Interaction Committee, respectively, to minimize impacts from existing facilities and in the construction of new utility and energy systems and associated infrastructure.

b. DOE shall inventory and monitor bird populations and habitats, as appropriate and feasible, to facilitate decisions about the need for, and effectiveness of, conservation efforts.

7. Recognize and promote the ecological, economic and recreational values of migratory birds into outreach and educational materials and activities.

8. Advise the public of this MOU through a notice published in the Federal Register.

\section{G. Obligations of the FWS}

Unless otherwise specified, the following activities will be coordinated through the Regional Migratory Bird Program.

To the extent permitted by law and subject to the availability of appropriations and Administration budgetary limits, and to the extent that the following obligations are in harmony with agency missions and capabilities, the FWS shall:

1. Work to identify special migratory bird habitats (e.g., migration corridors, stop-over habitats, nesting habitats) under the stewardship of DOE. 
2. Improve cooperation and coordination with DOE and other Federal agencies, State agencies, universities, and independent nongovernmental organizations involved in monitoring and research efforts that provide reliable information on the status and trends of migratory bird populations.

3. Provide assistance, at the request of DOE, to identify particular species and habitats that would benefit most from particular agency land management decisions.

4. Initiate new or provide greater support for long-term research and monitoring programs of birds on DOE and adjacent lands.

5. The Division of Migratory Birds shall keep DOE informed of the latest directions in bird conservation that might affect DOE activities, lands, or policies, by providing information on:

a. Changes to the Migratory Bird Treaty Act and its regulations and procedures, or other acts and their regulations affecting migratory birds;

b. Population trends of species that might be affected by activities on DOE lands;

c. Changes to the list of Birds of Conservation Concern;

d. Changes in, updates to, or additions to national and regional bird conservation plans (e.g., Partners in Flight bird conservation plans, United States Shorebird Conservation Plan, North American Waterbird Conservation Plan, and the North American Waterfowl Management Plan); and

e. Updated protection measures for reducing human-caused bird mortality as new information becomes available.

6. Encourage widespread use of the best available scientific information in the management of migratory bird populations.

7. Conduct informational and educational programs for DOE oriented toward migratory bird conservation.

\section{H. Termination of MOU; Miscellaneous Provisions It}

is mutually agreed and understood that:

This MOU in no way alters or diminishes any Party's obligations or responsibilities under any statute or other legal authority. 
1. Either Party may terminate this MOU, in whole or in part, at any time before the date of expiration by providing the other Party 30 days written notice to that effect.

2. Changes to this MOU shall be made by means of written modification(s) bilaterally executed by the Parties. This instrument in no way alters a Party's obligations to conduct environmental analyses, including compliance with NEPA requirements.

3. This MOU in no way restricts either Party from participating in similar activities with other public or private agencies, governments, organizations, or individuals.

4. Documents furnished to a Party under this MOU may be subject to the Freedom of Information Act (FOIA, 5 U.S.C. § 552). A Party shall not release documents originating in the other Party to a FOIA requester. Rather, the Party shall forward such document(s) to the originating Party for review, determination, and response directly to the requester.

5. Modification of this MOU maybe made by the issuance of a written amendment(s), signed and dated by all Parties.

6. This is not a binding contract but is an MOU, which broadly states basic understandings between the Parties hereto of the tasks and methods for performing the tasks, described herein. The details of the levels of support to be furnished to one organization by the other with respect to funding shall be developed in specific interagency agreements or other agreements, subject to the availability of funds. This MOU shall not be used to obligate or commit funds or as the basis for the transfer of funds. This instrument does not establish authority for noncompetitive award of any contract or other agreement. Any contract or agreement for training or other service must fully comply with all applicable requirements for competition.

7. Any press releases that reference this MOU, or the relationship established between the Parties of this MOU, shall have prior approval of both Parties.

8. Periodic meetings of the Parties shall be scheduled to review progress and identify opportunities for advancing the understandings in this MOU. Collaboration under this MOU shall be in accordance with the applicable statutes and regulations governing the respective Parties.

9. In the event that a dispute arises between the Parties, whether programmatic or procedural, that could have clear, identifiable negative impacts for migratory birds covered by this MOU, the DOE site representative(s) responsible for administering this MOU and their FWS counterpart(s) shall contact DOE's Office of Dispute Resolution and/or FWS's Bureau Dispute Resolution Specialist, who will advise the Parties in determining whether a dispute resolution process, such as convening a mediation with a skilled, experienced mediator, would be appropriate. If 
resolution can not be reached at the local level, either Party can elevate the issue to the appropriate officials at DOE and FWS Regional offices. In the event that there is no resolution at the Regional levels, the Parties may elect to elevate the dispute to the Washington, D.C. office of each agency.

10. This MOU does not require changes to current contracts, permits, or other third party agreements. The MOU recognizes that DOE may not be able to implement some elements of the MOU until such time as DOE has successfully included them in formal planning processes.

11. This MOU is intended only to improve the internal management of the Executive Branch of the Federal Government and does not create any right or benefit, substantive or procedural, separately enforceable at law or equity by a party against the United States, its agencies or instrumentalities, its officers or employees, or any other person.

12. The principal contacts for this MOU are as follows:

Leroy Banicki

Office of Air, Water and Radiation

Protection Policy and. Guidance

U.S. Department of Energy

Room 3G-089

1000 Independence Ave., SW

Washington, D.C. 20585
Brian Millsap, Chief

Division of Migratory Bird Management

U.S. Fish and Wildlife Service

U.S. Department of the Interior

4401 N. Fairfax Drive,

MS 4107

Arlington, VA 22203 
1. Effectiveness

1. This Memorandum of Understanding Between the United States Department of Energy and the United States Fish and Wildlife Service Regarding Implementation of Executive Order 13180, "Responsibilities of Federal Agencies to Protect Migratory Birds" shall become effective as of the date the last Party duly executes it below.

2. This MOU shall be effective for five years as of the last date signed below, unless extended or terminated in writing by the Paries.

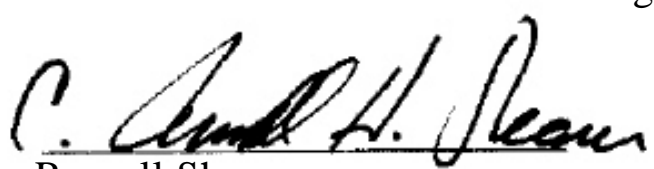

Russell Shearer

Acting Assistant Secretary for

Environment, Safety and Health

U.S. Department of Energy

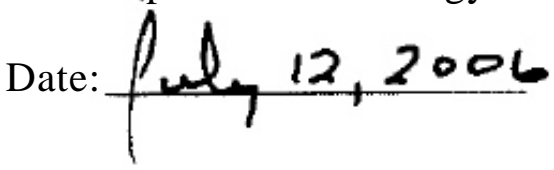

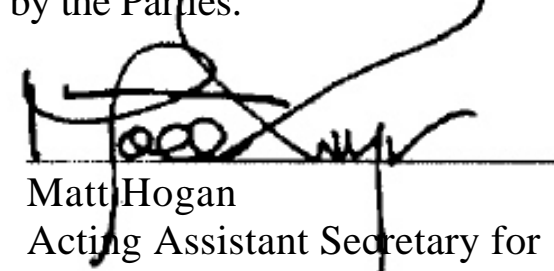

Fish, Wildlife and Parks

U.S. Department of Interior

JUN 122006

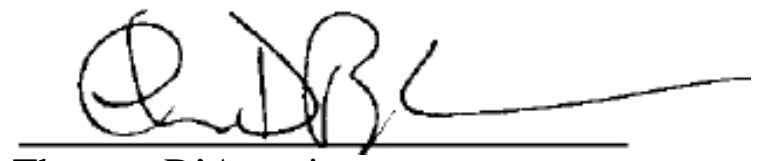

Thomas D'Agostino

Deputy Administrator for Defense Programs

National Nuclear Security Administration

Date: August 3, 2006

A-18 


\section{Appendix}

Definitions

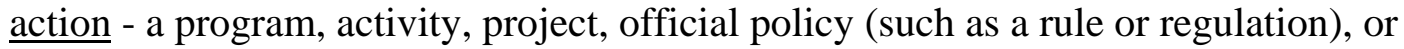
formal plan directly carried out by a Federal agency.

Birds of Conservation Concern - published by the Fish and Wildlife Services' Division of Migratory Bird Management, refers to the list of migratory and non-migratory birds of the United States and its Territories that are of conservation concern. The most current version of the list, Birds of Conservation Concern 2002, is available at http://migratorybirds.fws.gov/reports/bcc2002.pdf

Breeding Biology Research and Monitoring Database (BBIRD) - national, cooperative program that uses standardized field methodologies for studies of nesting success and habitat requirements of breeding birds (pica.wru.umt.edu/BBIRD/)

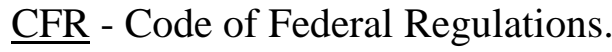

intentional take - take that is the purpose of the activity in question.

migratory bird - an individual of any species protected by the Migratory Bird Treaty Act. A list of migratory birds can be found in 50 CFR $\S 10.13$, Code of Federal Regulations (www.gpoaccess.gov/cfr/).

Monitoring Avian Productivity and Survivorship (MAPS) - a voluntary-based program that uses the banding of birds during the breeding season to track the changes and patterns in the number of young produced and the survivorship of adults and young (www.birdpop.org/maps.htm).

North American Waterbird Conservation Plan (NAWCP) - a coalition of Federal and State government agencies, non-governmental organizations, and private interests focusing on the conservation of waterbirds, primarily marsh birds and colonial waterbirds (www.waterbirdconservation.org/pubs/ContinentalPlan.cfm ).

North American Waterfowl Management Plan (NAWMP) - a coalition of Federal and State government agencies, non-governmental organizations, and private interests focusing on the conservation of waterfowl (www.fws.gov/birdhabitat/NAWMP/index.shtm).

National Environmental Policy Act (NEPA) - requires Federal agencies to prepare a detailed analysis of the environmental impacts of their proposal and alternatives and to include public involvement in the decision making process for actions significantly affecting the quality of the human environment. 
Partners in Flight (PIF) - a coalition of more than 300 partners including Federal and State government agencies, non-governmental organizations, conservation groups, foundations, universities, and industry focusing on the conservation of land birds (www.partnersinflight.org).

site - a geographic entity comprised of land and the improvements thereon owned or leased by or for the account of the Federal government and under the control of DOE.

species of concern - refers to those species listed in the periodic report, Birds of Conservation Concern, published by the FWS Division of Migratory Bird Management (migratorybirds.fws.gov/reports/speccon/tblconts.html); priority migratory bird species documented in the comprehensive bird conservation plans (North American Waterbird Conservation Plan, United States Shorebird Conservation Plan, Partners in Flight Bird Conservation Plans); species or populations of waterfowl identified as high, or moderately high, continental priority in the North American Waterfowl Management Plan; listed threatened and endangered bird species in 50 CFR 17.11; and MBTA listed game birds below desired population sizes

(http://www.fws.gov/migratorybirds/reports/reports.html)

take - as stated in 50 CFR $\S 10.12$ to include pursue, hunt, shoot, wound, kill, trap, capture, or collect, or to attempt to pursue, hunt, shoot, wound, kill, trap, capture, or collect.

United States Shorebird Conservation Plan (USSCP) - an effort undertaken by a partnership of Federal and State government agencies, non-governmental organizations, and private entities to ensure stable and self-sustaining populations of all shorebird species are restored and protected (www.fws.gov/shorebirdplan/). 


\section{SELECTED PORTIONS OF EXECUTIVE ORDER 13186}

Sec. 3. Federal Agency Responsibilities. (a) Each Federal agency taking actions that have, or are likely to have, a measurable negative effect on migratory bird populations is directed to develop and implement, within 2 years, a Memorandum of Understanding (MOU) with the Fish and Wildlife Service (Service) that shall promote the conservation of migratory bird populations.

(b) In coordination with affected Federal agencies, the Service shall develop a schedule for completion of the MOUs within 180 days of the date of this order. The schedule shall give priority to completing the MOUs with agencies having the most substantive impacts on migratory birds.

(c) Each MOU shall establish protocols for implementation of the MOU and for reporting accomplishments. These protocols may be incorporated into existing actions; however, the MOU shall recognize that the agency may not be able to implement some elements of the MOU until such time as the agency has successfully included them in each agency's formal planning processes (such as revision of agency land management plans, land use compatibility guidelines, integrated resource management plans, and fishery management plans), including public participation and NEPA analysis, as appropriate. This order and the MOUs to be developed by the agencies are intended to be implemented when new actions or renewal of contracts, permits, delegations, or other third party agreements are initiated as well as during the initiation of new, or revisions to, land management plans.

(d) Each MOU shall include an elevation process to resolve any dispute between the signatory agencies regarding a particular practice or activity.

(e) Pursuant to its MOU, each agency shall, to the extent permitted by law and subject to the availability of appropriations and within Administration budgetary limits, and in harmony with agency missions:

(1) support the conservation intent of the migratory bird conventions by integrating bird conservation principles, measures, and practices into agency activities and by avoiding or minimizing, to the extent practicable, adverse impacts on migratory bird resources when conducting agency actions;

(2) restore and enhance the habitat of migratory birds, as practicable;

(3) prevent or abate the pollution or detrimental alteration of the environment for the benefit of migratory birds, as practicable;

(4) design migratory bird habitat and population conservation principles, measures, and practices, into agency plans and planning processes (natural resource, land management, and environmental quality planning, including, but not limited to, forest and rangeland planning, coastal management planning, watershed planning, etc.) as practicable, and coordinate with other agencies and nonfederal partners in planning efforts;

(5) within established authorities and in conjunction with the adoption, amendment, or revision of agency management plans and guidance, ensure that agency plans and actions promote programs and recommendations of comprehensive migratory bird planning efforts such as Partners-in-Flight, U.S. National Shorebird Plan, North American Waterfowl Management Plan, North American Colonial Waterbird Plan, and other planning efforts, as well as guidance from other sources, including the Food and Agricultural Organization's International Plan of Action for Reducing Incidental Catch of Seabirds in Longline Fisheries;

(6) ensure that environmental analyses of Federal actions required by the NEPA or other established environmental review processes evaluate the effects of actions and agency plans on migratory birds, with emphasis on species of concern;

(7) provide notice to the Service in advance of conducting an action that is intended to take migratory birds, or annually report to the Service on the number of individuals of each species of migratory birds intentionally taken during the conduct of any agency action, including but not limited to banding or marking, scientific collecting, taxidermy, and depredation control;

(8) minimize the intentional take of species of concern by: (i) delineating standards and procedures for such take; and (ii) developing procedures for the review and evaluation of take actions. 
With respect to intentional take, the MOU shall be consistent with the appropriate sections of 50 CFR. parts 10, 21, and 22;

(9) identify where unintentional take reasonably attributable to agency actions is having, or is likely to have, a measurable negative effect on migratory bird populations, focusing first on species of concern, priority habitats, and key risk factors. With respect to those actions so identified, the agency shall develop and use principles, standards, and practices that will lessen the amount of unintentional take, developing any such conservation efforts in cooperation with the Service. These principles, standards, and practices shall be regularly evaluated and revised to ensure that they are effective in lessening the detrimental effect of agency actions on migratory bird populations. The agency also shall inventory and monitor bird habitat and populations within the agency's capabilities and authorities to the extent feasible to facilitate decisions about the need for, and effectiveness of, conservation efforts;

(10) within the scope of its statutorily-designated authorities, control the import, export, and establishment in the wild of live exotic animals and plants that may be harmful to migratory bird resources;

(11) promote research and information exchange related to the conservation of migratory bird resources, including coordinated inventorying and monitoring and the collection and assessment of information on environmental contaminants and other physical or biological stressors having potential relevance to migratory bird conservation. Where such information is collected in the course of agency actions or supported through Federal financial assistance, reasonable efforts shall be made to share such information with the Service, the Biological Resources Division of the U.S. Geological Survey, and other appropriate repositories of such data (e.g., the Cornell Laboratory of Ornithology);

(12) provide training and information to appropriate employees on methods and means of avoiding or minimizing the take of migratory birds and conserving and restoring migratory bird habitat;

(13) promote migratory bird conservation in international activities and with other countries and international partners, in consultation with the Department of State, as appropriate or relevant to the agency's authorities;

(14) recognize and promote economic and recreational values of birds, as appropriate; and

(15) develop partnerships with non-Federal entities to further bird conservation.

(f) Notwithstanding the requirement to finalize an MOU within 2 years, each agency is encouraged to immediately begin implementing the conservation measures set forth above in subparagraphs (1) through (15) of this section, as appropriate and practicable. 


\section{APPENDIX B}

SELECTED PORTIONS OF DOE ORDER 450.1, ENVIRONMENTAL PROTECTION PROGRAM, CHANGE 2 (DECEMBER 7, 2005) 



\section{SELECTED PORTIONS OF DOE ORDER 450.1, ENVIRONMENTAL PROTECTION PROGRAM, CHANGE 2 (DECEMBER 7, 2005)}

1. OBJECTIVES. To implement sound stewardship practices that are protective of the air, water, land, and other natural ... resources impacted by ... DOE operations and by which DOE cost effectively meets or exceeds compliance with applicable environmental; public health; and resource protection laws, regulations, and DOE requirements. This objective must be accomplished by implementing Environmental Management Systems (EMSs) at DOE sites. An EMS is a continuing cycle of planning, implementing, evaluating, and improving processes and actions undertaken to achieve environmental goals. These EMSs must be part of Integrated Safety Management Systems (ISMSs) ....

\section{APPLICABILITY.}

a. DOE Elements.

(1) ..., this Order applies to all DOE elements ... that are responsible for the management and operation of the Department's facilities, including elements of the National Nuclear Security Administration and power administrations.

\section{b. DOE Contractors.}

The Contractor Requirements Document (CRD), Attachment 2, sets forth requirements of this Order that will apply to contractors responsible for the management and operation of the Department-owned facilities whose contracts include the CRD.

(1) This CRD must be included, as appropriate, in all site/facility management contracts involving activities associated with the use, storage, disposal and transportation of waste; emissions to air; discharges to water; and management of ... other natural resources.

\section{REQUIREMENTS.}

a. General Requirements. All DOE elements must ensure that site ISMSs include an EMS that does the following.

(1) Provides for the systematic planning, integrated execution, and evaluation of programs for-

(c) compliance with applicable environmental protection requirements.

(2) Includes policies, procedures, and training to identify activities with significant environmental impacts, to manage, control, and mitigate the impacts of these activities, and to assess performance and implement corrective actions where needed.

(3) Includes measurable environmental goals, objectives, and targets that are reviewed annually and updated when appropriate.

b. Integration of an EMS into ISMS. As part of integrating EMSs into site ISMSs, DOE elements must do the following.

(1) Consider the following for inclusion as applicable:

(d) protection of other natural resources including biota,

(e) protection of site resources from wildland and operational fires,....

(2) Promote the long-term stewardship of a site's natural ... resources throughout its operational, closure, and post-closure life cycle.

5. RESPONSIBILITIES. All DOE elements ... are responsible for implementing the requirements specified in paragraph 4. ... Specific responsibilities for implementing this Order are set forth below.

d. DOE Operations/Field/Site Office Managers, ... in coordination with their reporting sites and PSOs, must do the following.

(4) Incorporate, where appropriate, environmentally and economically beneficial landscape practices into all new landscaping programs, policies, and practices for facilities under their purview, in furtherance of compliance with Executive Order 13148. 
(7) Ensure site annual budgetary processes include the funding and resources needed to implement this Order, ...

(14) Conduct environmental monitoring, as appropriate, to support the site's ISMS, to detect, characterize, and respond to releases from DOE activities; assess impacts; estimate dispersal patterns in the environment; characterize the pathways of exposure to members of the public; characterize the exposures and doses to individuals, to the population; and to evaluate the potential impacts to the biota in the vicinity of the DOE activity.

(15) Ensure the analytical work supporting environmental monitoring is implemented using-

(a) a consistent system for collecting, assessing, and documenting environmental data of known and documented quality. 


\section{SELECTED PORTIONS OF ATTACHMENT 2: CONTRACTOR REQUIREMENTS DOCUMENT TO DOE O 450.1, ENVIRONMENTAL PROTECTION PROGRAM}

Regardless of the performer of the work, contractors with this Contractor Requirements Document (CRD) incorporated into their contracts are responsible for (1) compliance with the requirements of the CRD and (2) flowing down the requirements of the CRD to subcontracts at any tier to the extent necessary to ensure the contractors' compliance with the requirements.

This CRD requires contractors to integrate numerous environmentally related requirements already placed on it by existing statutes, regulations, and policies through the use of an Environmental Management System (EMS) incorporated into an Integrated Safety Management System (ISMS). EMS requirements must be addressed in the contractor's ISMS ....

Contractors must:

1. General Requirements. Ensure their integrated safety management systems (ISMSs) include environmental management systems (EMSs) that do the following.

(a) Provide for the systematic planning, integrated execution, and evaluation of programs for-

(1) public health and environmental protection, .... and

(3) compliance with applicable environmental protection requirements.

(b) Include policies, procedures, and training to identify activities with significant environmental impacts, to manage, control, and mitigate the impacts of these activities, and to assess performance and implement corrective actions where needed.

(c) Include measurable environmental goals, objectives, and targets that are reviewed annually and updated when appropriate.

2. Integration of an EMS into ISMS. As part of integrating EMSs into their ISMSs, do the following.

(a) Consider the following for inclusion as applicable:

(4) protection of other natural resources including biota,

(5) protection of site resources from wildland and operational fires ...

(b) promote the long-term stewardship of a site's natural ... resources throughout its operational, closure, and post-closure life cycle; ....

(c) ensure the early identification of, and appropriate response to, potential adverse environmental impacts associated with DOE operations, including as appropriate, preoperational characterization and assessment; and effluent and surveillance monitoring.

6. Incorporate, where appropriate, environmentally and economically beneficial landscape practices into all new landscaping programs, policies, and practices for facilities. [See requirements placed on Federal agencies in Executive Order 13148, Greening the Government Through Leadership in Environmental Management.]

10.Conduct environmental monitoring, as appropriate, to support the site's ISMSs, to detect and characterize releases from DOE activities; assess impacts; estimate the dispersal patterns in the environment; characterize the pathways of exposure to members of the public; and characterize the exposures and doses to individuals, and to the population; and to evaluate the potential impacts to the biota in the vicinity of the DOE activity. 



\section{SELECTED PORTIONS OF ATTACHMENT 3: POLLUTION PREVENTION [P2] AND SUSTAINABLE ENVIRONMENTAL STEWARDSHIP GOALS TO DOE O 450.1, ENVIRONMENTAL PROTECTION PROGRAM}

\section{PURPOSE.}

c. To integrate pollution prevention and sustainable environmental stewardship into DOE operations as a cost-effective business practice that will:

(2) protect environmental resources,....

2. GOALS, OBJECTIVES AND STRATEGIES.

The Department herein establishes five performance-based P2 and Sustainable Environmental Stewardship goals that are to be achieved by DOE sites through the integration of P2 into environmental management systems pursuant to DOE 450.1 and its Contractor Requirements Document (CRD). The accompanying strategies for achieving the P2 and Sustainable Environmental Stewardship goals are to be considered for inclusion in sites' environmental management systems, as applicable or otherwise appropriate. DOE sites are also to consider mission performance and life-cycle costs when selecting specific strategies for achieving the P2 and Sustainable Environmental Stewardship goals.

GOAL-PROTECT THE ENVIRONMENT AND ENHANCE MISSION ACCOMPLISHMENT THROUGH REDUCTION OF ENVIRONMENTAL RELEASES

OBJECTIVE-Reduce environmental hazards, protect environmental resources, ... by eliminating or minimizing the use of toxic chemicals and associated releases of pollutants to the environment that would otherwise require control, treatment, monitoring, and reporting.

\section{STRATEGIES-}

- Based on OAs, establish objectives and measurable targets in site EMSs for minimizing the use of toxic chemicals, and reducing associated releases of pollutants to the environment (air, water, soil, biota).

GOAL-PROTECT THE ENVIRONMENT AND ENHANCE MISSION ACCOMPLISHMENT THROUGH INCORPORATION OF ENVIRONMENTAL STEWARDSHIP IN PROGRAM PLANNING AND OPERATIONAL DESIGN

OBJECTIVE_-Reduce environmental hazards, conserve environmental ... resources, ... by incorporating sustainable environmental stewardship in the commissioning of site operations and facilities.

\section{STRATEGIES-}

- Establish sustainable environmental stewardship objectives and measurable targets in site environmental management systems (EMSs).

- Green Landscaping

- Implement cost-effective, sustainable landscape design and management practices to reduce adverse impact to the natural environment and native ecological systems.

- Identify resources needed to implement this sustainable environmental stewardship goal and sitespecific objectives and targets in site annual budgetary processes. 



\section{APPENDIX C}

\section{OUTLINE OF SELECTED PARTS OF THE TENNESSEE}

LAWS RELATED TO WILDLIFE 



\section{TENNESSEE CODE ANNOTATED}

Title 70, Wildlife Resources

Chapter 4, "Miscellaneous Regulations”

Part 1-Hunting and Fishing

70-4-101. Ownership and title to wildlife vested in the state.

70-4-102. Illegal taking, possession or destruction of wildlife-Penalty for violations.

70-4-103. Fox hunting-Training of hunting dogs-Penalty.

70-4-104. Catching or killing fish-Fishing regulations.

70-4-105. Lawful possession of wildlife by legal license holders.

70-4-106. Permission of owner of land to take wildlife or big game required-Penalty for violations.

70-4-107. Hunting and fishing seasons-Bag and creel limits-Nonprotected wildlife.

70-4-108. Hunting from or across public road or near dwelling-Penalty.

70-4-109. Hunting from aircraft, watercraft or motor vehicles unlawful-Penalty-Exception for persons confined to wheelchairs.

70-4-110. Spotlighting deer-Penalty.

70-4-111. Hunting or killing any big game during closed season-Penalty.

70-4-112. Hunting and chasing coons regulated-Training season-Violations-Penalties.

70-4-113. Use of bait, pitfalls and certain other devices in taking birds and animals prohibitedPenalty-Exceptions.

70-4-114. Destruction of dens or nests-Spotlighting-Use of spears, explosives, chemicals or other devices unlawful-Penalty.

70-4-115. Destruction and disposal of wildlife-Permit-Penalty.

70-4-116. Hunting, killing and possession of deer, bear, wild elk, wild boar and wild turkeyTransporting-Tagging-Penalties.

70-4-117. Possession of weapons in areas inhabited by big game-Penalty.

70-4-118. Unlawful to hunt deer being chased by dogs or to permit dogs to hunt or chase deerConfiscation of dogs-Penalties. 
70-4-119. Taking of aquatic animal life other than game fish-Possession of commercial fishing gear on contaminated waters-Use of explosives, electrical devices or poisons in taking fish-Penalties.

70-4-120. Trapping, snaring or baiting regulations-Penalties for violations-Snare traps-Use of tamed quail to train bird dogs.

70-4-121. United States fish and wildlife service exempt from game laws.

70-4-122. Coon dog training.

70-4-123. Hunting with bow and arrow while in possession of firearms or accompanied by a person in possession of firearms-Penalty.

70-4-124. Wearing daylight fluorescent orange color while hunting big game required-Penalty.

70-4-125. Causing death to wildlife, hunting dog or domestic animal by poisonous substance prohibited.

70-4-126. Use of electronic or battery operated device to lure or kill a fox prohibited-Penalty.

70-4-127. Dove-baiting prohibited.

70-4-128. Posting notice of dove-baiting.

70-4-129. Sale of fish and wildlife by charitable organizations.

70-4-130. Albino deer.

Part 2-Wildlife Regulation and Protection.

70-4-201. Possession of or traffic in protected wildlife illegal-Exception-Penalty.

70-4-202. Use or possession of wildlife, hides or parts thereof illegally taken unlawful.

70-4-203. Transportation of protected game or fish out of the state-Duty of transporters-Penalty.

70-4-204. Cold storage of wildlife-Penalty for violations.

70-4-205. Use of state-controlled water areas and land bordering thereon.

70-4-206. Pollution of waters-Penalty for violations-Nuisance.

70-4-207. Defacing and destroying notice of commission or agency-Penalty.

70-4-208. Unlawful importation of skunks-Penalty.

70-4-209. Purchase or sale of red fox hides, furs or pelts.

70-4-210. Deer hides-Squirrel pelts and tails.

70-4-211. Nets and other fishing equipment near mouth of watercourse-Penalty. 
Chapter 8, "Species Protection and Conservation”

Part 1-Nongame and Endangered Species.

70-8-101. Short title.

70-8-102. Declaration of policy.

70-8-103. Part definitions.

70-8-104. Nongame species-Promulgation of regulations-Prohibited acts.

70-8-105. Endangered or threatened species list.

70-8-106. Management programs-Exceptions to regulations.

70-8-107. Rulemaking authority.

70-8-108. Penalties for violations-Searches and seizures-Forfeitures.

70-8-109. Construction of provisions-Importation from other states.

70-8-110. Funding-Donations.

70-8-111. Authorization to enter agreements.

70-8-112. Species similar to endangered species.

Part 3-Rare Plant Protection and Conservation.

70-8-301. Short title.

70-8-302. Legislative findings.

70-8-303. Part definitions.

70-8-304. Powers of commissioner.

70-8-305. List of endangered species.

70-8-306. Licensing and regulation of nursery farmers.

70-8-307. Right of access for inspections.

70-8-308. Public works projects.

70-8-309. Violations.

70-8-310. Penalties.

70-8-311. Enforcement of provisions-Injunctions. 
70-8-312. Powers of commissioner.

70-8-313. Rules and regulations.

70-8-314. Limitations on implementing provisions. 
APPENDIX D

\section{WILDLIFE HABITATS ON THE OAK RIDGE RESERVATION}



The diverse vegetation communities on the Oak Ridge Reservation (ORR) create favorable habitats for a wide variety of wildlife species typical of eastern Tennessee. The nature of the habitat of an area greatly influences the wildlife species that can occupy it. Small mammals such as mice or rats can be limited to a single habitat type, while the larger mammals such as fox or deer can range over and be dependent on several habitats. As a result, the boundaries of animal communities are not as clearly demarcated as those of plants. Most of the birds and mammals found on the ORR can tolerate and adapt to a variety of habitats and, therefore, can be found in habitats other than those considered typical for the respective species (DOE 1980).

Species lists for the ORR vertebrates (i.e., amphibians, reptiles, birds, and mammals) are provided in Appendix E. These lists represent a compilation of information from a variety of sources such as Kitchings and Mann 1976; Johnson 1964; Dahlman, Kitchings, and Elwood 1977; Ryon and Loar 1988; Klein 1989; and Mitchell et al. 1996. Yearly Partners in Flight surveys also contribute information regarding bird populations on the ORR. Of the biota, only vertebrates have been included; however, information is available from various sources on the terrestrial and aquatic invertebrate population (Kitchings and Mann 1976; Loar, Solomon, and Cada 1981; Loar et al. 1981; Loar et al. 1985; Loar, Boston, and Bailey 1987; Loar et al. 1989; Loar et al. 1991; Loar et al. 1992a; Loar et al. 1992b; Loar 1992; Morton 1962). Additional information on the rare fauna on the ORR is found in the Resource Management Plan for Threatened and Endangered Animal Species (Kroodsma 1987).

Information on the small mammals of the ORR has been obtained by studies of populations in varied habitats and through collections for laboratory experiments. Data for the large mammals have been accrued by sighting, trapping, roadkills, track studies, radio-collar studies, and deer hunts. Information on birds has been acquired mainly by field observations. Data for amphibians and reptiles were obtained by field studies and collections.

Most of the small mammals have home ranges of only a few acres, and some species are restricted to certain habitats. However, some species, such as the southeastern shrew (the smallest mammal on the ORR), occur in practically every habitat. At least eight species of bats also feed on insects over several habitats. During the day the bats roost in caves, hollow trees, under leaves, and in varied habitats. Larger mammals such as raccoon, red and gray foxes, coyote, bobcat, and white-tailed deer travel for miles through most habitats.

In the grassland/forb stage of vegetation succession, the principal species of small mammals are the southeastern shrew, least shrew, short-tailed shrew, eastern harvest mouse, hispid cotton rat, pine mouse, and eastern cottontail rabbit. The eastern mole occurs in areas of loose soil. Closely mowed or grazed areas and dense kudzu growths near soil surfaces are preferred by the woodchuck. Otherwise, the closely mowed or grazed areas are virtual deserts for mammals except for cottontails, striped skunks, coyotes, red foxes, and deer, which feed there, especially at night. As vegetation succession proceeds into brush, small trees, and vines, the white-footed mouse occurs. The golden mouse is found in sites with heavy vine growth (e.g., Japanese honeysuckle) and in dense thickets of cane. The opossum becomes a more common resident with the influx of brush and trees. Large mammals can range through both early and late stages of this habitat. The coyote, in particular, seems to prefer grassy and shrubby areas. Brush, small trees, and vines are heavily browsed by deer. Bird species found in this habitat include northern bobwhite, red-tailed hawk, field sparrow, eastern towhee, blue grosbeak, eastern meadowlark, and red-winged blackbird. The eastern bluebird population has increased with the placement of nesting boxes. Canada geese are prevalent in areas that contain mowed turf grass. Numerous frog, toad, lizard, and snake species are found in the old field areas.

Hardwood and mixed hardwood/conifer habitats occur as the trees begin to mature and canopies begin to close. Eastern gray and southern flying squirrels become inhabitants. The southeastern shrew, eastern mole, short-tailed shrew, white-footed mouse, and eastern chipmunk continue to live in such areas. Among the predators, mink and bobcat, in particular, become more numerous. White-tailed deer mainly utilize the mature forests for mast, cover and protection against weather extremes. The hardwood and mixed forests provide habitat for a large number of bird species, including the northern flicker, redbellied woodpecker, hairy woodpecker, downy woodpecker, blue jay, Kentucky warbler, ovenbird, Carolina chickadee, tufted titmouse, Acadian flycatcher, and scarlet tanager. A large number of raptorial 
birds use the woodlands on the ORR for nesting and hunting. The red-tailed, red-shouldered, and broadwinged hawks are common throughout the area. Wild turkeys have been reintroduced into the area and use these habitats. Amphibians and reptiles found in these habitats include the dusky salamander, American toad, eastern box turtle, ground skink, worm snake, black racer, black rat snake, black kingsnake, eastern milk snake, and northern copperhead.

Field/forest-edge habitat on the Reservation supports a variety of wildlife species. Mammals that commonly use edge areas on the ORR include white-tailed deer, coyote, red fox, gray fox, raccoon, skunk, and opossum. Bird species that use edge areas include yellow-breasted chat, yellow warbler, common yellowthroat, northern cardinal, eastern towhee, brown thrasher, Carolina wren, song sparrow, and indigo bunting.

Pine plantations, which grow rapidly in comparison to the hardwoods, form a dense canopy that shades out most undergrowth. Such areas become essentially barren of both small and large wildlife species except around the edges, where sunlight can penetrate and the lower-growing plants and ascending vines provide suitable habitat for some species. Some large mammals might use the stands for protection. When the trees are thinned and fewer, but larger trees are present, the canopies open, undergrowth appears, and small mammals such as those characteristic of early- to mid-stage hardwoodmixed hardwood/conifer forests occur. Compared to other habitat types, bird species have a low preference for pure pine areas bordering the transmission-line corridors. The pine warbler and the whitethroated sparrow can be found in these areas, but few other species frequent this habitat. In surveys comparing avian species, there was significantly lower diversity in pine plantations than in hardwood forests (Hardy 1991). The dense pine plantations on the ORR are little used as habitat by reptiles or amphibians (Johnson 1964). Older, more open pine forests with well-developed understories can support a fairly high diversity of wildlife species, however.

Many reptiles and amphibians occur in the various aquatic and wetland areas, including turtles (e.g., painted turtle, red-eared slider, Cumberland slider, snapping turtle, stinkpot, musk turtle), snakes (e.g., northern watersnake, queen snake), salamanders (e.g., four-toed, marbled, spotted, tiger, spring, slimy, dusky, red, two-lined, red-spotted newt), and frogs (e.g., bullfrog, green, southern leopard, chorus, spring peeper, gray treefrog, American toad, eastern spadefoot toad, eastern narrow mouth toad). Muskrat and beaver are bound closely to aquatic habitats and seldom travel far from the protection of bodies of water. The muskrat prefers open areas with aquatic vegetation and dense growths of riparian grasses, sedges, and rushes. Beaver rely heavily on trees for food, dams, and lodges. Rice rats seldom occur in dense growths of sedges, cattails, rushes, and grasses in and around streams, ponds and lakes. Mink frequent aquatic habitats, but also hunt in surrounding fields and forests. Raccoons are common in aquatic habitats, but also range into other environments. Depending on habitat (old field, forest, etc.), various species frequent the water's edge. Many mammals come frequently to this habitat to drink. The bald eagle occurs occasionally as a transient and wintering bird and could potentially nest near the ORR. Osprey nesting platforms have been successful on the ORR and other parts of Watts Bar Lake. The Canada goose has become well established, and population-control measures are being taken in an attempt to decrease the numbers. Great blue herons and green herons nest on the ORR and frequent streams, rivers, and lakes in the area. Marsh birds are not common on the ORR because their habitat is very limited in acreage.

Caves are common in the limestone of east Tennessee, and there are several on the ORR. Several species of bats are the only mammals to live (roosting or hibernating) deep in the caves. Other species of bats (e.g., red) occasionally roost in the light zones near the mouths of caves. A few species of small mammals (e.g., white-footed mouse, short tailed shrew, mink) can include cave openings in their range. Tracks of raccoon, bobcat, mink, and foxes can be seen in wet soil inside cave mouths. Mist-net surveys at cave entrances on the ORR confirmed bat activity in these areas, including the presence of the federally endangered gray bat. Many species of amphibians (e.g., green salamander) also occur in ORR caves. Vultures also nest in cave entrances.

Woodchucks frequently burrow under buildings surrounded by lawn or pastures. A few species of bats "hang up" during the day in buildings. The striped skunk, bobcat, opossum, raccoon, foxes, and gray and flying squirrels often den in or under isolated, abandoned buildings. House sparrows, starlings, and rock pigeons are often found in buildings. Barn owls can roost and nest in buildings, particularly 
abandoned barns. Other birds, such as wrens, woodpeckers, swallows, eastern phoebes, eastern bluebirds, tufted titmice, Carolina chickadees, and vultures, can nest in abandoned buildings.

\section{REFERENCES}

Dahlman, R. C., J. T. Kitchings, and J. W. Elwood. 1977. Land and Water Resources for Environmental Research on the Oak Ridge Reservation. ORNL/TM-5352, Oak Ridge National Laboratory, Oak Ridge, TN.

DOE (Department of Energy). 1980. Oak Ridge Reservation Land Use Plan. DOE/ORO-748 (Rev. 1), Technical Information Center, Oak Ridge, TN.

Hardy C. 1991. “A Comparison of Bird Communities in Loblolly vs. White Pine Plantations on the Oak Ridge National Environmental Research Park.” Thesis, University of Tennessee, Knoxville.

Johnson, R. M. 1964. The Herpatofauna of the Oak Ridge Area. ORNL-3653, Oak Ridge National Laboratory, Oak Ridge, TN.

Kitchings J. T., and L. K. Mann. 1976. A Description of the Terrestrial Ecology of the Oak Ridge Environmental Research Park. ORNL/TM-5073, Oak Ridge National Laboratory, Oak Ridge, TN.

Klein, J. A. 1989. "A checklist of the reptiles and amphibians on the Department of Energy Oak Ridge Reservation, Anderson and Roane Counties, Tennessee.” Journal of the Tennessee Academy of Science 64:228-230.

Kroodsma, R. L. 1987. Resource Management Plan for the Oak Ridge Reservation, Volume 24: Threatened and Endangered Animal Species. ORNL/ESH-1, Oak Ridge National Laboratory, Oak Ridge, TN.

Loar, J. M., J. A. Solomon, and G. F. Cada. 1981. Technical Background Information for the ORNL Environmental and Safety Report, Volume 2: A Description of the Aquatic Ecology of White Oak Creek Watershed and the Clinch River Below Melton Hill Dam. ORNL/TM-7509/V2, Oak Ridge National Laboratory, Oak Ridge, TN.

Loar, J. M., F. A. Burkhart, G. F. Cada, J. W. Huckabee, J. T. Kitchings, K. D. Kumar, A. M. Sasson, J. A. Solomon, and J. D. Story. 1981. Ecological Studies in the Vicinity of the Oak Ridge Gaseous Diffusion Plant. ORNL/TM-6714, Oak Ridge National Laboratory, Oak Ridge, TN.

Loar, J. M., J. M. Giddings, G. F. Cada, J. A. Solomon, G. R. Southworth, and A. J. Gatz. 1985. "Ecological Characterization of Bear Creek Watershed." In Appendices: Remedial Alternatives for Bear Creek Valley Waste Disposal Area, A-1-A-122. Y/TS-109, Oak Ridge Y-12 Plant, Oak Ridge, TN.

Loar, J. M., H. L. Boston, and R. D. Bailey. 1987. “Description of White Oak Creek Watershed.” In First Annual Report on the ORNL Biological Monitoring and Abatement Program, 3-33. Draft Report, Oak Ridge National Laboratory, Oak Ridge, TN. 
Loar, J. M., J. M. Giddings, S. M. Adams, J. F. McCarthy, and G. R. Southworth. 1989. Biological Monitoring and Abatement Program for East Fork Poplar Creek. ORNL/TM-10265, Oak Ridge National Laboratory, Oak Ridge, TN.

Loar, J. M. S. M. Adams, L. J. Allison, B. G. Blaylock, H. L. Boston, M. A. Huston, B. L. Kimmel, J. T. Kitchings, C. R. Olson, J. G. Smith, G. R. Southworth, A. J. Stewart, and B. T. Walton. 1991. Oak Ridge National Laboratory Biological Monitoring and Abatement Program for White Oak Creek Watershed and the Clinch River. ORNL/TM-10370, Oak Ridge National Laboratory, Oak Ridge, TN.

Loar, J. M. (ed). 1992. First Annual Report on the Y-12 Plant Biological Monitoring and Abatement Program. Y/TS-866, Oak Ridge National Laboratory, Oak Ridge, TN.

Loar, J. M. S. M. Adams, B. G. Blaylock, H. L. Boston, M. A Huston, B. L. Kimmel, J. T. Kitchings, C. R. Olson, M. G. Ryon, J. G. Smith, G. R. Southworth, A. J. Stewart, B. T. Walton, H. Amano, C. T. Garten, and L. J. Meyers. 1992a. First Annual Report on the ORNL Biological Monitoring and Abatement Program. ORNL/TM-10399, Oak Ridge National Laboratory, Oak Ridge, TN.

Loar, J. M., L. A. Kszos, S. M. Adams, M. G. Ryon, J. G. Smith, G. R. Southworth and A. J. Stewart. 1992b. Oak Ridge Gaseous Diffusion Plant Biological Monitoring and Abatement Program for Mitchell Branch. ORNL/TM-11965, Oak Ridge National Laboratory, Oak Ridge, TN.

Mitchell, J. M., E. R. Vail, J. W. Webb, J. W. Evans, A. L. King, and P. A. Hamlet. 1996. Survey of Protected Terrestrial Vertebrates on the Oak Ridge Reservation. ES/ER/TM-188/RI, Oak Ridge National Laboratory, Oak Ridge, TN.

Morton, R. J. 1962. Status Report No. 3 on Clinch River Study. ORNL-3370, Oak Ridge National Laboratory, Oak Ridge, TN.

Ryon, M. G., and J. M. Loar. 1988. "A checklist of fishes on the Department of Energy Oak Ridge Reservation.” Journal of the Tennessee Academy of Science 63(4): 97-102. 
APPENDIX E

VERTEBRATE WILDLIFE SPECIES OF THE OAK RIDGE RESERVATION 

Amphibians and Reptiles of the Oak Ridge Reservation ${ }^{a, b}$

\begin{tabular}{|c|c|c|}
\hline Family & Scientific Name & Common Name ${ }^{c}$ \\
\hline \multicolumn{3}{|c|}{ Amphibians-Order: Caudata } \\
\hline \multirow[t]{3}{*}{ Ambystomatidae } & Ambystoma maculatum & Spotted salamander \\
\hline & Ambystoma opacum & Marbled salamander \\
\hline & Ambystoma tigrinum tigrinum & Eastern tiger salamander \\
\hline Cryptobranchidae & Cryptobranchus alleganiensis & Hellbender \\
\hline \multirow[t]{11}{*}{ Plethodontidae } & Aneides aeneus & Green salamander \\
\hline & Desmognathus fuscus & $\begin{array}{l}\text { Dusky salamander, northern dusky } \\
\text { salamander }\end{array}$ \\
\hline & Eurycea cirrigera & Southern two-lined salamander \\
\hline & Eurycea longicauda & Long-tailed salamander \\
\hline & Eurycea lucifuga & Cave salamander \\
\hline & Gyrinophilus porphyriticus & Spring salamander \\
\hline & Hemidactylium scutatum & Four-toed salamander ${ }^{d}$ \\
\hline & Plethodon cinereus & $\begin{array}{l}\text { Eastern red-backed salamander, } \\
\text { red-backed salamander, redback } \\
\text { salamander }\end{array}$ \\
\hline & Plethodon glutinosus & $\begin{array}{l}\text { Northern slimy salamander, slimy } \\
\text { salamander }\end{array}$ \\
\hline & Pseudotriton montanus & Mud salamander \\
\hline & Pseudotriton ruber ruber & Northern red salamander \\
\hline Salamandridae & Notophthalmus viridescens & Eastern newt (red-spotted newt) \\
\hline \multicolumn{3}{|c|}{ Amphibians-Order: Anura } \\
\hline \multirow[t]{2}{*}{ Bufonidae } & Bufo americanus americanus & Eastern American toad \\
\hline & Bufo fowleri & Fowler’s toad \\
\hline \multirow[t]{4}{*}{ Hylidae } & Acris crepitans crepitans & $\begin{array}{l}\text { Eastern cricket frog, northern cricket } \\
\text { frog }\end{array}$ \\
\hline & Hyla versicolor & Gray treefrog \\
\hline & Pseudacris crucifer crucifer & Northern spring peeper \\
\hline & Pseudacris feriarum feriarum & Upland chorus frog \\
\hline Microhylidae & Gastrophryne carolinensis & Eastern narrow-mouthed toad \\
\hline \multirow[t]{5}{*}{ Ranidae } & Rana catesbeiana & American bullfrog, bullfrog \\
\hline & Rana clamitans melanota & Green frog, northern green frog \\
\hline & Rana palustris & Pickerel frog \\
\hline & Rana sphenocephala & Southern leopard frog \\
\hline & Rana sylvatica & Wood frog \\
\hline Scaphiopodidae & Scaphiopus holbrookii & Eastern spadefoot \\
\hline
\end{tabular}

Reptiles-Order: Testudines

\begin{tabular}{lll}
\hline Chelydridae & Chelydra serpentina serpentina & Common snapping turtle \\
Emydidae & Chrysemys picta & Painted turtle \\
& Graptemys geographica & Common map turtle \\
& Graptemys ouachitensis & Ouachita map turtle \\
& Graptemys pseudogeographica & False map turtle \\
& Pseudemys concinna concinna & Eastern river cooter \\
& Terrapene carolina carolina & Eastern box turtle \\
& Trachemys scripta elegans & Red-eared slider \\
& Trachemys scripta troostii & Cumberland slider \\
Kinosternidae & Sternotherus minor & Loggerhead musk turtle
\end{tabular}


Amphibians and Reptiles of the Oak Ridge Reservation ${ }^{a, b}$ (continued)

\begin{tabular}{|c|c|c|}
\hline Family & Scientific Name & Common Name $^{c}$ \\
\hline \multicolumn{3}{|c|}{ Reptiles-Order: Testudines (continued) } \\
\hline & Sternotherus odoratus & Common musk turtle (stinkpot) \\
\hline Trionychidae & Apalone spinifera spinifera & Eastern spiny softshell turtle \\
\hline \multicolumn{3}{|c|}{ Reptiles-Order: Squamata } \\
\hline \multicolumn{3}{|c|}{ Suborder: Serpentes } \\
\hline \multirow[t]{17}{*}{ Colubridae } & Carphophis amoenus amoenus & Eastern worm snake \\
\hline & Cemophora coccinea & Scarlet snake \\
\hline & Coluber constrictor & Racer (black racer) \\
\hline & Diadophis punctatus edwardsii & Northern ringneck snake \\
\hline & Elaphe guttata guttata & Corn snake \\
\hline & Elaphe obsoleta & Rat snake \\
\hline & Heterodon platirhinos & Eastern hog-nosed snake \\
\hline & $\begin{array}{l}\text { Lampropeltis calligaster } \\
\text { rhombomaculata }\end{array}$ & Mole kingsnake \\
\hline & Lampropeltis getula nigra & Black kingsnake \\
\hline & Lampropeltis triangulum triangulum & Eastern milk snake \\
\hline & Nerodia sipedon & Northern water snake \\
\hline & Opheodrys aestivus & Rough green snake, rough greensnake \\
\hline & Regina septemvittata & Queen snake, queensnake \\
\hline & Storeria dekayi & $\begin{array}{l}\text { Brown snake, Dekay's brown snake, } \\
\text { Dekay's brownsnake }\end{array}$ \\
\hline & $\begin{array}{l}\text { Storeria occipitomaculata } \\
\text { occipitomaculata }\end{array}$ & Northern redbelly snake \\
\hline & Thamnophis sirtalis sirtalis & $\begin{array}{l}\text { Common garter snake (eastern garter } \\
\text { snake) }\end{array}$ \\
\hline & Virginia valeriae valeriae & Eastern earth snake \\
\hline Viperidae & Agkistrodon contortrix mokasen & Northern copperhead \\
\hline \multicolumn{3}{|l|}{ Suborder: Iguania } \\
\hline Phrynosomatidae & Sceloporus undulatus hyacinthinus & Northern fence lizard \\
\hline \multicolumn{3}{|c|}{ Suborder: Autarchoglossa } \\
\hline \multirow[t]{3}{*}{ Scincidae } & Eumeces fasciatus & Five-lined skink \\
\hline & Eumeces laticeps & Broad-headed skink \\
\hline & Scincella lateralis & Ground skink, little brown skink \\
\hline Teiidae & Cnemidophorus sexlineatus & Six-lined racerunner \\
\hline
\end{tabular}

${ }^{a}$ Updated February 2007.

${ }^{b}$ Taxonomic source: Integrated Taxonomic Information System (ITIS), http://www.itis.gov.

${ }^{c}$ Common names in parentheses are used locally but are not listed in ITIS.

${ }^{d}$ Deemed by state as in need of management. 


\section{Mammals of the Oak Ridge Reservation}

\begin{tabular}{|c|c|}
\hline Common name & Scientific name \\
\hline Opossum & Didelphis virginiana \\
\hline Southeastern shrew ${ }^{a}$ & Sorex longirostris \\
\hline Shorttailed shrew & Blarina brevicauda \\
\hline Least shrew & Cryptotis parva \\
\hline Eastern mole & Scalopus aquaticus \\
\hline Gray bat $^{b}$ & Myotis grisescens \\
\hline Eastern pipistrelle & Pipistrellus subflavus \\
\hline Silver-haired bat & Lasionycteris noctivagans \\
\hline Big brown bat & Eptesicus fuscus \\
\hline Eastern red bat & Lasiurus borealis \\
\hline Evening bat & Nycticeius humeralis \\
\hline Little brown bat & Myotis lucifugus \\
\hline Seminole bat & Lasiurus seminolus \\
\hline Eastern cottontail & Sylvilagus floridanus \\
\hline Eastern chipmunk & Tamias striatus \\
\hline Woodchuck (groundhog) & Marmota monax \\
\hline Eastern gray squirrel & Sciurus carolinensis \\
\hline Southern flying squirrel & Glaucomys volans \\
\hline Beaver & Castor canadensis \\
\hline Eastern harvest mouse & Reithrodontomys humulis \\
\hline White-footed mouse & Peromyscus leucopus \\
\hline Golden mouse & Peromyscus nuttalli \\
\hline Deer mouse & Peromyscus maniculatus \\
\hline Hispid cotton rat & Sigmodon hispidus \\
\hline Pine vole & Pitymys pinetorum \\
\hline Meadow vole & Microtus pennsylvanicus \\
\hline Muskrat & Ondatra zibethica \\
\hline Norway rat & Rattus norvegicus \\
\hline House mouse & Mus musculus \\
\hline Coyote & Canis latrans \\
\hline Red fox & Vulpes vulpes \\
\hline Gray fox & Urocyon cinereoargenteus \\
\hline Raccoon & Procyon lotor \\
\hline Mink & Mustela vison \\
\hline Striped skunk & Mephitis mephitis \\
\hline White-tailed deer & Odocoileus virginianus \\
\hline Elk & Cervus canadensis \\
\hline Bobcat & Lynx rufus \\
\hline
\end{tabular}

${ }^{a}$ Deemed by state as in need of management.

${ }^{b}$ Federally endangered. 
Birds of the Oak Ridge Reservation

\begin{tabular}{|c|c|c|c|}
\hline Species & Scientific name & Presence & Status \\
\hline \multicolumn{4}{|c|}{ Loons } \\
\hline Common loon & Gavia immer & Winter & \\
\hline \multicolumn{4}{|c|}{ Grebes } \\
\hline Pied-billed grebe & Podilymbus podiceps & Casual visitor & \\
\hline Horned grebe & Podiceps auritus & Winter & \\
\hline Eared grebe & Podiceps nigricollis & Transient & \\
\hline \multicolumn{4}{|c|}{ Cormorants } \\
\hline Double-crested cormorant & Phalacrocorax auritus & Casual visitor & \\
\hline \multicolumn{4}{|c|}{ Darters } \\
\hline Anhinga & Anhinga anhinga & Transient & NM \\
\hline \multicolumn{4}{|c|}{ Bitterns and herons } \\
\hline Great blue heron & Ardea herodias & Breeder & \\
\hline Great egret & Ardea alba & Casual visitor & NM \\
\hline Snowy egret & Egretta thula & Migrant & NM \\
\hline Little blue heron & Egretta caerulea & Casual visitor & NM \\
\hline Green heron & Butorides virescens & Breeder & \\
\hline Black-crowned night-heron & Nycticorax nycticorax & Breeder & \\
\hline \multicolumn{4}{|c|}{ Swans, geese, and ducks } \\
\hline Mute swan & Cygnus olor & Casual visitor & \\
\hline Canada goose & Anser canadensis & Breeder & \\
\hline Ross’ goose & Chen rossii & Migrant & \\
\hline Snow goose & Chen caerulescens & Migrant & \\
\hline Greater white-fronted goose & Anser albifrons & Migrant & \\
\hline Wood duck & Aix sponsa & Breeder & \\
\hline Green-winged teal & Anas crecca & Winter & \\
\hline American black duck & Anas rubripes & Winter & \\
\hline Mallard & Anas platyrhynchos & Breeder & \\
\hline Northern pintail & Anas acuta & Winter & \\
\hline Blue-winged teal & Anas discors & Winter & \\
\hline Gadwall & Anas strepera & Winter & \\
\hline American wigeon & Anas americana & Winter & \\
\hline Northern shoveler & Anas clypeata & Winter & \\
\hline Canvasback & Aythya valisineria & Winter & \\
\hline Ring-necked duck & Aythya collaris & Winter & \\
\hline Greater scaup & Aythya marila & Winter & \\
\hline Lesser scaup & Aythya affinis & Winter & \\
\hline Bufflehead & Bucephala clangula & Winter & \\
\hline Hooded merganser & Lophodytes cucullatus & Winter & \\
\hline Red-breasted merganser & Mergus serrator & Winter & \\
\hline Common merganser & Mergus merganser & Winter & \\
\hline Ruddy duck & Oxyura jamaicensus & Winter & \\
\hline \multicolumn{4}{|c|}{ Vultures } \\
\hline Black vulture & Coragyps atratus & Breeder & \\
\hline Turkey vulture & Cathartes aura & Breeder & \\
\hline
\end{tabular}


Birds of the Oak Ridge Reservation (continued)

\begin{tabular}{|c|c|c|c|}
\hline Species & Scientific name & Presence & Status \\
\hline \multicolumn{4}{|c|}{ Kites, hawks, eagles, and allies } \\
\hline Osprey & Pandion haliaetus & Breeder & \\
\hline Bald eagle & Haliaeetus leucocephalus & Casual visitor & NM \\
\hline Northern harrier & Circus cyaneus & Winter & NM \\
\hline Sharp-shinned hawk & Accipiter striatus & Possible breeder & NM \\
\hline Cooper's hawk & Accipiter cooperii & Possible breeder & \\
\hline Red-shouldered hawk & Buteo lineatus & Breeder & \\
\hline Red-tailed hawk & Buteo jamaicensis & Breeder & \\
\hline Broad-winged hawk & Buteo platypterus & Breeder & \\
\hline \multicolumn{4}{|c|}{ Falcons } \\
\hline American kestrel & Falco sparverius & Breeder & \\
\hline Peregrine falcon & Falco peregrinus & Migrant & SE \\
\hline \multicolumn{4}{|c|}{ Grouse, turkey, and quail } \\
\hline Ruffed grouse & Bonasa umbellus & Casual visitor & \\
\hline Wild turkey & Meleagris gallopavo & Breeder & \\
\hline Northern bobwhite & Colinus virginianus & Breeder & \\
\hline \multicolumn{4}{|c|}{ Rails and coots } \\
\hline Sora & Porzana carolina & Migrant & \\
\hline American coot & Fulica americana & Casual visitor & \\
\hline \multicolumn{4}{|c|}{ Cranes } \\
\hline Sandhill crane & Grus canadensis & Migrant & \\
\hline \multicolumn{4}{|c|}{ Plovers } \\
\hline Killdeer & Charadrius vociferus & Breeder & \\
\hline Semipalmated plover & Charadrius semipalmatus & Migrant & \\
\hline \multicolumn{4}{|c|}{ Sandpipers and allies } \\
\hline Greater yellowlegs & Tringa melanoleuca & Migrant & \\
\hline Lesser yellowlegs & Tringa flavipes & Migrant & \\
\hline Solitary sandpiper & Tringa solitaria & Migrant & \\
\hline Spotted sandpiper & Actitus macularius & Casual visitor & \\
\hline Pectoral sandpiper & Calidris melanotos & Migrant & \\
\hline White-rumped sandpiper & Calidris fuscicollis & Migrant & \\
\hline Least sandpiper & Calidris minutilla & Migrant & \\
\hline Common snipe & Gallinago gallinago & Winter & \\
\hline American woodcock & Scolopax minor & Breeder & \\
\hline \multicolumn{4}{|c|}{ Gulls and terns } \\
\hline Bonaparte’s gull & Larus Philadelphia & Winter & \\
\hline Ring-billed gull & Larus delawarensis & Winter & \\
\hline Caspian tern & Sterna caspia & Transient & \\
\hline Forster's tern & Sterna forsteri & Transient & \\
\hline \multicolumn{4}{|c|}{ Pigeons and doves } \\
\hline Rock pigeon & Columba livia & Breeder & \\
\hline Mourning dove & Zenaida macroura & Breeder & \\
\hline \multicolumn{4}{|c|}{ Cuckoos } \\
\hline Yellow-billed cuckoo & Coccyzus americanus & Breeder & \\
\hline
\end{tabular}


Birds of the Oak Ridge Reservation (continued)

\begin{tabular}{|c|c|c|c|}
\hline Species & Scientific name & Presence & Status \\
\hline \multicolumn{4}{|c|}{ Owls } \\
\hline Northern saw-whet owl & Aegolius acadicus & Transient & \\
\hline Eastern screech-owl & Megascops asio & Breeder & \\
\hline Great horned owl & Bubo virginianus & Breeder & \\
\hline Barred owl & Strix varia & Breeder & \\
\hline Barn owl & Tyto alba & Possible breeder & NM \\
\hline \multicolumn{4}{|c|}{ Goatsuckers } \\
\hline Common nighthawk & Chordeiles minor & Breeder & \\
\hline Chuck-will's-widow & Caprimulgus carolinensis & Breeder & $\mathrm{C}$ \\
\hline Whip-poor-will & Caprimulgus vociferus & Breeder & \\
\hline \multicolumn{4}{|c|}{ Swifts } \\
\hline Chimney swift & Chaetura pelagica & Breeder & \\
\hline \multicolumn{4}{|c|}{ Hummingbirds } \\
\hline Ruby-throated hummingbird & Archilochus colubris & Breeder & \\
\hline \multicolumn{4}{|c|}{ Kingfishers } \\
\hline Belted kingfisher & Ceryle alcyon & Breeder & \\
\hline \multicolumn{4}{|c|}{ Woodpeckers } \\
\hline Red-bellied woodpecker & Melanerpes carolinus & Breeder & \\
\hline Red-headed woodpecker & Melanerpes erythrocephalus & Breeder & \\
\hline Yellow-bellied sapsucker & Sphyrapicus varius & Winter & NM \\
\hline Downy woodpecker & Picoides pubescens & Breeder & \\
\hline Hairy woodpecker & Picoides vollosus & Breeder & \\
\hline Northern flicker & Colaptes auratus & Breeder & \\
\hline Pileated woodpecker & Dryocopus pileatus & Breeder & \\
\hline \multicolumn{4}{|c|}{ Tyrant Flycatchers } \\
\hline Olive-sided flycatcher & Contopus cooperi & Migrant & NM \\
\hline Eastern wood-pewee & Contopus virens & Breeder & \\
\hline Acadian flycatcher & Empidonax virescens & Breeder & \\
\hline Willow flycatcher & Empidonax trailii & Breeder & \\
\hline Eastern phoebe & Sayornis phoebe & Breeder & \\
\hline Great crested flycatcher & Myiarchus crinitus & Breeder & \\
\hline Eastern kingbird & Tyrannus tyrannus & Breeder & \\
\hline Western kingbird & Tyrannus verticalis & Transient & \\
\hline \multicolumn{4}{|c|}{ Larks } \\
\hline Horned lark & Eremophila alpestris & Casual visitor & \\
\hline \multicolumn{4}{|c|}{ Swallows } \\
\hline Purple martin & Progne subis & Breeder & \\
\hline Tree swallow & Tachycineta bicolor & Breeder & \\
\hline Northern rough-winged swallow & Stelgidopteryx serripennis & Breeder & \\
\hline Cliff swallow & Petrochelidon fulva & Breeder & \\
\hline Barn swallow & Hirundo rustica & Breeder & \\
\hline Bank swallow & Petrochelidon pyrrhonota & Migrant & \\
\hline
\end{tabular}


Birds of the Oak Ridge Reservation (continued)

\begin{tabular}{|c|c|c|c|}
\hline Species & Scientific name & Presence & Status \\
\hline \multicolumn{4}{|c|}{ Jays and crows } \\
\hline Blue jay & Cyannocitta cristata & Breeder & \\
\hline American crow & Corvus brachyrhynchos & Breeder & \\
\hline \multicolumn{4}{|c|}{ Titmice and chickadees } \\
\hline Carolina chickadee & Poecile carolinensis & Breeder & \\
\hline Tufted titmouse & Baeolophus bicolor & Breeder & \\
\hline \multicolumn{4}{|c|}{ Nuthatches } \\
\hline Red-breasted nuthatch & Sitta canadensis & Winter & \\
\hline White-breasted nuthatch & Sitta carolinensis & Breeder & \\
\hline Brown-headed nuthatch & Sitta pusilla & Breeder & $\mathrm{C}$ \\
\hline \multicolumn{4}{|c|}{ Creepers } \\
\hline Brown creeper & Certhia americana & Winter & \\
\hline \multicolumn{4}{|c|}{ Wrens } \\
\hline Carolina wren & Thryothorus ludovicianus & Breeder & \\
\hline House wren & Troglodytes aedon & Breeder & \\
\hline Winter wren & Troglodytes troglodytes & Winter & \\
\hline Sedge wren & Cistothorus platensis & Migrant & \\
\hline Marsh wren & Cistothorus palustris & Migrant & \\
\hline \multicolumn{4}{|c|}{ Kinglets, gnatcatchers, and thrushes } \\
\hline Golden-crowned kinglet & Regulus satrapa & Winter & \\
\hline Ruby-crowned kinglet & Regulus calendula & Winter & \\
\hline Blue-gray gnatcatcher & Polioptila caerulea & Breeder & \\
\hline Eastern bluebird & Siala sialis & Breeder & \\
\hline Veery & Catharus fuscescens & Migrant & \\
\hline Swainson's thrush & Catharus ustulatus & Migrant & \\
\hline Hermit thrush & Catharus guttatus & Winter & \\
\hline Wood thrush & Hylocichla mustelina & Breeder & $\mathrm{C}$ \\
\hline American robin & Turdus migratorius & Breeder & \\
\hline Varied thrush & Ixoreus naevius & Transient & \\
\hline \multicolumn{4}{|c|}{ Pipits and wagtails } \\
\hline American pipit & Anthus rubescens & Migrant & \\
\hline \multicolumn{4}{|c|}{ Trashers and mockingbirds } \\
\hline Gray catbird & Dumetella carolinensis & Breeder & \\
\hline Northern mockingbird & Mimus polyglottos & Breeder & \\
\hline Brown thrasher & Toxostoma rufum & Breeder & \\
\hline \multicolumn{4}{|c|}{ Waxwings } \\
\hline Cedar waxwing & Bombycilla cedrorum & Breeder & \\
\hline \multicolumn{4}{|c|}{ Shrikes } \\
\hline Loggerhead shrike & Lanius ludovicianus & Transient & NM \\
\hline \multicolumn{4}{|c|}{ Starlings } \\
\hline European starling & Sturnus vulgaris & Breeder & \\
\hline
\end{tabular}


Birds of the Oak Ridge Reservation (continued)

\begin{tabular}{|c|c|c|c|}
\hline Species & Scientific name & Presence & Status \\
\hline \multicolumn{4}{|c|}{ Vireos } \\
\hline White-eyed vireo & Vireo griseus & Breeder & \\
\hline Blue-headed vireo & Vireo solitarius & Migrant & \\
\hline Yellow-throated vireo & Vireo flavifrons & Breeder & \\
\hline Red-eyed vireo & Vireo olivaceus & Breeder & \\
\hline Warbling vireo & Vireo gilvus & Casual visitor & \\
\hline \multicolumn{4}{|c|}{ Wood warblers } \\
\hline Blue-winged warbler & Vermivora pinus & Breeder & $\mathrm{C}$ \\
\hline Golden-winged warbler & Vermivora chrysotera & Migrant & NM, C \\
\hline Tennessee warbler & Vermivora peregrina & Migrant & \\
\hline Nashville warbler & Vermivora ruficapilla & Migrant & \\
\hline Northern parula & Parula americana & Breeder & \\
\hline Yellow warbler & Dendroica petechia & Breeder & \\
\hline Chestnut-sided warbler & Dendroica pensylvanica & Migrant & \\
\hline Magnolia warbler & Dendroica magnolia & Migrant & \\
\hline Cape May warbler & Dendroica tigrina & Migrant & \\
\hline Black-throated blue warbler & Dendroica caerulescens & Migrant & $\mathrm{C}$ \\
\hline Yellow-rumped warbler & Dendroica coronata & Winter & \\
\hline Black-throated green warbler & Dendroica virens & Possible breeder & \\
\hline Blackburnian warbler & Dendroica fusca & Migrant & \\
\hline Yellow-throated warbler & Dendroica dominica & Breeder & \\
\hline Pine warbler & Dendroica pinus & Breeder & \\
\hline Prairie warbler & Dendroica discolor & Breeder & $\mathrm{C}$ \\
\hline Palm warbler & Dendroica palmarum & Migrant & \\
\hline Bay-breasted warbler & Dendroica castanea & Migrant & \\
\hline Blackpoll warbler & Dendroica striata & Migrant & \\
\hline Cerulean warbler & Dendroica cerulea & Possible breeder & NM, C \\
\hline Black-and-white warbler & Mniotilta varia & Possible breeder & \\
\hline American redstart & Setophaga ruticilla & Possible breeder & \\
\hline Prothonotary warbler & Protonotaria citrea & Breeder & $\mathrm{C}$ \\
\hline Worm-eating warbler & Helmitheros vermivorus & Breeder & $\mathrm{C}$ \\
\hline Ovenbird & Seiurus aurocapillus & Breeder & \\
\hline Northern waterthrush & Seiurus novaboracensus & Migrant & \\
\hline Louisiana waterthrush & Seiurus motacilla & Possible breeder & $\mathrm{C}$ \\
\hline Kentucky warbler & Oporornis formosus & Breeder & $\mathrm{C}$ \\
\hline Common yellowthroat & Geothlypis trichas & Breeder & \\
\hline Hooded warbler & Wilsonia citrina & Breeder & \\
\hline Wilson's warbler & Wilsonia pusilla & Migrant & \\
\hline Canada warbler & Wilsonia canadensis & Migrant & \\
\hline Yellow-breasted chat & Icteria virens & Breeder & \\
\hline \multicolumn{4}{|c|}{ Tanagers } \\
\hline Summer tanager & Piranga rubra & Breeder & \\
\hline Scarlet tanager & Piranga olivacea & Breeder & \\
\hline
\end{tabular}


Birds of the Oak Ridge Reservation (continued)

\begin{tabular}{|c|c|c|c|}
\hline Species & Scientific name & Presence & Status \\
\hline \multicolumn{4}{|c|}{ Cardinals, grosbeaks, and allies } \\
\hline Northern cardinal & Cardinalis cardinalis & Breeder & \\
\hline Rose-breasted grosbeak & Pheucticus ludovicianus & Migrant & \\
\hline Blue grosbeak & Passerina caerulea & Breeder & \\
\hline Indigo bunting & Passerina cyanea & Breeder & \\
\hline Dickcissel & Spiza americana & Casual visitor & \\
\hline \multicolumn{4}{|c|}{ Towhees, sparrows, and allies } \\
\hline Eastern towhee & Pipilo erythrophthalmus & Breeder & \\
\hline American tree sparrow & Spizella arborea & Winter & \\
\hline Chipping sparrow & Spizella passerina & Breeder & \\
\hline Field sparrow & Spizella pusilla & Breeder & $\mathrm{C}$ \\
\hline Savannah sparrow & Passerculus sandwichensis & Migrant+winter & \\
\hline Grasshopper sparrow & Ammodramus savannarum & Breeder & \\
\hline Fox sparrow & Passerella iliaca & Winter & \\
\hline Song sparrow & Melospiza melodia & Breeder & \\
\hline Swamp sparrow & Melospiza georgiana & Winter & \\
\hline White-throated sparrow & Zonotrichia albicollis & Winter & \\
\hline White-crowned sparrow & Zonotrichia leucophrys & Migrant & \\
\hline Vesper sparrow & Pooecetes gramineus & Migrant & NM \\
\hline Dark-eyed junco & Junco hyemalis & Winter & \\
\hline \multicolumn{4}{|c|}{ Blackbirds and allies } \\
\hline Bobolink & Dolichonyx oryzivorus & Migrant & \\
\hline Red-winged blackbird & Agelaius phoeniceus & Breeder & \\
\hline Eastern meadowlark & Sturnella magna & Breeder & \\
\hline Common grackle & Quiscalus quiscula & Breeder & \\
\hline Brown-headed cowbird & Molothrus ater & Breeder & \\
\hline Orchard oriole & Icterus spurius & Breeder & \\
\hline Baltimore oriole & Icterus galbula & Breeder & \\
\hline \multicolumn{4}{|c|}{ Finches } \\
\hline Purple finch & Carpodacus purpureus & Winter & \\
\hline House finch & Carpodacus mexicanus & Breeder & \\
\hline Pine siskin & Carduelis pinus & Migrant & \\
\hline American goldfinch & Carduelis tristis & Breeder & \\
\hline Evening grosbeak & Coccothraustes vespertinus & Migrant & \\
\hline \multicolumn{4}{|c|}{ Old world sparrows } \\
\hline House sparrow & Passer domesticus & Breeder & \\
\hline
\end{tabular}





\section{APPENDIX F}

\section{DEFINITION OF WILDLIFE MANAGEMENT}



The "Tennessee Nongame and Endangered or Threatened Wildlife Species Conservation Act of 1974” (Title 70, Wildlife Resources, Chapter 8, "Species Protection and Conservation, Part 1-Nongame and Endangered Species," Tennessee Code Annotated) defines "management” as meaning "the collection and application of biological information for the purposes of increasing the number of individuals within species and populations of wildlife up to the optimum carrying capacity of their habitat and maintaining such levels. The term includes the entire range of activities that constitute a modern scientific resource program including, but not limited to, research, census, law enforcement, habitat acquisition and improvement, and education. Also included within the term, when and where appropriate, is the periodic or total protection of species or populations as well as regulated taking.”

Historically, at least through the 1960s, wildlife management was production oriented. That is, land management was directed toward a goal of producing the highest yield of game species for recreational harvesting. In the southeastern United States, these species were usually northern bobwhite, wild turkey, and white-tailed deer. Wildlife management and research in the 1970s grew rapidly and diversified. The Endangered Species Act of 1973 was indicative of public concern and an appreciation for nongame animals in general, and as a result, most state wildlife agencies embarked on nongame research programs that supplemented more traditional efforts toward the maintenance and expansion of game species.

Songbird and small mammal species were studied in a variety of forest types, and the community became the unit of study, with diversity being the major indicator of habitat quality (Landers and Johnson 1980). Habitat analysis was conducted at all levels of resolution. Microscale habitat data were used to determine the physical characteristics of forests that influenced the structure of avian communities, and the same techniques were applied to small mammal communities.

Wildlife management in its present form ranges from single-species management to management of communities consisting of many species to management of ecoregions, each consisting of many different communities distributed over a region. In state wildlife agencies, there is a trend to expend more effort on nongame species, mostly in response to public demands for greater equity of management for game and nongame species on public lands. The demand for greater nongame research has also resulted in a tendency to depart from single-species management. The large number of nongame species has caused nongame management to focus on the community and bioregion levels. Responsible agencies are searching for management techniques that will maximize the diversity of nongame communities and benefit as many game species as possible. Nevertheless, single-species management remains important to game species and to those species that are rare and/or endangered.

\section{REFERENCES}

Landers, J. L., and A. S. Johnson. 1980. “Trends in wildlife habitat research.” In Proceedings, Annual Conference of the Southeastern Association of Fish \& Wildlife Agencies. Wildlife Resources Agency, Nashville, TN. 



\section{APPENDIX G}

\section{WILDLIFE MANAGEMENT ACTIVITIES FISCAL YEAR 1983}



Wildlife studies on the Oak Ridge Reservation (ORR) have been aimed toward a better understanding of the ecological relationships of a species with habitat, information on population sizes and health, baseline data, and impacts of various activities. These studies have been done through the Facilities and Operations Directorate and the Environmental Sciences Division (ESD) in coordination with the Tennessee Wildlife Resources Agency (TWRA). Wildlife-related projects over the last three decades have included those related to the following:

- $\quad$ white-tailed deer

— statistics on deer/vehicle collisions

— aging techniques to determine the structure of the population (Tennessee Tech graduate student project) (Mitchell 1989)

- hunt data for sex, age, location killed, liver, bone, radioactivity levels, chronic wasting disease, Lyme disease (ticks), and abosomal parasite counts

- $\quad$ wild turkey

— reintroduction of turkeys to the ORR

- radio-tracking to determine habitat preferences (with University of Tennessee researcher)

— recording of poult sightings and deaths

— trapping and removal for reintroduction at other Tennessee sites

- $\quad$ nongame species

— radio-tracking of coyote

— coyote history, abundance, distribution

— comparison of songbirds in different pine plantations (Hardy 1991)

— ecology of gray foxes (Greenberg, Pelton, and Parr 1988)

- bat surveys

— Partners in Flight bird surveys

- remediation-effects-related research

— turtle, fish, benthos invertebrates

- contaminant-transport-related research

- deer (Garten and Lomax 1987)

— waterfowl

\section{SUMMARY OF MANAGEMENT ACTIVITIES: FY 1983 TO FY 2006}

Specific projects to be implemented during the period from fiscal year (FY) 1983 to FY 1987 were summarized in the 1984 Wildlife Management Plan (Kitchings and Story 1984). Many of these activities were initiated, but others were not because of changes in the priorities of the program. The summary below highlights the activities of the wildlife program from FY 1983 to FY 2006. (The FY begins October 1st and continues through September 30th.)

\section{FY 1983}

- Evaluation of wildlife management needs and development of a plan for the ORR

\section{FY 1984}

- Publication of the original wildlife management plan for the ORR 


\section{FY 1985}

- Cooperative agreement between Department of Energy (DOE) and TWRA designating ORR as Wildlife Management Area (November 30, 1984)

- Location of TWRA wildlife manager on-site

- Mast surveys done for ORR (data used in regional statistics)

- Removal of geese from contaminated ponds

\section{FY 1986}

- Initiation of public deer hunting (winter 1985)

- Release of first wild turkeys on ORR

- Study of deer-age structure on ORR from hunt data by Tennessee Tech student

- Mast surveys on ORR

\section{FY 1987}

- Second release of wild turkeys on ORR

- Initiation of turkey radio-tracking for habitat-preference information

- Placement of wood-duck nesting boxes on ORR

- Work with ESD on study identifying sources of contamination for deer

- Continuation of mast surveys

- Continuation of study on deer-age structure from hunt data

- Annual public deer hunt (first effect of hunts reflected in lower deer/vehicle collision data for year)

\section{FY 1988}

- $\quad$ Radio-tracking of turkeys released in 1987

- Placement of wood-duck nesting boxes on ORR

- Establishment of osprey nesting platforms

- Studies of waterfowl contamination/transport

- Canada goose roundup and banding for identification 
- Annual mast survey on ORR

- Annual public deer hunt

- Trapping and removal of wild turkeys to stock other east Tennessee areas

\section{FY 1989}

- Establishment of additional osprey nesting platforms

- Placement of wood-duck nesting boxes on ORR

- Continuation of waterfowl contamination study

- Canada goose roundup with banding and collaring

- Annual mast survey

- Annual public deer hunt

- Implementation of plans to keep waterfowl off contaminated ponds

- Trapping and removal of wild turkeys to stock other areas in east Tennessee

\section{FY 1990}

- Extension of cooperative agreement between DOE and TWRA for wildlife management on ORR

- Reevaluation from a safety standpoint of areas on ORR open to hunters

- Banding of first osprey young on ORR

- Placement of wood-duck boxes on ORR

- Continuation of osprey restoration program

- Canada goose roundup

- Annual mast survey

- Annual public deer hunt

- Trapping and removal of wild turkeys to stock other areas in east Tennessee

\section{FY 1991}

- Update of wildlife management plan

- Computerization of historical white-tailed deer information on database (20 years of data) 
- Preparation of updated document on ORR deer statistics

- Annual public deer hunts

- Feasibility study for reintroduction of bald eagles on ORR

- Canada goose roundup

- Annual mast survey

- Continuation of osprey restoration program

- Trapping and removal of wild turkeys to stock other areas in East Tennessee

- Placement of additional wood-duck boxes

\section{FY 1992}

- Initiation of discussions regarding a possible eagle hacking program for restoration of species on ORR

- Annual public deer hunts

- Canada goose roundup

- Annual mast survey

- Continuation of osprey restoration program

- Trapping and removal of wild turkeys to stock other areas in east Tennessee

- Continuation of wood-duck-habitat establishment program

- Evaluation of impacts of discontinuation of forest management program on species and habitat diversity

- Great blue heron contamination studies

\section{FY 1993}

- Continuation of bald eagle research and consideration of hacking program

- Annual public deer hunts

- Canada goose roundup

- Annual mast survey

- Continuation of osprey restoration program 
- Trapping and removal of wild turkeys to stock other areas in east Tennessee

- Continuation of wood-duck establishment program

- Evaluation of need for selective forest management and recommendations

- Evaluation of the impact of forest fragmentation on wildlife species

\section{FY 1994}

- Continuation of bald eagle research and consideration of hacking program

- Annual public deer hunts

- Canada goose roundup

- Annual mast survey

- Continuation of osprey restoration program

- Removal of wild turkeys to stock other areas in East Tennessee

- Continuation of wood-duck establishment program

- Implementation of recommendations from selective forest management study and forest fragmentation study to increase species diversity

\section{FY 1995}

- Continuation of bald eagle research and consideration of hacking program

- Annual public deer hunts

- Canada goose roundup

- Annual mast survey

- Continuation of osprey restoration program

- Continuation of wood-duck establishment program

- $\quad$ Selective forest management for species diversity

\section{FY 1996}

- Annual public deer hunts

- Annual public turkey hunts

- Annual goose roundup 


\section{FY 1997}

- Annual public deer hunts

- Annual public turkey hunts

- Annual goose roundup

- Surveys of bat populations using mist nets

\section{FY 1998}

- Annual public deer hunts

- Annual public turkey hunts

- Annual goose roundup

\section{FY 1999}

- Annual public deer hunts

- Annual public turkey hunts

- Annual goose roundup

\section{FY 2000}

- Annual public deer hunts

- Annual public turkey hunts

- Annual goose roundup

\section{FY 2001}

- Annual public turkey hunts

- Annual goose roundup

\section{FY 2002}

- Annual public deer hunts

- Annual goose roundup 


\section{FY 2003}

- Annual public deer hunts

- Annual public turkey hunts

- Annual goose roundup

- Surveys of bat populations using mist nets and the Anabat acoustical identification system

\section{FY 2004}

- Annual public deer hunts

- Annual public turkey hunts

- Annual goose roundup

- Surveys of bat populations using the Anabat acoustical identification system

\section{FY 2005}

- Annual public deer hunts

- Annual public turkey hunts

- Annual goose roundup

- Relocation of 117 ORR Canada geese to the to the Hiwassee Wildlife Refuge and to Chota, Tennessee

- Initiation of Canada goose egg addling/nest destruction program (60 eggs addled/oiled)

\section{FY 2006}

- Annual public deer hunts

- Annual public turkey hunts

- Public goose hunts at the Three Bend Scenic and Wildlife Management Refuge Area

- Annual goose roundup

- Relocation of 200 ORR Canada geese to Hiwassee Refuge and Chota, Tennessee

- Continuation of Canada goose egg addling/nest destruction program (67 eggs addled/oiled)

- Surveys of bat populations using the Anabat acoustical identification system and mist nets 


\section{REFERENCES}

Garten, C. T., Jr., and R. D. Lomax. 1987. Strontium-90 Contamination in Vegetation from Radioactive Waste Seepage Areas at ORNL, and Theoretical Calculations of SR-90 Accumulation by Deer. ORNL/TM-10453, Oak Ridge National Laboratory, Oak Ridge, TN.

Greenberg, C. H., M. R. Pelton, and P. D. Parr. 1988. Gray Fox Ecology in the Oak Ridge National Environmental Research Park: Food Habits, Home Range and Habitat Use. ORNL/NERP-3, Oak Ridge National Laboratory, Oak Ridge, TN.

Hardy, C. 1991. “A Comparison of Bird Communities in Loblolly vs. White Pine Plantations on the Oak Ridge National Environmental Research Park.” Thesis, University of Tennessee, Knoxville

Kitchings, J. T., and J. D. Story. 1984. Resource Management Plan for the Oak Ridge Reservation, Volume 16: Wildlife Management. ORNL/TM-6026, Oak Ridge National Laboratory, Oak Ridge, TN.

Mitchell, C. M. 1989. "Influence of Either-Sex Harvest on the Age and Sex Structure of White-Tailed Deer on Oak Ridge Wildlife Management Area, Tennessee.” Thesis, Tennessee Technological University, Cookeville, TN. 


\section{INTERNAL DISTRIBUTION}

$\begin{array}{llll}\text { 1. } & \text { W. M. Belvin (DOE at ORNL) } & 40-49 . & \text { P. D. Parr } \\ \text { 2. } & \text { H. L. Debban } & 50-54 . & \text { J. D. Peebles (BWXT Y-12) } \\ \text { 3. } & \text { J. W. Evans } & 55 . & \text { M. J. Peterson } \\ 4-28 . & \text { N. R. Giffen } & 56 . & \text { L. L. Radcliffe (DOE at ORNL) } \\ \text { 29. } & \text { T. J. Harrison } & 57 . & \text { E. L. Ryan } \\ \text { 30. } & \text { G. K. Jacobs } & 58 . & \text { J. W. Smith } \\ \text { 31. } & \text { R. C. Mann } & 59 . & \text { R. R. Smith } \\ \text { 32. } & \text { T. Mason } & 60-84 . & \text { C. A. Spoons (DOE at ORO) } \\ \text { 33-37. } & \text { M. J. McNutt (Bechtel Jacobs) } & 85 . & \text { J. E. Stone } \\ \text { 38. } & \text { J. O. Moore (DOE at ORNL) } & 86 . & \text { S. H. Young } \\ \text { 39. } & \text { D. G. Page (DOE at ORO) } & 87 . & \text { ORNL Office of Technical Information and } \\ & & & \text { Classification }\end{array}$


